Benefits of Empire? Capital Market Integration North and South of the Alps, $1350-1800$

Accepted for publication in Journal of Economic History (09/01/2018)

David Chilosi is Assistant Professor, Faculty of Economics and Business, University of Groningen, Nettelbosje 2, 9747 AE Groningen, The Netherlands. Email: d.chilosi@rug.nl

Max-Stephan Schulze is Professor of Economic History, Department of Economic History, London School of Economics \& Political Science, Houghton Street, London WC2A 2AE, United Kingdom. Email: m.s.schulze@1se.ac.uk

Oliver Volckart is Professor of Economic History, Department of Economic History, London School of Economics \& Political Science, Houghton Street, London WC2A 2AE, United Kingdom. Email: $\underline{\text { o.j.volckart@1se.ac.uk }}$

Acknowledgements:

We gratefully acknowledge the financial support by the Leverhulme Trust (grant RPG-133). Particular thanks are due to Alexandra Sapoznik and Angela Ling Huang for collecting and preparing the archival data. We also thank three anonymous referees, the editor of the Journal and the participants at the EHES Conference in Pisa, the Symposium in Business and Economic History in Lisbon, the Berlin Colloquium in Economic History at Humboldt University and the Economic History Seminar at the University of Vienna for helpful comments, suggestions and criticism. 
Benefits of Empire? Capital Market Integration North and South of the Alps, $1350-1800$

\begin{abstract}
This paper addresses two questions. First, when and to what extent did capital markets integrate north and south of the Alps? Second, how mobile was capital? Analysing a unique new dataset on pre-modern urban annuities, we find that northern markets were consistently better integrated than Italian markets. Long-term integration was driven by initially peripheral places in the Netherlands and Upper Germany integrating with the rest of the Holy Roman Empire where the distance and volume of inter-urban investments grew primarily in the sixteenth century. The institutions of the Empire contributed to stronger market integration north of the Alps.
\end{abstract}

\title{
Introduction
}

Historians of premodern Europe agree that Central Europe was financially far less advanced than the Italian city states that were leading in financial innovation at least up to the seventeenth century. It was in Italy where modern commercial loans emerged first and governments first developed a system of municipally funded debts (Day 1987; Sylla 2002: 82; Munro 2003, pp. 514-16; Denzel 2008, pp. 51-53). The present article compares the integration of capital markets in this financially sophisticated region with markets in Central Europe. The focus is on one specific type of market for capital, i.e. the market for urban annuities which is particularly well documented.

Annuity markets have been studied from a variety of perspectives. One strand of the historiography is concerned with the social background of the buyers of annuities and the role 
such instruments played in constitutional development and public finance (Gabrielsson 1971; Sprandel 1971; Rosen 1978; Gilomen 1982; Alter and Riley 1986; Brown et al. 2001; Tracy 2003; Poitras 2006; Zuiderduijn 2009; van der Heijden 2006). This literature explores an issue closely linked to our present concerns: the geographical origin of investors. Several authors stress that in Italy, unlike Northern Europe, most urban bonds were owned by locals (Molho 1995, pp. 107-09; Pezzolo 2005, pp. 156-58; Zuiderduijn 2009, pp. 262-64).

Another strand of the literature is primarily concerned with the factors determining the level of interest rates and its change over time. Within this particular historiography one can distinguish two lines of argument: Some authors highlight how political systems like feudalism (Chilosi 2014) or institutions such as representative assemblies (Stasavage 2011, pp. 154-55) influenced capital costs; others emphasize the role played by the supply of capital and the development of secondary markets (Epstein 2000, pp. 19-24; Gelderblom and Jonker 2004, 2011).

There is a third, and growing, strand of research that speaks directly to the issue of this paper, namely capital market integration.

${ }^{1}$ Luciano Pezzolo and Guiseppe Tattara (2008), for example, examined how the exchange fairs of Bisenzone around 1600 fostered inter-urban arbitrage and financial market integration. Genoese bankers used the fairs to raise money for the Spanish crown, developing financial techniques and a network that reduced the risk of lending to fund Spanish long-term debts via short-term loans. By contrast, Carlos Álvarez-Nogal's (2009) study of urban public debts in Castile found no evidence of integration across the annuity markets of Burgos, Cadiz and Murcia between 1540 and 1740. Most recently Wolfgang Keller et al. (2016) drawing on interest rates imputed from grain storage data, compared Chinese and British capital markets in the late eighteenth and nineteenth centuries. They found not only that the costs of capital in 
Britain were on average lower than in China, but also that British capital markets were better integrated.

In this paper we measure and document the extent, timing and spatial spread of premodern capital market integration. We employ Maurice Obstfeld and Alan Taylor's (2004) well-tried approach and examine, first, patterns of convergence in interest rates (here: yields of urban annuities) and, second, inter-city capital flows. The study draws on a new, unique dataset of about 29,000 individual interest rate observations from more than 100 cities over a period of almost 500 years. We consider markets from across the Holy Roman Empire north of the Alps and from Italy. ${ }^{2}$ The earliest observations in the sample are from the fourteenth century, with the analysis closing at around 1800. We ask to what extent urban capital markets integrated in the long run and how mobile capital was between cities.

The interest rates used here derive from the prices of life and heritable annuities sold by town councils. In the Empire, these instruments were secured against real estate owned by the town or, more rarely, against its regular revenues. Buyers of such securities paid a sum of money in return for an annual interest payment. If a town defaulted, the courts protected the annuity holders' right to seize the real estate that served as collateral. Life annuities and heritable annuities differed in that life annuities were typically paid until the purchaser died. By contrast, heritable annuities were - in principle, at least - paid in eternity and could be bequeathed (Baum 1985, p. 25).

A few surviving accounts allow gauging the importance of such urban debts. In Nuremberg in the 1430 s, for example, newly raised loans reached up to 55 per cent of the total annual income of the town. For fifteenth-century Munich values of up to 25 per cent, and for sixteenth-century Schwäbisch Hall values up to 62 per cent have been calculated (Fuhrmann 2003, pp. 4-12). By the end of the early modern age, most Free Imperial Cities were heavily indebted. Those in South Germany commonly had to earmark more than half of 
their revenues for servicing their liabilities (Quarthal 1991, p. 223). Territorial towns, i.e. those under the authority of a prince, depended less on deficit finance, as loans had to be increasingly approved by their rulers from about the mid-seventeenth century (Kern, 2000; Fuhrmann 2014, pp.188, 195).

Italian annuities developed in two phases. From the twelfth to the fifteenth centuries, many securities, known as forced loans, were forcibly allocated to the local well-to-do, with Genoa, Florence and Venice among the cities that issued such securities (Pezzolo 2005). From the sixteenth century, urban debts spread across the peninsula and voluntary lending became the norm (Pezzolo 1995). Urban authorities typically allocated specific revenues to servicing their debts. While fiscal decentralisation was as common in Italy as in the Empire, estimating the size of debt is possible for capital cities where urban and regional state finances overlapped. For example, in about 1500 the Republic of Genoa's stock of debt was 35 times the size of its annual revenues. This was an extreme case. In Florence and Venice the corresponding figure was about one fourth. In the seventeenth century, other cities caught up with the financial pioneers, with their debts rapidly expanding in the face of stagnating revenues. Thus, by 1700, Venice and Papal Rome had accumulated a stock of debt equivalent to, respectively, 15 and 20 times annual revenues. These were very high debts indeed with the stock of per capita debt equivalent to the annual costs of feeding, clothing and housing around two people. Those of Naples and Milan were not far behind (cf. Chilosi 2014, pp. 897-98).

Comparing the Empire and Italy is exceptionally fruitful. Italy gave birth to a large number of financial innovations that until the seventeenth century earned it the reputation as the financially most advanced part of Europe. By contrast, the historiography regards Germany as backward (de Vries 1976, p. 221; Denzel 2008, pp. 105-06, 121). Politically, the Empire and Italy give a superficially similar impression of having been fragmented. 
However, unlike Italy, the Empire had an overarching constitution. This constitution applied neither to the Imperial fiefs in Italy nor to the rest of the peninsula (Schmidt 2011, p. 46). Moreover, in Italy, alternative supra-urban organizations such as the Lombard League were defunct already by the fourteenth century, whereas the Empire's constitution continued to be supplemented by urban and other leagues far into the early modern age (Spruyt 1994, pp.10911; Distler 2006).

Our results suggest that over the whole period markets were better integrated north of the Alps than in financially more developed Italy. Indeed, in the early modern era, interest rate differentials narrowed only in the Empire. Further, north of the Alps both the distance and volume of investments grew at the same time as the yield differentials between distant markets declined. In the Empire, capital markets had a number of centres. The long-term erosion of interest differentials between them was mainly driven by convergence of initially peripheral markets in the Netherlands and Upper Germany with the rest.

\section{Sources and Data}

Most data used here were collected from a large number of archives which are listed in detail in Online Appendix A. In Table 1 we delineate the main types of sources. Letters contain the most comprehensive information. They generally give the contract, and margin and dorsal notes sometimes give additional information, e.g. on later changes and redemptions. Ledgers, including all books and documents kept to administer urban annuities, are the most heterogeneous type of source. At best, they record all sold annuities, briefly listing the conditions of the contract, as well as transfers, conversions and redemptions (e.g. the Nuremberg ledgers). However, most ledgers contain only partial information on the contract and its history. Pay-out ledgers, for example, sometimes omit the original interest rate but record a later conversion. In a few cases, we had to infer the date of the conversion by 
checking whether different types of sources were consistent with each other. Urban accounts record sold annuities as part of the revenues of a town. As several branches of urban administration could sell annuities, the main accounts (that we use predominantly) do not necessarily document all sales in a year. They only summarise the contracts, stating the name of the buyer, the capital and pay-out or interest rate, sometimes the date, but mostly only the fiscal year. In such cases we assumed that the annuity was sold in the first calendar year (e.g. when the fiscal year was $1525 / 26$, we assumed the sale to have taken place in 1525). Data from edicts that reported the official rate and (in varying levels of detail) the conditions of purchase were included from Northern France, the Netherlands and Italy only.

< Table 1 about here >

For Germany, the data come from actual sales of annuities - i.e. we exclude interest rates stipulated in edicts or similar sources. The data refer to primary yields which are much better documented than those on secondary markets. Where evidence on interest rates in secondary markets exists, it shows yields close to those on primary markets. ${ }^{3}$ Note that German urban authorities sold annuities continuously, that is not only in times of fiscal need or when there was a particularly strong demand by prospective buyers. For non-German markets in the Empire, for example Dutch or Flemish, the analysis includes rates determined by law and published in edicts. In Lille and Amsterdam, where it is possible to compare such rates with those paid on the primary market, both match. ${ }^{4}$

The data for Italy come in two forms. First, for the period before 1493 we use secondary market rates on forced loans, which until this point dominated urban debts. As such forced loans were riskier than those purchased voluntarily, differentials between forced loans' rates and their secondary market rates were far larger than in the case of rents issued on 'open' primary markets (Chilosi 2014, pp. 889-91, 2015, Section 5). Second, from the sixteenth century onwards, i.e. after forced loans had fallen out of use and 'open' primary markets 
emerged, our Italian interest rate data mainly refer to official rather than market rates.

However, where primary market rates are available the official rates were typically close to them. Since market yields tended to magnify differences in the return between safe and risky securities (Chilosi 2014, p. 892), using mostly official rates biases the analysis against our finding below that Italian markets were relatively weakly integrated. ${ }^{5}$

With few exceptions, which we exclude from the analysis, the prices of urban life and heritable annuities were not related to the age or health or any other biological characteristics of the buyers or those in whose name an annuity was taken out. Hence, the ratio between the yearly pay-out and the purchase price equals the interest rate. ${ }^{6}$ The analysis uses nominal rather than real (i.e. deflated) rates for three reasons. First, the available evidence suggests that differences in long-run inflation rates between markets were small (Allen 2001, online database ${ }^{7}$ Malanima 2002, Appendix). In the given context, it is these long-term rates that matter since the focus here is on securities with long-term maturities. Second, likely small differences between local inflation rates can be estimated only imprecisely because there are few cities where sufficiently detailed price indices are available. Third, and most importantly, the information needed to anticipate price changes over the long term was not readily available to the investors (Gilomen 1984, p. 195). When deciding where and at what interest to invest their capital, pre-modern inverstors had little choice but to use nominal rather than real rates (Chilosi 2014, p. 903).

Sometimes authorities taxed annuities or offered benefits to buyers. Within the Empire, it is only in Nuremberg and Brunswick and in selected periods that the evidence allows estimating what difference this made. ${ }^{8}$ We compare 186 rates on such annuities from between 1396 and 1590 and found that tax-free rates differed on average only by 0.37 percentage points from others. In Italy, some of the forced loans in Venice and annuities sold in Genoa 
were taxed. Generally, we used the return net of tax when available or else we assume that the pay-out was not affected by taxes or benefits.

The difference between yields on equally risky securities cannot exceed inter-urban transaction costs for long periods of time because arbitrage will trigger adjustment, with capital flowing from where it is relatively cheap to where it is relatively costly. In consequence, differences in yields shrink until they are at the level of or lower than transaction costs. However, these costs are not the only determinant of yield differentials. Similar conditions of supply and demand can produce similar interest rates even in the absence of arbitrage. We therefore also analyse inter-urban capital flows. Such flows highlight that cities within the Empire were linked through fairly dense ties. Thus, the twelve best-covered cities in the sample show a network density (the proportion of actual to potential links) of 42 per cent. ${ }^{9}$ This is a much higher value than that for the mid-eighteenth century European money market (12 per cent, Flandreau et al. 2009, p. 160) and roughly matches that existing between nation-states in today's bond market (57 per cent, Schiavo et al. 2010, p. 392).

Moreover, inter-urban differences in yields may reflect not only transaction costs between markets but also differences in risk of default (non-payment or falling into arrears). However, if cities discriminated between domestic and 'foreign' (in its premodern sense, cf. Schultze 1908, p. 77) investors, exposing them to different risks, as was often the case in Italy, then the differences between their risk premia did indeed become part of inter-urban transaction costs, thus affecting the measured extent of integration.

The analysis uses yearly means as there are only few cases where the date of a transaction can be identified with greater than yearly precision. Altogether, there are 5,040 yearly means for heritable and 1,520 for life annuities. While in the very early stages of development life annuities were the more important instrument, over time they became less 
popular. Possibly this reflected a learning process on the part of the sellers: Heritable annuities did not require the authorities to periodically check that the beneficiary was still alive and, therefore, implied lower administrative costs than life annuities. Further, life annuities were potentially bought on behalf of young children, implying a higher return to the beneficiaries and higher costs to the issuer. The data from the Empire allow analysing differentials between local yields from the mid-fourteenth century. For Italy, where secondary market yields on forced loans are available only for Florence, Genoa and Venice, the number of pre-sixteenth-century observations is so small that for this period the analysis cannot be more than exploratory. Up to the mid-seventeenth century the number of observations increases. There are fewer surviving data from the Empire thereafter. Following the Peace of Westphalia, many cities lost their fiscal autonomy and ceased raising debts. Figure 1 ( $a$ and $b$ ) shows the geographical distribution of observations of yearly means.

$<$ Figure 1 about here>

The interest rates are from 101 cities, 72 of which are located north of the Alps and 30 in Italy. ${ }^{10}$ While the coverage is uneven, our archival research extends far beyond what was available in previous studies of urban annuities or premodern financial integration in Europe. The north of the Empire is particularly well-covered, as are Central and Northern Italy. Figure 1a also shows that life annuities were clearly much less common in Italy than north of the Alps. For this reason, life annuities are examined only for the whole sample and the northern sub-sample.

Figure 2 shows how the nominal yield on heritable annuities, including forced loans in Italy before 1493 , developed north and south of the Alps. ${ }^{11}$

$<$ Figure 2 about here> 
In the long run nominal interest rates in the Empire declined, though in contrast to what prior research implied (Homer and Sylla 2005, pp. 135, 153, 176), their fall was not steady. Two periods of decline stand out: the early fourteenth to the early fifteenth and the second half of the seventeenth centuries. In between and after these periods rates stagnated. Italian forced loans, whose yields on the secondary market had often been exceptionally high and volatile, disappeared around 1500. Thereafter, Italian yields on securities sold on the primary market fell continuously to the late eighteenth century. Despite the country's precocious financial development in the late Middle Ages, yields in Italy were initially much higher than north of the Alps. However, they fell to values lower than those in the Empire in the mid-seventeenth century and from then on stayed slightly lower until the end of the period analysed here.

\section{Integration Trends: North versus South}

The coefficient of variation is a standard measure of price or interest rate dispersion: The smaller it is, the more alike were local interest rates and the greater the level of integration. However, as the coefficient is affected by changes in the sample's composition of markets, gaps in the interest rate series may introduce a bias. To address this issue, we use city fixed effects and regress the absolute value of the natural logarithm of the ratio between the interest rate in each market and the average interest rate on a time trend:

$$
\operatorname{abs}\left[\ln \left(\frac{i_{i t}}{\bar{l}_{t}}\right)\right]=\alpha_{i}+\beta y e a r+u_{i t}(1)
$$

where $a b s$ stands for absolute value, $\ln$ is the natural logarithm operator, $i_{i t}$ is the interest rate in place $i$ and year $t, \bar{l}_{t}$ is the sample cross-sectional average interest rate in year $t, \alpha_{i}$ is a place-specific fixed effect, $\beta$ is the yearly rate of change and $u_{i t}$ is an error term.

The results (Table 2, columns 3 and 4) show that the differentials were much larger in Italy than in the Empire both at the beginning and at the end of our period. This holds irrespective 
of whether forced loans traded on the secondary market in late medieval Italy are included. Only if such forced loans are included do Italian markets display a significant trend in longrun interest rate convergence. In other words, from the sixteenth century, when a primary market in annuities developed, interest rates in Italy did not converge any further. By contrast, the results on yearly rates of change and the associated cumulated changes indicate a long-term advance in integration north of the Alps (Table 2, columns 5 and 6).

$<$ Table 2 about here>

Such long-term trends may obscure non-linear patterns of convergence and divergence. To examine such patterns, we use again fixed effects panel analysis of the dispersion around the mean, but now with 10-year dummies rather than a time trend (cf. Bateman 2011):

$$
\operatorname{abs}\left[\ln \left(\frac{i_{i t}}{\bar{l}_{t}}\right)\right]=\alpha_{i}+\sum_{d=1350-1359}^{1790-1799} \beta_{d} \text { Decade }_{d}+u_{i t}(2)
$$

where $\beta_{d}$ denotes the rate of change in the gap between the local and the sample average interest rate in decade $d$, otherwise the notation is as in equation (1).

As the analysis requires a large sample, we consider heritable annuities only (Figure 3). ${ }^{12}$

$<$ Figure 3 about here>

Interest rates in Italy were much more dispersed than in the Empire. For the late Middle Ages, this appears to have been due to the dominance of forced loans. Once an open market for annuities had developed, interest differentials moved closer to those in the Empire. However, not only were they still larger than north of the Alps, they also fluctuated far more strongly throughout the whole period under review. In terms of dispersion, northern capital markets were clearly better integrated than those in the supposedly more developed south. 
Recent research has shown that in Italy differences between local risk-levels helped keeping differentials large. Apart from forced loans in the late Middle Ages, securities issued in the early modern Spanish territories (Milan, Naples and Sicily) were particularly risky (Chilosi 2014, pp. 890, 900). Still, even if observations from the Spanish possessions are excluded, differentials in Italy remain wider than in the Empire. The difference is especially startling considering that the average distance of 286 kilometres between between the Italian cities is smaller than that between the sample cities north of the Alps (379 kilometres).

Examining where the owners of the debts lived confirms that the Empire was better integrated than Italy. In the Middle Ages, securities issued by Italian city-states were mostly held locally. Capital flows between Italian cities did intensify in the early modern era, but most bonds still remained in local hands. The Italian city where foreigners owned the greatest share of the debt was probably Venice. By the later seventeenth century, about one-third of its debt was owned by people from outside the Republic, mostly from Genoa (Felloni 1971, passim; Masini 2007, pp. 205-07; Stumpo 2007, pp. 149-51). By contrast, in Flanders, Holland and Germany a large part of the urban debt, half or more, was owned by non-locals even at the very beginning of the period under review (Fryde and Fryde 1963, pp. 528-30, 540, 545, 547, 553; Munro 2007, pp. 10, 21-22; Zuijderduin 2009, pp. 178-79). In the Empire inter-urban capital flows further intensified over time.

\section{Capital Flows and Distance}

How large were the distances over which investors in the Empire placed their capital, and how did these distances and the invested sums change over time? For 52 markets north of the Alps, the sources contain information on the origin of investors from other places. After excluding trivial links with markets within their hinterland, ${ }^{13}$ we retain 4,541 observations of inter-city investments across 915 city pairs. Comparing investments from different periods 
requires converting the invested sums into a constant measure. We use the cost of a yearly 'respectable' consumption basket. ${ }^{14}$ Excluding those cases where missing capital or coinage data prevented conversion, the analysis builds on 4,095 investment observations. As a first step to assess how capital flows evolved, we investigate trends in the distance and volume of investments. As before, to control for changes in the composition of the sample over time we run fixed-effect panel regressions of the natural logarithm of the yearly means against a timetrend:

$$
\ln \left(y_{i t}\right)=\alpha_{i}+\beta y e a r+u_{i t}(3)
$$

where $y_{i t}$ is the yearly mean of the dependent variable of interest (capital invested or distance between places) in place $i$ in year $t, \alpha_{i}$ is an importer-specific fixed effect and $\beta$ is the yearly rate of change; $u_{i t}$ is an error term.

$<$ Table 3 about here>

In the long run the distance and volume of investments grew significantly: With distance increasing from 47 to 116 kilometres and capital invested rising from 31 to 87 consumption baskets (Table 3, columns 5 and 6), the average values are more than twice as large at the end of the period as at its beginning. This supports the finding that the Empire's capital markets became increasingly integrated. While most investors placed their capital relatively close to home, the sums in question were large. On average and at the prevailing interest rates (see Figure 2), the yearly return on the sums invested in heritable annuities was sufficient to feed, clothe and house about three people, i.e. a small family.

To gauge when the distance and volume of inter-city investments grew, we regress their means against 50-years dummies over the period 1350-1699 (there are not enough eighteenth century observations to produce reliable estimates): ${ }^{15}$ 


$$
\ln \left(y_{i t}\right)=\alpha_{i}+\sum_{f=1350-1399}^{1650-1699} \beta_{f} \text { Fifty }_{f}+u_{i t}(4)
$$

where $\beta_{f}$ is the rate of change in the dependent variable of interest ( $y_{i t}$ : capital invested or distance between places) in the fifty-year period $f$, otherwise the notation is as in equation (3). The trends obtained are compared with the inverted trend of the interest-rate differentials (heritable annuities) within the Empire, where a higher value signals increased capital market integration (Figure 4).

$<$ Figure 4 about here $>$

From the early sixteenth to the mid-seventeenth century, the increase in integration (here shown as a rise in the inverted log interest-rate ratio, right hand axis) was closely associated with growth in both invested sums and distance of investments (left hand axis). In the second half of the seventeenth century, however, the capital figures and the differentials suggest disintegration while the distance measure does not. This is probably an outcome of the spatially uneven effects of the Thirty-Years-War. The demand for capital grew relative to its supply as the need to finance post-war reconstruction led to a decline in sums invested in the annuity market. At the same time, distances over which capital was placed continued to increase as urban authorities - in the face of diminished local supply - were seeking to attract capital from farther away, i.e. areas less affected by the war. ${ }^{16}$

The question is how the reach of the market expanded over the long term. We use 1520 as a suitable cut-off point because it marks the start of the sixteenth-century spurt in interest rate convergence and allows splitting the sample into two similarly-sized sub-samples. ${ }^{17}$ Both before and after 1520, most capital was invested within a radius of 200 kilometres and sums rarely exceeded 200 consumption baskets, which corresponds, for example, to 3,411 Lübeck marks in 1520. However, the reach of the market increased at the high margin: from the 
sixteenth century, investment gained previously unattained sizes and distances which drove up the average values of investments. ${ }^{18}$

Did long-distance investment also drive interest rate convergence ${ }^{19}$ Since we find that the frequency of inter-city investments drops sharply beyond c. 200 kilometres, this makes an appropriate cut-off point for comparing long-term trends. We use fixed effects panel regression of pairwise differentials on time:

$$
a b s\left[\ln \left(\frac{i_{i t}}{i_{j t}}\right)\right]=\alpha_{i}+\beta y e a r+u_{i t}(5)
$$

where the notation is equivalent to that of equation (1).

Table 4 shows the results.

<Table 4 about here>

The highly significant yearly rates of change and associated cumulated changes (Table 4, columns 3 and 6) indicate that long-distance convergence played the key role, advancing almost twice as fast as local convergence. By the end of the period, pairwise differentials between distant places were on average almost as small as those between close markets (Table 4, column 5).

To show when differentials between more distant places shrank, we compare the pairwise differentials across distance groups over consecutive 10-year periods and compute panel trends:

$$
a b s\left[\ln \left(\frac{i_{i t}}{i_{j t}}\right)\right]=\alpha_{i}+\sum_{d=1320-1329}^{1800-1809} \beta_{d} \text { Decade }_{d}+u_{i t}(6)
$$

where the notation is equivalent to that in equation (2).

$<$ Figure 5 about here $>$ 
Figure 5 shows the estimated trend values. The results are fully in line with those of the earlier analysis. Short-distance convergence $(<200 \mathrm{~km})$ advanced significantly from the early fifteenth to the mid-sixteenth centuries. Long-distance convergence began several decades later: Differentials between places over 200 kilometres apart declined from about 1500 to 1630. Since the early seventeenth century, interest rates differentials varied little between both distance groups, i.e. by about 10 to 15 per cent on average. In other words, given costs of capital of about 4 per cent, we are looking at interest rate differentials of half a percentage point, which suggests a capital market that was well-integrated by any standard.

\section{Regional Integration in the Empire}

How clustered were capital markets north of the Alps - or which cities were linked by particularly strong capital flows? We investigate these questions first and then use the insights thus gained to divide our sample and study how capital market integration evolved between and within clusters in the Empire.

To identify clusters of cities, we rely on the model developed by Michael Schweinberger and Tom Snijders (2003). Their technique allows detecting such clusters across various levels of capital flow intensity, defined in a descending order where level 1 is the highest. The likelihood that all the actual links between cities in the sample are recorded does increase with the number of observations from each capital-importing city. However, the fewer wellrecorded cities are included, the smaller is the geographical area covered. Concentrating on the 28 cities with at least 10 observations on capital imports is a compromise between the desire to include as many markets and as wide an area as possible and the need to focus on those cities which are sufficiently well-documented. Sample bias is addressed by estimating the capital flows that would be observed if all the linked cities had the same number of 
observations on capital imports. The measure of capital flow intensity is an index that ranges from 0 to 1 (see Online Appendix B for technical details). Figure 6 shows the clusters.

< Figure 6 about here>

Capital flows were exceptionally strong between Lübeck and Lüneburg. These are the only cities where we observe the highest level of capital flow intensity. Already at the next lower level, intensity drops by two thirds (from 1 to 0.364 ). At this level, we find two clusters: one is an expanded group in Lower Saxony (Hamburg and Brunswick, together with Lübeck and Lüneburg); the other is the Frankfurt-Mainz pair in Hesse. Expected capital flows at the third level remain relatively high (0.15). Here, Bremen, Hanover and Hildesheim join the cluster in Lower Saxony. Worms becomes part of the Hesse cluster that at Level 2 was formed by Frankfurt and Mainz only. Moreover, at the third level a Breisgau cluster (Basel, Colmar and Freiburg), an Upper Germany cluster (Augsburg, Munich, Nuremberg), a cluster in Upper Saxony (Erfurt, Leipzig, Halle) and another in Westphalia (Münster, Wesel) emerge. The fourth level, not shown in Figure 6, contains all 28 cities examined but is characterised by very weak capital flows $(0.009){ }^{20}$

These findings agree with our results on the role of distance. All cities with strong capital flow links between them were geographically relatively close, with clusters developing around financial or commercial centres such as Frankfurt, Leipzig, Nuremberg and Lübeck. ${ }^{21}$ Outside these clusters, capital flows tended to be much smaller. One reason for this difference may be information flows that, though not directly related to annuities, made for easier intercity investment. The relation between Lüneburg - a centre of the production of salt - and Lübeck - from where the salt was distributed across the Baltic - is a case in point: The cluster in Lower Saxony reached particularly high levels of capital flows and was significantly wider than others at the same level of network intensity. ${ }^{22}$ 
The question now is to what extent interest rates converged within and between clusters. In addition to the cities in the clusters already identified, we draw on interest rate observations from markets that could not be included in the endogenous cluster identification because of insufficient capital flow data. Most of these cities were allocated exogenously to one of the endogenously identified clusters on the grounds of their proximity. The exceptions are cities from the Netherlands and Northern France whose distance from any of the other clusters is significantly larger than the radius of even the largest cluster. We take these cities to form two separate clusters: The Northern and the Southern Netherlands. ${ }^{23}$ Limiting the analysis to the cities identified by endogenous clustering or treating Northern France as a separate group actually strengthens our results. Table 5, columns 3 to 6 , shows long-term trends in the dispersion around the mean within each cluster (upper panel) and between cities in each cluster (lower panel); as before, we rely on city fixed effects estimation (equation 1).

$<$ Table 5 about here $>$

Our earlier analysis indicates that market integration was more dynamic over long than short distances. This is supported by the finding that the evidence for increases in integration is stronger between than within clusters. The 'within cluster'-analysis detects very low dispersion - with differences mostly within 10 percentage points - both at the beginning and end of the period studied (upper panel Table 5, columns 4 and 5). In other words, the results suggest that by and large clusters were well-integrated already in the late Middle Ages and remained so. The only and partial exceptions are Lower Saxony, where there is evidence of significant progress over time, and the Southern Netherlands, for which we find disintegration. It is possible that interest rate divergence there reflected the commercial decline of Antwerp after the mouth of the river Scheldt was closed in 1585 (Israel, 1989, p. 30). 
Interest rate convergence between clusters (lower panel Table 5) mainly concerned regions where differentials were comparatively high at the beginning (column 4). While Westphalia was fairly well integrated from the start, barriers between initially poorly integrated Upper Germany and especially between the Southern and Northern Netherlands and the rest of the Empire apparently eroded over time. To identify when this progress took place, the 'between'-integration panel regression analysis is re-run, using fifty-year dummies instead of a time trend. The results suggest that the timing of each cluster's integration with the rest of the Empire varied. Thus, Upper Germany saw much progress before the midfifteenth century. The Southern Netherlands started off from a similarly high level of segmentation from the rest of the Empire in the second half of the fourteenth century but advanced rapidly between the sixteenth and the first half of the seventeenth centuries. Finally, the main period of convergence of the Northern Netherlands was slightly later, coinciding with the 'Dutch Golden Age. ${ }^{24}$

\section{A Hypothesis: Benefits of Empire}

The descriptive analysis of annuity yields suggests a strong contrast between a well integrated Empire and comparatively poorly integrated Italy. While the causal analysis of these differences is a task for future research, we hypothesise that the Empire's constitutional structure and politics helped inter-urban exchange and yield convergence.

Geography clearly did not favour the regions north of the Alps, large parts of which, unlike Italy, had no direct access to the sea. Further, it is uncontroversial that the Italians pioneered the use of sophisticated financial instruments such the bill of exchange and giro transfers (see, for example, Day 1987, passim; Felloni 2008, passim; Denzel 2008, pp. 5153). Thus, neither geography nor the development of financial techniques can account for the edge in capital market integration that the late medieval and early modern Empire enjoyed. 
Of course, in the late Middle Ages many Italian communes were much wealthier than the towns north of the Alps and able to draw on more substantial domestic supplies of capital. This probably made them less dependent on loans from outsiders (see Spruyt 1994, pp. 14546). At the same time, Italian bankers specialised in lending to European princes such as Edward III, rather than to neighbouring towns. Still yield dispersion in Italy remained comparatively high even after the sixteenth century, when the Italian bankers had lost their international prominence, Italian income was no longer particularly high, and urban debts were rapidly expanding (Braudel 1982, pp.169-74; Malanima 2011, p. 188; Chilosi 2014, pp. 897-98).

Financial markets in premodern Europe were often tied to commodity trade. With high information cost and slow communications, trade links and commercial correspondence were highly relevant sources of information on arbitrage opportunities. Also, bonds could sometimes be used as collateral for commercial loans; financial flows triggered by arbitrage counterbalanced trade deficits or surplusses, and secondary markets in public securities gave merchants access to capital in another city when a commercial opportunity arose (de Luca 2007, pp. 140-144; Neal 2015, pp. 42-43; Michie 1998, pp. 10-11; Schubert 1988, pp. 9-12). However, in the given context it is unlikely that trade accounts for the differences in the level of capital market integration between Italy and the Holy Roman Empire. There is no evidence suggesting that commercial flows south of the Alps were less intense than in the Empire and could thus account for such differences in integration. ${ }^{25}$ While at first sight this apparent mismatch between trade flows and interest rate gaps may seem counter-intuitive, it is consistent with the insight that in equilibrium interest rate gaps are determined by transaction costs rather than by market thickness and thus efficiency (cf. Federico 2012, pp. 474-475). Thus, geography, financial techniques and trade seem insufficient to explain the differences in 
integration we detect. However, institutions differed markedly between premodern Italy and the Empire, so turning to this factor appears particularly promising.

Italy's fragmented capital markets can be traced back to the times of forced loans in the late Middle Ages. In this period, outsiders needed specific privileges in order to buy annuities, a restriction that aimed at preventing collective reprisals in cases of default (Sieveking 1905, p. 29; Molho 1995, pp. 107-08; Pezzolo 2005, pp. 156-57). In other words, we suggest that because medieval Italian urban governments valued fiscal autonomy (i.e. the right to transform a loan into a tax at will) above access to foreign capital, collective liability (where all merchants from a town were held responsible for the behaviour of each individual) hindered rather than helped the development of inter-city financial links. When securities sold on the primary market replaced forced loans in about 1500, governments relaxed their restrictions. They now often explicitly invited investors from abroad, and interest rate differentials shrank (see Figure 3). ${ }^{26}$ Nevertheless, any gains were short-lived. Foreign investment remained more costly than local. 'Outsiders' were still discriminated against with partial defaults, taxation and liquidations (Pugliese 1924, pp. 339-76; Felloni 1971, pp. 14647, 214-17, 289, 304-06, 315-17; Calabria 1991, pp. 128-29).

The difference to the regions north of the Alps is stark. There, investors acted in an environment shaped by what was probably the most complex political system of premodern Europe: the Holy Roman Empire, a multi-layered organisation whose influence varied over time and between regions. Expecting to find a catch-all institution that can explain the observed patterns on its own would therefore be misguided; rather, several mechanisms seem to have played a role.

Peter Moraw (1989, pp. 155-57, 416-18) has coined the term 'open constitution' to characterise the Empire's pre-sixteenth-century structure, which relied on few formal institutions and allowed many towns to develop their own legal systems. If they were not 
granted the law of an already existing town when they were founded, they often modelled their law codes on that of a neighbouring town. The laws of Aachen, Frankfurt, Nuremberg, Vienna, Brunswick, Magdeburg and Lübeck played important roles in this context. In effect, ‘urban law families' emerged (Kroeschell 2003, p. 25), making legal fragmentation far less pronounced than a look at the political map of the late medieval Empire would suggest. Moreover, unlike in Italy the widespread use of collective liability in the late Middle Ages may here actually have helped co-ordinating inter-urban exchange (Fryde and Fryde 1963, pp. 528-29, 533; Zuijderduijn 2009, ch. 3; Boerner and Ritschl 2002, passim). Indeed, Edmund Fryde and Matthew Fryde (1963, pp. 528, 533) argue that as a result of collective liability foreign investment in the Empire was less risky than domestic investment.

Legal congruence and collective liability functioned within a political system characterised by the co-operation of groups of towns. Urban leagues formed, for example, to negotiate commercial treaties with rulers - this applies to the Hansa (Dollinger 1981, pp. 4143) - or to provide military security - such as the Rhenish League of 1257 (Distler 2006, pp. 180-81). Regardless of how co-operation was motivated, it reduced transaction costs - for example, by facilitating information flows - and so helped inter-urban investment. This reasoning agrees well with our finding that the markets characterised by the strongest intercity capital flows, the Lower-Saxon cluster centred on Lübeck and Lüneburg, formed the core of the Hanseatic League.

From the late fifteenth century onwards, when the Empire was fundamentally reformed (Angermeier 1984), urban leagues began to decline and urban law was assimilated into the legal codes that princes published within the framework of the Empire's legislation (Wüst 2003, pp. 17-19). The Empire itself, that is, its Diet and the Supreme Courts, consistently favoured the rights of creditors. The threat that a Free Imperial city which failed to service its debts might be put under forced administration by an Imperial Debit Commission provided 
incentives for punctual repayment (Kleinehagenbrock 2011, p. 71, Westphal 2002, pp. 26567). This implied a fall in monitoring costs. To the extent that such costs typically increased with distance (Stasavage 2011, passim), their reduction is expected to affect long-distance investment, in particular.

How this played out in the case of territorial towns (not represented at the Imperial Diet but at least nominally under the rule of a prince) is a question that research has so far failed to address. However, any prince would have jumped at the chance to restrict urban autonomy, and when a town's creditors accused it of failing to service its debts this gave him a perfect excuse to bring such towns under his authority (cf. Kern, 2000). In consequence, as long as territorial towns were able to sell their own securities, they faced strong incentives to pay their creditors reliably as otherwise they would risk losing their autonomy.

Within the Empire, competition between authorities appears to have encouraged governments to improve the quality of their institutions. The Imperial constitution channeled political rivalries into forms that ultimately proved economically beneficial: Rather than degenerating into the Macchiavellian type of violence that characterised relations between the Italian states, rivalries between members of the Empire generally played out as peaceful competition for scarce mobile resources such as capital (Volckart, 1999, passim; 2002, pp. 184-86; see also Mokyr, 2017, pp. 170-72). ${ }^{27}$ For example, from the early fifteenth century onwards urban officials and private agents acted as intermediaries, attracting capital from abroad. ${ }^{28}$ Sometimes cities even arranged the pay-out to be delivered at the place of residence of the buyer, apparently at no extra cost. ${ }^{29}$ Moreover, some contracts stipulated that the annual interest payment or, in cases of redemption, the repayment of the principal should occur in a place convenient for both parties. Occasionally fairs such as those in Frankfurt and Leipzig, and specialised markets like Hildesheim, were used for this purpose. ${ }^{30}$ By contrast, early modern Genoese capitalists investing in other Italian cities had to pay a fee to a private 
agent to have the payments delivered to them at financial fairs or at the local public bank (Felloni 1971, pp. 96-97).

While the Thirty Years War marked a temporay break down of the Imperial constitution and was a cataclysm of unparalleled proportions, Sheilagh Ogilvie's (1992, pp. 437-39) negative assessment of the effects of the 'seventeenth-century crisis' needs to be qualified. Promoting peace between its members remained the Empire's core function, and its institutions, including those relevant for capital markets, proved resilient after the Peace of Westphalia (Press 1991, pp. 379-84). Thus, Imperial Debit Commissions that administered states in danger of default remained in place into the early years of the nineteenth century (Westphal 2002, pp. 370-71). In sum, within the Empire inter-urban investment was far better protected than in Italy, where rivalries between polities increased transactions costs.

Factors other than creditor rights protection and competition between political authorities likely played some role, too. After all, it was not just regions such as Upper Germany, where Imperial institutional reach was deep, that integrated rapidly with the rest of the Empire from initially low levels, but also the Netherlands, where Imperial institutions had never been strong and weakened further from the sixteenth century (Press 1986). The Habsburg Netherlands attained a special constitutional status in 1548 but remained part of the Empire. Maximilian I (1459-1519) established the first regular postal route between the Netherlands and Upper Germany in the 1490s (Behringer 2011, pp. 348-49), and Charles V (1500-58) chose Antwerp to remit American silver across Germany and to raise loans from the Fuggers of Augsburg (Braudel 1982, pp. 150-51). The links so established coincided with the use of newly negotiable bills of exchange (Munro 2003, pp. 553-55) and aided inter-urban communications with the rest of the Empire. While not directly concerning annuity markets, such connections made for easier information flows and, all else being equal, reduced risk and so helped long-distance investment in long-term urban debts. Hence, in this instance, 
Imperial politics - if not Imperial institutions - likely fostered the development of interregional capital flows.

\section{Conclusion}

Our analysis draws on a new dataset that extends the quantitative evidence available up to now. The findings demonstrate that Central European annuity markets were better integrated in terms of interest rate dispersion than their Italian counterparts. Comparing both regions reveals that in the early modern period integration advanced in the long run only in the Empire. While there was progress in Italy in the sixteenth century, the gains made there were short-lived. Within the Empire, cities in close proximity were well integrated from the start; the advances in integration that took place from the sixteenth century onwards concerned primarily markets more than 200 kilometres apart. The size and depth of the market reached particularly high levels around Lübeck and Hamburg, and it was in the main initially poorly integrated clusters of cities in the Netherlands and Upper Germany that improved their integration with the rest of the Empire.

Italian merchants and financiers had an undisputed edge in financial techniques. Yet Italian annuity markets were far less well integrated with each other than those in the Empire. The hypothesis emerging from the analysis of the data is that this difference was primarily due to institutions. Foreign investors north of the Alps were throughout far better protected than in Italy as urban authorities in the Empire improved the quality of their institutions in order to attract foreign capital. The Imperial constitution, which excluded the fiefs in Italy, appears as a credible deep cause of this contrast. Our findings challenge the argument that transaction costs are necessarily lower within territorial states than between cities in different polities (cf. Epstein 2000, p. 159). Given a constitutional framework that fostered cooperation between polities and induced them to compete by improving their protection of 
property rights, political fragmentation and constitutional decentralisation do not per se and by necessity have adverse effects on the development and integration of capital markets (cf. Epstein 2000, p. 167; Volckart 2002, pp. 213, 217; Stasavage 2011, pp.162-64.). Testing these hypotheses formally remains the task for future research.

\section{Online Appendix A: Data Sources}

For each market, the entry first gives a description of the data and period coverage, followed by printed and/or archival sources.

Aachen: 20 interest rates on life annuities yielding six yearly means (1385-1439)

Kraus, T.R. (ed.) 2004. Die Aachener Stadtrechnungen des 15. Jahrhunderts. Düsseldorf, pp. $42,57,93,168$.

Laurent (ed.) 1866. Aachener Stadtrechnungen aus dem XIV. Jahrhundert nach den Stadtarchiv-Urkunden mit Einleitung, Registern und Glossar. Aachen: P. Kaatzer, pp. 295,369 .

Amiens: two interest rates on heritable annuities yielding two yearly means (1316 and 1494) and 1 interest rate on a life annuity yielding 1 yearly mean (1388)

Espinas, G. 1902. Les finances de la commune de Douai, des origines au XVe siècle. Paris: Picard, pp. 321, 328.

Maugis, M. E. 1899. Essai sur le Regime Financier de la Ville d'Amiens du a la fin du XVI siècle (1356-1588). In Memoires de la Societe des Antiquaires de Picardie, Quatrieme Serie, Tome III, pp. 133-656, here pp. 563, 566. 
Amsterdam: 847 interest rates on heritable annuities yielding 36 yearly means (1515-1795) and 1095 interest rates on life annuities yielding 36 yearly means (1543-1651)

Daston, L. 1988. Classical Probability in the Enlightenment. Princeton: Princeton University Press, p. 121.

Fritschy, W. 2003a. Three centuries of urban and provincial public debt: Amsterdam and Holland. In Boone, M., Davids, K., and Janssens, P. (eds.) Urban Public Debts: Urban Government and the Market for Annuities in Western Europe (14th-18th Centuries). Turnhout: Brepols Publishers, pp. 75-92, here pp. 79, 83.

Tracy, J. D. 1985. A Financial Revolution in the Habsburg Netherlands: Renten and Renteniers in the County of Holland, 1515-1565. Berkeley, Los Angeles and London: University of California Press, pp. 45, 60, 133.

Van der Burg, M. and Hart, M. 2003. Renteniers and the recovery of Amsterdam's credit (1578-1605). In Boone, M., Davids, K., and Janssens, P. (eds.) Urban Public Debts: Urban Government and the Market for Annuities in Western Europe (14th-18th Centuries). Turnhout: Brepols Publishers, pp. 197-218, here pp. 200, 204.

\section{Stadsarchief Amsterdam [Amsterdam City Archives]:}

No. 5014: Stadsrekeningen. Vol. 12, fol. 38v; Vol. 19, fol. 32r; Vol. 21, fol. 38v; Vol. 22, fol. 40v; Vol. 27, fol. 42v-43r; Vol. 33, fol. 54v; Vol. 34, fol. 52r; Vol. 36, fol. 55v56r; Vol. 39, fol. 88r-89v; Vol. 40, fol. 55v-57v; Vol. 41, fol. 55v-57v; Vol. 42, fol. 62v63v; Vol. 43, fol. 64v-66v; Vol. 44, fol. 61r-62v; Vol. 46, fol. 89r-90v; Vol. 47, fol. 60r61v; Vol. 48, fol. 59r-61v; Vol. 50, fol. 70r-73r; Vol. 51, fol. 71r-74r; Vol. 52, fol. 72v74r; Vol. 53, fol. 75v-77v; Vol. 54, fol. 68r-69v; Vol. 56, fol. 45v-46r; Vol. 59, fol. 35v; Vol. 61, fol. 35r-36v; Vol. 62, fol. 35v-37r; Vol. 63, fol. 32v-33r; Vol. 65, fol. 29v; Vol. 68; Vol. 69; Vol. 71. 
No. 5025: Vroedschapsresoluties. Vol. 1: 16.1.1536-7.5.1565, fol. 113v, 123v; Vol. 2: 28.5.1565-11.1.1575, fol. 33r, 56v; Vol. 3: 16.1.1575-23.5.1578, fol. 19r-v; Vol. 6: 6.5.1588-1.5.1592, pp. 265, 436-7; Vol. 8: 14.5.1594-7.10.1603, pp. 13-14, 21-23, 25-26, 106-7, 858; Vol. 9: 13.10.1603-5.7.1610, p. 285; Vol. 10: 12.7.1610-28.1.1617, p. 224, 338-40; Vol. 19: 1649 januari 12-1652 augustus 29, fol. 158v.

No. 5044: Reeckeningen van overgeleverde losrenten, lijfrenten op eene lijve ende lijfrentenop twee lijven bij de stadt Amstelredamme verkocht. Vol. 461: Ingediend bij het kantoor der Staten van Holland, 1588 maart 10, fol. 2r, 3r, 12r; Vol. 462: Ingediend bij het kantoor der Staten van Holland, 1588 aug.3, nr. 4, fol. 2r, 3r, 31r; Vol. 463: Ingediend bij het kantoor der Staten van Holland, 1599 feb.17, nr. 7, fol. 1r, 2r, 5v, 9v, $11 \mathrm{r}, 12 \mathrm{r}$.

No. 5044: Register van vercoopingen van Renten. Vol. 464: 1588 5e register gemerkt G, fol. 1r-24v; Vol. 465: 1589 5e register gemerkt F, fol. 1r-10v; Vol. 466: 1590 6e register gemerkt H, fol. 1r-10v; Vol. 467: 1591 6e register gemerkt I, fol. 2r-3r; Vol. 468: -1598, fol. 1r-12v; Vol. 469: 1603 6e register gemerkt M, fol. 1r-3r.

Antwerp: 305 interest rates on heritable annuities yielding 32 yearly means (1472-1775) and 146 interest rates on life annuities yielding 17 yearly means (1639-1778)

Stadsarchief Antwerpen [Antwerpen City Archives]:

[Registratie van erf- en lijrenten Reductiekas, renten op de Aluinen (1640-1642).] R280: 1640-1642, rentmeester Jan van Weerden.

[Registratie van erf- en lijrenten Reductiekas, renten op de Corpus (1748-1750).] R364: 1748-1750, erfrenten.

[Jaarlijke rekeningen van de Reductiekas (1582).] R500: 1e rekening, alle cijnzen en erfrenten. 
[Erf-en lijfrenten van de consumptiekas (1646-1793).] R1513: 1646-1648, erf- en lijfrenten, rentmeester Jan Janssens; R1516: 1655-1657, erf- en lijfrenten, rentmeester Thomas de Potter; R1525: 1670-1672, erfrenten, rentmeester Jan Bruynincx; R1526: 1670-1672, lijfrenten, rentmeester Jan Bruynincx; R1527: 1673-1675, lijfrenten, rentmeester Jan Baptist Huart; R1528: 1676-1678, erfrenten, rentmeester Jan Baptist Poesson; R1533: 1685-1687, erfrenten, rentmeester Norbertus van Mockenborch; R1544: 1703-1705, erfrenten, rentmeester Jan van Miert; R1553: 1718-1720, erfrenten, rentmeester Ignatius Clouwet; R1581: 1775-1777, erf- en lijfrenten, rentmeester Jan Baptist de Wolf; R1582: 1778-1780, erf- en lijfrenten, rentmeester Jacques Jos de Moor.

[Erf- en lijfrenten op de lepel.] R1586: 1678-1681.

Arras: One interest rate on an heritable annuity yielding one yearly mean (1392) and six interest rates on life annuities yielding five yearly means (1241-1300)

Bougard, P. 1988. L'apogee de la ville (1191-1340). In Bougard, P., Hilaire, Y. and Nolibos, A. (eds.) Histoire d'Arras. France: Editions des Beffrois, pp. 53-76, here pp. 63-4.

Munro, J. H. 2003. The Medieval origin of the financial revolution: Usury, rentes, and negotiability. In International History Review, 25:3, 505-62, here p. 525.

Munro, J. H. 2007. The Usury Doctrine and Urban Public Finances in Late-Medieval Flanders (1220-1550): Rentes, Excise Taxes, and Income Transfers from the Poor to the Rich. Paper to be presented to the Washington Area Economic History Seminar at the University of Maryland Baltimore County on Friday, 11 May 2007, p. 10.

Richard, J. 1880. Une conversion de rentes à Arras en 1392. In Bibliothèque de l'école des chartes, tome 41, pp. 518-536, here p. 523. 
Assen: 53 interest rate on a heritable annuities yielding 53 yearly mean (1640-1781) and 63 interest rates on life annuities yielding 63 yearly means (1700-1795)

van der Ent, L. and Fritschy, W. 1998. Gewestelijke financiën ten tijde van de Republiek der Verenigde Nederlanden. Deel 2: Drenthe (1602-1795). Rijks Geschiedskundige Publicatiën uitgegeven door het Instituut voor Nerderlandse Geschiedenis. Kleine Serie, Vol. 91. Den Haag: Instituut voor Nederlandse Geschiedenis. Table III.5.20, p. 210.

Assisi: Five interest rates on heritable annuities yielding five yearly means (1598-1689)

Girelli, A. M. 1992. La Finanza Comunale nello Stato Pontificio del Seicento. Il Caso di Assisi. Padova: Cedam, pp. 65, 69-70, appendix.

Augsburg: 85 interest rates on heritable annuities yielding 24 yearly means (1433-1501) and 6 interest rates on life annuities yielding 4 yearly means (1391-1447)

Espinas, G. 1902. Les finances de la commune de Douai, des origines au XVe siècle. Paris: Picard, p. 328.

Stadtarchiv Augsburg [Augsburg City Archives]:

S169 (1400-1437): Baumeisterbuch 14, 37; S170 (1437-1461): Baumeisterbuch 44-47, 50; S171 (1463-1477): Baumeisterbuch 60, 65-66, 70; S172 (1477-1491): Baumeisterbuch 73, 82; S173 (1491-1501): Baumeisterbuch 87; S174 (1501-1515): Baumeisterbuch 98.

Bar-sur-Aube: One interest rate on a life annuity yielding one yearly mean (1240)

Desportes, P. 1979. Reims et les Rémois au XIIIe et XIVe siècles. Paris: Éditions A. \& J. Picard, p. 129. 
Basel: 1135 interest rates on heritable annuities yielding 159 yearly means (1383-1601) and 685 interest rates on life annuities yielding 165 yearly means (1384-1601)

Harms, B. (ed.) 1909. Der Stadthaushalt Basels im Ausgehenden Mittelalter. Quellen und Studien zur Basler Finanzgeschichte. Abt. 1: Die Jahresrechnungen 1360-1535. Vol. 1. Die Einnahmen. Tübingen: Laupp, passim.

Staatsarchiv Basel-Stadt [Basel State Archives]:

AHA Missiven A 1: Missiven, Konzepte 1409 Oktober 12 - 1413 Dezember 18, pag. 82, 85; AHA Ratsbücher D 1: Abscheidbuch (1526-1542), fol. 135; D 2. Abscheidbuch (1541-1556), fol. 25v; AHA Städtische Urkunden (1180-1798): Nos. 1280, 2502, 2503, 2505, 2947, 2950, 2952, 3000, 3021; AHA Städtische Urkunden (Regesten) (0423-18. Jh.): Urkundenbuch VIII. fol. 95; Umschlag des Öffnungsbuches IV; Umschlag von E 45, no. 1; AHA Finanz H: Jahresrechnungen der Stadt Basel von 1444-1611, Fronfastenrechnungen von 1444-1700. Vols. 1535/36-1601/02.

Bergamo: One interest rate on an heritable annuity yielding one yearly mean (1622)

Pulin, F. 1985. Il Monte di Pietà di Bassano (1492-1797). Vicenza: Edizioni L.I.E., p. 122.

Berlin: 11 interest rates on heritable annuities yielding seven yearly means (1588-1698)

Landesarchiv Berlin [State Archives Berlin]:

Rat zu Berlin. A Rep. 500 Berlinische Kämmereirechnungen: 1693-1694, alte Signatur R IV/3; 1697-1698, alte Signatur R IV/4); Rat zu Berlin. A Rep. 510 Coellnische Kämmereirechnungen: 1589-1590, alte Signatur R I/1; 1596-1597, alte Signatur R I/2; 1598-1599, alte Signatur R I/3. 
Bologna: 92 interest rates on heritable annuities yielding 65 yearly means (1501-1754)

Carboni, M. 1995. Il Debito della Città. Mercato del Credito, Fisco e Società a Bologna fra Cinque e Seicento. Bologna: Il Mulino, p. 86.

Felloni, G. 1971. Gli Investimenti Finanziari Genovesi in Europa tra il Seicento e la Restaurazione. Milano: Dott. A. Giuffrè Editore, pp. 181-182.

Nanni, F. 1968. Erettioni de' Monti della città di Bologna e loro capitali e rendite. In Orlandelli, G. (ed.) Due Relazioni sulla Erezione dei Monti di Pubbliche Prestanze in Bologna (1655-1744). Milan: Antonio Giuffrè, pp. 1-22, here pp. 6-21.

Pradelli, G. 1968. Relazione delle erezioni de Monti o siano luoghi de Monti di Bologna (1744-1762). In Orlandelli, G. (ed.) Due Relazioni sulla Erezione dei Monti di Pubbliche Prestanze in Bologna (1655-1744). Milan: Antonio Giuffrè, pp. 23-117, here pp. 39, 51, $58-9,61,63,65-7,70-2,76,85-87,89,92-3,95-7,99,104-6,108-11,113$.

Vietti, A. 1884. Il Debito Pubblico nelle Provincie che hanno formato il Primo Regno d'Italia Secondo i Documenti del R. Archivio di Stato Lombardo. Milano: Emilio Quadrio Editore, p. 137.

Bonn: 26 interest rates on heritable annuities yielding 20 yearly means (1550-1780)

Stadtarchiv Bonn [Bonn City Archives]:

Ku 80/3 Schuldurkunden, Städtische Schulden. Teil 1: 1550 - 1780; Teil 2: 1550 - 1783; Ku 80/4 Maaß’sches Kapital, 1578-1777 (Städtische Schulden); Ku 80/9 Schuldbrief der Stadt Bonn vom 1. Juni 1761 und darauf sich beziehende Dokumente, 1761 (Städtische Schulden). 
Bremen: 1409 interest rates on heritable annuities yielding 233 yearly means (1357-1802)

Albers, H. 1930. Die Anleihen der Stadt Bremen vom 14. bis zum 18. Jahrhundert. In Veröffentlichungen aus dem Staatsarchiv der freien Hansestadt Bremen, 3, pp. 1-163, here pp. 109-152.

Staatsarchiv Bremen [Bremen State Archives]:

1-Bs Städtische Urkunden: Schuldverschreibungen. Nos. 52a, 54a, 77a, 86a, 103-4, 118a*, 118a.1-b, 126-7a, 131-3a.3.I, 135, 138, 147-8, 153, 155, 158, 166-71, 184-9, 193, 195-6, 198, 201, 203-4, 215, 217-8, 221-2, 224, 241-3, 248-9, 252-4, 258, 268-9, 274-5, 277-9, 281, 283-5, 287, 293-6, 298-300, 302, 304-5, 308-17, 319a, 320, 323-32, 334-41, $343-45,348,350,352,356-7,360,361 \mathrm{a}, 362-3$, 379, 390, 395, 397, 399-400, 410, 419, 422-4, 426-7, 432-3, 437-8, 442, 486a, 567-9, 570-1, 616, 647-8, 680, 762, 772, 786, 791, 805b-805m, 806, 807, 808, 810, 811-811g5, 813-813d, 814-814b, 815-815i, 8151, 816, 816a; 2 Ratsarchiv-R.1.A. Finanzwesen im Allgemeinen: 2-adR.1.A.3.b.1.b. Rhederrechnungen: Verschiedene städtische Ausgaben, Anleihen, Abrechnungen usw. 1462-1496, pp. 9-10; 2-R.1.A.5.b.1.a. Rhederhauptbuch (Butenrenteboek) für auswärtige Gläubiger, 1556-1591, passim; 2-R.1.A.5.b.1.b. Rhederhauptbuch (Binnenrenteboek) für einheimische Gläubiger, 1556-1596, passim; 2-R.1.A.5.b.2. Rhederhauptbuch (Binnenrentebuch) für einheimische Gläubiger (1586-1615), passim; 2-R.1.A.6.b.1.-4. Kopiebücher der städtischen Schuldverschreibungen, 1437-1597. Vols. 1-4, passim.

Brescia: One interest rate on an heritable annuity yielding one yearly mean (1587)

Montanari, D. 2001. Il Credito e la Carità. Volume I: Monti di Pietà delle Città Lombarde in Età Moderna. Milano: Vita e Pensiero, p. 103. 
Bruges: 85 interest rates on heritable annuities yielding 39 yearly means (1464-1645) and 27 interest rates on life annuities yielding 9 yearly means (1294-1632)

Stadsarchief Brugge [Bruges City Archives]:

Beden, Renteniers (betalingen van de renten op de Middelen tot de Beden(1): Register 1, vol. 1, 1626; Register 3, vol. 1, 1697; Kladrekening ontvangsten: 09.10.1294-02.09.1295 (W18); Rekeningen Rentenieren: 02.09.1496-02.09.1497; 02.09.1507-02.09.1508; 02.09.1509-02.09.1510; 02.09.1511-02.09.1512； 02.09.1513-02.09.1514; 02.09.154902.09.1550; 02.09.1551-02.09.1552； 02.09.1603-02.09.1604; 02.09.1699-02.09.1700; Memoriaal 1496-1497; Register '1471' (Hanboek 1596-1577); Rentieren dubbles: R.R. 01.09.1631-02.09.1632; $\quad$ Stadsrekeningen: $\quad$ 02.09.1501-02.09.1502; $\quad$ 02.09.150302.09.1504.

Brunswick: Three interest rates on heritable annuities yielding three yearly means (13961416) and 758 interest rates on life annuities yielding 190 yearly means (1392-1664)

Espinas, G. 1902. Les finances de la commune de Douai, des origines au XVe siècle. Paris: Picard, pp. 320-21, 328.

Stadtarchiv Braunschweig [Brunswick City Archives]:

B I 11 Leibgedingebücher [6 vols.]. Vols. 1-6, passim; B I 12 Weddeschatbücher [12 vols.]. Vol. 1, fol. 1r-2r, 7v, 8r-10v (of 120); Vol. 2, fol. 4r-50r (of 169); Vol. 3, passim; Vol. 4, fol. 9r-53r (of 355); Vol. 5, passim; Vol. 6, fol. 1r-76r; Vol. 7, passim; Vol. 8, fol. 1r-126r (of 398); Vol. 9, fol. 1r-93r (of 500); Vol. 12, fol. 1r-101r (of 461).

Chambery: Two interest rates on heritable annuities yielding two yearly means (1570-1735)

Duboin, C. (ed.) 1818-1868. Raccolta per ordine di materie delle leggi, provvidenze, editti, manifesti ecc. pubblicati (negli Stati di Terraferma) dal principio dell'anno 1681 sino agli 8 Dicembre 1798, sotto il felicissimo dominio della Real Casa di Savoia, per servire 
di continuazione a quella del Senatore Borelli. Torino: Davico e Picco. Tomo 7, Vol. 9, pp. 292-301; Tomo 20, Vol. 22, p. 1335.

Chambly: Three interest rates on on life annuities yielding three yearly means (1260-1262)

Desportes, P. 1979. Reims et les Rémois au XIIIe et XIVe siècles. Paris: Éditions A. \& J. Picard, p. 130.

Colmar: 146 interest rates on heritable annuities yielding 55 yearly means (1408-1741) and 2 interest rates on life annuities yielding 2 yearly means (1441-1508)

Archives municipales de la Ville de Colmar [Colmar City Archives]:

CC 12: 1-12 Registres de cens; CC 13: Registres aux capiteaux engages par Colmar et revenus patrimoniaux; CC 14: Echange de titres avec Zorn von Bulach; CC 15: Capiteaux et cens dus par le gourvernement autrichien a Colmar; CC 16: Obligations, engagements, decomptes; CC 17: Reclamations de la ville a differents bourgeois, quittances, decomptes, lettres de cens, correspondence (1402-1741); CC 18: Listes des cens payes; CC 27: Decomptes, echanges, actes d'achat, heritages, partages (1654-1699); CC 30: Decomptes (1678-1700); CC 31-32: Liquidation de dettes; CC 35: Lettres de cens, releves de fortune, fondations pour de tierces personnes (1393-1693); CC 38: Nombreaux actes.

Cologne: 71 interest rates on heritable annuities yielding 36 yearly means (1370-1476) and 38 interest rates on life annuities yielding 36 yearly means (1350-1476)

Espinas, G. 1902. Les finances de la commune de Douai, des origines au XVe siècle. Paris: Picard, pp. 321, 328.

Knipping, R. (ed.) 1897. Die Kölner Stadtrechnungen des Mittelalters mit einer Darstellung der Finanzverwaltung. Vol. 1: Die Einnahmen und die Entwicklung der Staatsschuld. 
Publikationen der Gesellschaft für Rheinische Geschichtskunde, Vol. 15. Bonn: Behrendt, p. 212.

Cremona: 29 interest rates on heritable annuities yielding 12 yearly means (1550-1628)

Jacopetti, N. I. 1961. Le finanze del comune di Cremona durante la dominazione spagnola. Annali della Biblioteca Governativa e Libreria Civica di Cremona, Vol. XIV. Cremona: Athenaeum cremonense, pp. 44-6.

Montanari, D. 2001. Il Credito e la Carità. Volume I: Monti di Pietà delle Città Lombarde in Età Moderna. Milano: Vita e Pensiero, p. 103.

Cuneo: Three interest rates on heritable annuities yielding three yearly means (1706-1764) and 2 interest rates on life annuities yielding 2 yearly means (1706-1745)

Duboin, C. (ed.) 1818-1868. Raccolta per ordine di materie delle leggi, provvidenze, editti, manifesti ecc. pubblicati (negli Stati di Terraferma) dal principio dell'anno 1681 sino agli 8 Dicembre 1798, sotto il felicissimo dominio della Real Casa di Savoia, per servire di continuazione a quella del Senatore Borelli. Torino: Davico e Picco. Tomo 23, Vol. 25 , pp. 404-407, 531, 557.

Einaudi, L. 1908. La Finanza Sabauda all'Aprirsi del Secolo XVIII e Durante la Guerra di Successione Spagnola. Torino: Società Tipografico-Editrice Nazionale, p. 201.

Delft: One interest rate on a life annuity yielding one yearly mean (1577)

Fritschy, W. 2003b. A financial revolution reconsidered: public finances in Holland during the Dutch revolt, 1568-1648. In Economic History Review, 56:1, 57-89, here p. 64.

Dijon: One interest rate on an heritable annuity yielding one yearly mean (1475)

Humbert, F. 1961. Les Finances Municipales de Dijon du Milieu du XIV Siècle à 1477. Paris: Societe les Belles Lettres, p. 168. 
Dordrecht: Nine interest rates on heritable annuities yielding seven yearly means (14221607) and 7 interest rates on life annuities yielding 6 yearly means (1422-1696)

Tracy, J. D. 1985. A Financial Revolution in the Habsburg Netherlands: Renten and Renteniers in the County of Holland, 1515-1565. Berkeley, Los Angeles and London: University of California Press, p. 45.

Van der Heijden, M. 2003. Renteniers and the public debt of Dordrecht (1555-1572). In Boone, M., Davids, K., and Janssens, P. (eds.) Urban Public Debts: Urban Government and the Market for Annuities in Western Europe (14th-18th Centuries). Turnhout: Brepols Publishers, pp. 183-196, here pp. 186-7, 443.

Regionaal Archief Dordrecht (formerly ,Gemeente Archiev Dordrecht')/DiEP (GAD) [Dordrecht City Archives]:

De grafelijke tijd, 1200-1572. Inv.nr. 433: Rekeningen en verantwoording door de thesauriers: Thesaurier van het groot comptoir, reparaties etc., 1429, fol. 31v, 32r, 33v, $38 \mathrm{v}, 39 \mathrm{r}-\mathrm{v}, 41 \mathrm{r}, 45 \mathrm{v}$.

Douai: Three interest rates on heritable annuities yielding three yearly means (1390-1403) and 6 interest rates on life annuities yielding 6 yearly means (1327-1398)

Espinas, G. 1902. Les finances de la commune de Douai, des origines au XVe siècle. Paris: Picard, pp. 319-20, 325-8, 344.

Erfurt: 358 interest rates on heritable annuities yielding 55 yearly means (1419-1634) and 6 interest rates on life annuities yielding 6 yearly means (1451-1509)

Stadtarchiv Erfurt [Erfurt City Archives]:

0-0/A 41 B Städtische Urkunden: Nos. 1, 3-4, 6-7, 10, 15-16a, 18-19, 73, 80, 83-85; 01/4 Städtische Urkunden: Nos. 3, 7, 9(1), 10-9, 15a , 16a(1), 19a(1), 19b(1), 19c(1), 
20(1), 20a, 20b(1), 20c(1), 21, 21a-b, 21c(1), 21d(1), 22(1), 22a(1), 22c(1), 25(1), 25a(1), 26-9, 30a, 30b(1), 31, 31a-b, 31c(1), 32(1), 32a(1), 32b, 33-5, 36(1), 36a-b, 37(1), 37a-b, 37c(1), 37d, 38a, 38c-d, 39a-c, 41-41e, 41f(1), 42a-b, 42d(1), 43(1), 43a-c, 45(1), 45a(1), 45b(1), 46(1), 46a(1), 47(1), 47a-b, 48, 48a(1), 48b, 49(1), 49a-c, 50-50c, 51, 51a, 52(1), 63-8, 69(1), 70-1, 73, 74(1), 75(1), 78-80, 81(1), 82, 83(1), 84(1), 85(1), 86(1), 87(1), 88, 91-2, 93(1), 95-6, 99, 100, 101(1), 101(4), 102, 103(1), 104(1), 106, 108(1), 109, 110(1), 111(1), 114(1), 115(1), 116(1), 117(1), 118(1), 119(1), 120, 121(1), 123-4, 125(1), 126-8, 129(1), 130, 131(1), 132, 133(1), 134, 142(1), 143, 146-7, 151, 153(2), 156, 220r(2), 268(2), 284, 314(2), 322(1), 323(1), 370-4, 375(1), 377, 378(1), 379, 380-7, 388(1), 389, 390(1), 391(1), 392-3, 394(1), 395, 397(1), 398-9, 400(1), 401, 402(1), 403(1), 404(1), 405-6, 407(1), 408, 409(1), 410-2, 413(1), 462 (2), 541(2), 927(2-3); 1-0/B 8 Finanzwesen: Aktiv- und Passivschulden, Nr. 43, 45; 1-1/21 10 Libri ordinationum: Vol. 1, fol. 1v-2r, 5r-8r, 41v; 1-1/22, 2 Hauptrechnungen: No. 1, fol. 22r23r; No. 12, fol. 26v; No. 14, fol. 26v; No. 16, fol. 26v; No. 27, fol. 26v; 1-1/21-12 Obligationen: Vol. 1, pp. 5-10, 70-2, 75-77, 147-9, 279-81, 289-91; Vol. 2, p. 7-8; Vol. 4, fol. 33v-36r.

Ferrara: 16 interest rates on heritable annuities yielding four yearly means (1630-1753)

Felloni, G. 1971. Gli Investimenti Finanziari Genovesi in Europa tra il Seicento e la Restaurazione. Milano: Dott. A. Giuffrè Editore, p. 194-5.

Vietti, A. 1884. Il Debito Pubblico nelle Provincie che hanno formato il Primo Regno d'Italia Secondo i Documenti del R. Archivio di Stato Lombardo. Milano: Emilio Quadrio Editore, pp. 143, 149. 
Finale: 14 interest rates on heritable annuities yielding 14 yearly means (1390-1403)

Cattini, M. 1988. Congiuntura economica e pressione fiscale in una comuintà del basso modenese. In Guarducci, A. (ed.) Prodotto Lordo e Finanza Pubblica. Secoli XIII-XIX. Firenze: Le Monnier, pp. 200, 204.

Florence: 134 interest rates on heritable annuities (which include 81 secondary market yields computed with price data) yielding 92 yearly means (1345-1806) and eight interest rates on life annuities yielding eight yearly means (1591-1710)

Barducci, R. 1979. Politica e speculazione finanziaria a Firenze dopo la crisi del primo Trecento (1343-1358). In Archivio Storico Italiano, 137, p. 188.

Barbadoro, B. 1929. Le Finanze della Repubblica Fiorentina. Imposta Diretta e Debito Pubblico fino all'Istituzione del Monte. Firenze: Leo S. Olschki Editore, pp. 666-670, 713.

Conti, E. 1984. L'imposta Diretta a Firenze nel Quattrocento (1427-1494). Roma: Nella Sede dell'Istituto Palazzo Borromini, pp. 12-13, 31, 34.

Cantini, L. (ed.) 1803-1807. Legislazione Toscana Raccolta e Illustrata dal Dottore Lorenzo Cantini Socio di Varie Accademie. Firenze: Stamperia Albizziniana da S. Maria in Campo. Vol. 7 (1803), p. 54; Vol. 13 (1804), p. 255; Vol. 15 (1804), p. 28; Vol. 16 (1805), p. 247; Vol. 17 (1805), p. 215; Vol. 20 (1805), p. 272; Vol. 22 (1806), p. 174; Vol. 23 (1806), p. 21; Vol. 24 (1806), pp. 146, 227, 262; Vol. 29 (1807), p. 352; Vol. 30 (1807), pp. 7, 53, 113, 144.

Cochrane, E. 1973. Florence in the Forgotten Centuries 1527-1800. Chicago: University of Chicago Press, pp. 198-9.

Dal Pane, L. 1965. La Finanza Toscana dagli inizi del Secolo XVIII alla Caduta del Granducato. Milano: Banca Commerciale Italiana, p. 10. 
Felloni, G. 1971. Gli Investimenti Finanziari Genovesi in Europa tra il Seicento e la Restaurazione. Milano: Dott. A. Giuffrè Editore, p. 284.

Menning. C. B. 1993. Charity and State in late Renaissance Italy: On the Monti di Pietà of Florence. Ithaca and London: Cornell University Press, pp. 140, 144, 149, 267, 280-5.

Sapori, A. 1956. Scritti di Storia Economica. Vol. 1. Firenze Sansoni, pp. 238, 347-352.

Stumpo, E. 1984. Finanza e ragion di stato nella prima età moderna. Due modelli diversi: Piemonte e Toscana. In De Maddalena, A. and Kellenbenz, H. (eds.) Finanza e Ragion di Stato in Italia e Germania nella prima Età Moderna. Bologna: Il Mulino, pp. 181-232, here p. 223.

Archivio di Stato di Firenze [Florence State Archive]:

Monte Comune o delle Graticole, Parte I: Pezzo 3, p. 260; Pezzo 4, p. 20; Monte del Sale: Pezzo 1; Pezzo 2, pp. 7, 15, 19, 21, 24; Monte di Pieta': Pezzo 3; Monte di Sussidio Vacabile e Non Vacabile: Pezzo 1; Pezzo 2; Pezzo 3; Pezzo 142, pp. 359-361; Pezzo 143, p. 2-3; Nuovo Monte Comune: Pezzo 383.

Frankfurt am Main: 715 interest rates on heritable annuities yielding 110 yearly means (1546-1766) and 31 interest rates on life annuities yielding 14 yearly means (1561-1599) Institut für Stadtgeschichte Frankfurt am Main [City Archives Frankfurt am Main]:

Rechneiamt Bücher (1341-1889): Nos. 715-6, 830-51.

Freiburg (Breisgau): 106 interest rates on heritable annuities yielding 44 yearly means (1441-1633) and 25 interest rates on life annuities yielding 13 yearly means (1561-1568) Stadtarchiv Freiburg [Freiburg City Archives]:

C1 Akten der städtischen Hauptverwaltung (bis ca. 1860): Gemeindevermögen, vols. 12, 14, 22; E1 Städtische Rechnungen, A I b Städtisches Rentamt, Separat-Rechnung: AI b.1 
Einnahmbücher 1538-9, 1541-5, 1548-50, 1552, 1554, 1558-61, 1568, 1633; AI b.2 Ausgabebücher 1520, 1566, 1569-70, 1572-3, 1575-6, 1597, 1600, 1602, 1604.

Genoa: 551 interest rates on heritable annuities (which include 31 secondary market yields computed with price data) yielding 178 yearly means (1263-1466) and four interest rates on life annuities yielding four yearly means (1630-1683)

Cuneo, C. 1842. Memorie Sopra l'Antico Debito Pubblico, Mutui, Compere e Banca di S. Giorgio in Genova. Genoa: Stamperia dei Sordomuti, pp. 309-311.

Day, J. 1963. Les Douanes de Gênes 1376-1377. Tome I. Paris: S.E.V.P.E.N., pp. xxv-xxvi.

Giacchero, G. 1979. Il Seicento e le Compere di S. Giorgio. Genova: Sagep Editrice, pp. 288, 291, 336, 347, 359, 539.

Heers, J. 1961. Gênes au XV Siècle. Paris: S.E.V.P.E.N., p. 130.

Sieveking, H. 1905. Studio sulle finanze genovesi nel Medioevo e in particolare sulla Casa di S. Giorgio. Trans. by O. Soardi. In Atti della Società Ligure di Storia Patria, $\quad$ Vol. XXXV:1, pp. 63-70.

Archivio di Stato di Genova [State Archive of Genova]:

Antica Finanza: Pandetta 38, numero 322, 344; Archivio Segreto: 9/1026; Banco di S. Giorgio: Pandetta 17, numero 3081-95, 3111-16, 3135, 3137-8, 3140, 3142, 3144, 3177, 3181-2, 3184; Pandetta 18, numero 610/2464, 2471-7, 2479-80; Camera Finanze: 1093.

Ghent: 288 interest rates on heritable annuities yielding 39 yearly means (1521-1748) and 117 interest rates on life annuities yielding 16 yearly means (1513-1715)

Stadsarchief Gent [Ghent City Archives]:

Leningen an Renten: Vol. 2 (Reeks 404 bis); Losrenten and Lijfrenten (405 bis): Vol. 11 Rentebrieven Projekten stadsrente-brieven; Vol. 12 Rentebrieven; Vol. 15 Listes et 
dclarations au sujet des entes; Rekeningen Tresorier Verkooping Los en Lyfrenten (405 bis): vol.4; Stadsrekeningen (400): Vols. 41, 44, 48-50, 52-3, 60-1, 64-5, 83-4, 86; Stadsrekeningen, Kladboeken van de stedelijke ontvangsten (401 bis): Vol. 1; Stadsrekeningen, Ontvangsten: Vols. 1, 3-4, 8, 10.

Groningen: Four interest rates on heritable annuities yielding four yearly means (1706-1790) and six interest rates on life annuities yielding six yearly means (1666-1669) van der Ent, L. and Enthoven, V. 2001. Gewestelijke financiën ten tijde van de Republiek der Verenigde Nederlanden. Deel 3: Groningen (1594-1795). Rijks Geschiedskundige Publicatiën uitgegeven door het Instituut voor Nerderlandse Geschiedenis. Kleine Serie, Vol. 94. Den Haag: Instituut voor Nederlandse Geschiedenis. Table III.5.42, pp. 285-6.

Göttingen: 114 interest rates on heritable annuities yielding 40 yearly means (1328-1650) and 64 interest rates on life annuities yielding 28 yearly means (1320-1440)

Espinas, G. 1902. Les finances de la commune de Douai, des origines au XVe siècle. Paris: Picard, p. 329.

Stadtarchiv Göttingen [Gottingen City Archives]:

AA Kämmerei Kapitalien: No. 3/ 4518 Kämmerei Kapitalien, 1608-1700 (überwiegend Quittungen), fol. 2r; No. 4/4524 Quittungen und eingelöste Obligationen über für die schwedische Satisfaktion geborgten Geldes, 1648-1655, fol. 6r, 8r, 10r, 13r, 15r, 17r, 19r, 31r; B 7 II Amtsbücher, Kopialbücher: No. 1 Liber parvus copiarum, fol. 5r-36v; No. 2 Liber magnus copiarum (1296-1505), fol. 1r-15v, 17r-22r; No. 3 Novus Liber Papyraceus (1439-1583), fol. 1r-5v. 
Halle (Saale): 644 interest rates on heritable annuities yielding 59 yearly means (1459-1621)

Klinger, J. (ed.) 2011. Das Dresdener Stadtbuch 1477-1495. Edition und Forschung (Inaugural-Dissertation zur Erlangung der Doktorwürde der Philosophie, Kunst- und Gesellschaftswissenschaften der Universität Regensburg). Regensburg, pp. 336-8.

Stadtarchiv Halle [Halle City Archives]:

Urkundenbestand 567.

Landeshauptarchiv Magdeburg [Provincial Archives Magdeburg]:

Cop. Kopiare und andere Amtsbücher (0936-1844), Stadt Halle: no. 395a Kopiar der Obligationen der Stadt Halle (1568-1590), passim; no. 396 Copiarium der Obligationen der Stadt Halle (1591-1620), passim; no. 397 Copiarium der Obligationen der Stadt Halle (1605-1616), passim.

Hamburg: 1962 interest rates on heritable annuities yielding 271 yearly means (1344-1809) and 50 interest rates on life annuities yielding 50 yearly means (1361-1530)

Koppmann, K. (ed.) 1869-1894. Kämmereirechnungen der Stadt Hamburg. 7 vols. Hamburg: H. Grüning et al. Vols. 1-7 (1869-94), passim.

Voigt, J. (ed.) 1912. Die Anleihen der Stadt Hamburg Während der Jahre 1601 bis 1650. In Zeitschrift des Vereins für Hamburgische Geschichte 17, 129-233, here pp. 134-56, 1589, 161-70, 173, 175-88, 190-4, 197, 199, 202-4, 206, 221.

Staatsarchiv Hamburg [Hamburg State Archives]:

111-1 Senat. Cl. VII Lit. L/a no. 2. Vol. 1b. Rotes Stadtbuch, pp. 299-309, 311-339.

311-1 I Kämmerei I. Vol. 2: Urkunden 1496-1866 (Unbefristete Kammerbriefe), passim. 
741-2 Genealogische Sammlungen 53. Kasten 91, Juristische Personen 1331-1370; Kasten 141, Juristische Personen 1426-1454; Kasten 165, Juristische Personen 1455-70; Kasten 187, Juristische Personen 1471-90.

Hanover: 1097 interest rates on heritable annuities yielding 303 yearly means (1315-1723) and 383 interest rates on life annuities yielding 141 yearly means (1350-1606)

Stadtarchiv Hannover [Hanover City Archives]:

Urkunden-Abteilung 1: Allgemeine Urkundensammlung (14.-18. Jh.). Nos. 184, 207, $463,465,481,525,537,542,553,559-60,565,570,587,599,614,618-9,622-3,668-9$, $685,689,701,707,737,741,745,753,835,846-7,935,942,989,1103,1161,1207$, $1268,1272-3,1355,1373,1461,1598,1774,1806,1811,1815,1828$; Urkunden Abteilung 3: Schuldurkunden des Rates (1351-1716). Nos. 1, 9, 12, 14, 18, 25-6, 39, 417, 50-2, 54-7, 59-60, 62, 64, 73, 76-7, 83, 86-90, 96, 93-101, 103-8, 111-3, 115-20, $122-$ $4,128,130,132-4,136-9,141-8,150-64,166,168-73,175-6,178-83,185-6,189,191-6$, 198-206, 208-18, 220-36, 238-41, 248, 251-4, 257-66, 268-78, 280-9, 291-301, 304-38, 340-3, 345-51, 354-64, 366-412, 414-25, 428-42, 444-70, 473-5, 477-9, 482-3, 486-8, $490-1,493-6,498-503,505-29,531-2,536-58,561-646,648-60,662-3,667,669,671-$ 90, 692-3, 695, 698-718, 720-57, 759, 761-87, 789-93, 798-822; Neue Abteilung Bücher 7227-7230: Kämmereibücher. No. 7227, pp. 110-1, 187, 195-6, 232-3, 312-3, 349, 386, 387, 442-3, 486, 524-5, 564, 566, 606, 646, 732-3, 766, 802, 836, 876, 912, 956, 998, 1116; no. 7228, pp. 2, 38-9, 78, 165-6, 278, 308, 340-1, 396-7, 430, 434-5, 471, 514, 603, 646, 688, 737, 1233; no. 7229, pp. 2, 27, 381, 383; no. 7230, fol. 30r-v; Neue Abteilung Bücher, 8242 Stadtobligationsbuch 1387-1533, passim; Neue Abteilung Bücher, 8043 Stadtobligationsbuch I, passim; Neue Abteilung Bücher, 8044 Stadtobligationsbuch II, passim; Neue Abteilung Bücher, 8060 Schuldbuch betreffend die angeliehenen Kapitalien, fol. 4r-v, 5v, 6r, 8r-v. 
Hildesheim: 59 interest rates on heritable annuities yielding 72 yearly means (1333-1600) and 246 interest rates on life annuities yielding 54 yearly means (1328-1564)

Stadtarchiv Hildesheim [Hildesheim City Archives]:

Bestand 1 Nr. 1275: Schuldverschreibungen. Nos. 1275a-zzzz; Bestand 50 Nr. 159: Kämmereirechnungen. Vols. 1417, fol. 2r; 1419, fol. 1v; 1420, fol. 1v; 1421, fol. 1v; 1422, fol. 1v; 1425, fol. $1 \mathrm{v} ; 1427$, fol. $1 \mathrm{v} ; 1428$, fol. $1 \mathrm{v} ; 1429$, fol. $1 \mathrm{v} ; 1437$, fol. $1 \mathrm{v}$; 1440, fol. 1v; 1441, fol. 1v; 1442, fol. 130v-131r; 1443, fol. 208v-209r; 1444, fol. 308r; 1445, fol. 2r; 1446, fol. 2r; 1447, fol. 2r; 1448, fol. 2r; 1449, fol. 2r; 1451, fol. 2r; 1452 , fol. 2r; 1453, fol. 2r; 1454, fol. 2r; 1455, fol. 2r; 1456, fol. 2r; 1457, fol. 2r; 1458, fol. 2r; 1459, fol. 2r; 1461, fol. 2r; 1462, fol. 2r; 1464, fol. 2r; 1465, fol. 2r; 1469, fol. 2r; 1490 , fol. 2r; 1491, fol. 2r; 1492, fol. 2r; 1494, fol. 2r; 1496, fol. 2r-v; 1497, fol. 2r-v; 1498, fol. 2r-v; 1499, fol. 2r-v; 1500, fol. 2r-v; 1501, fol. 2r-v; 1502, fol. 2v; 1503, fol. 2v; 1506, fol. 2r; 1508, fol. 2r; 1509, fol. 2r; 1510, fol. 2r-v; 1511, fol. 4r-v; 1512, fol. 81r, 82r-v; 1514, fol. 2r-v; 1519, fol. 90r-92r; 1520, fol. 4r-5r; 1521, fol. 80r-v; 1522, fol. 159r-v; 1523, fol. 2r-3r, 4r; 1524, fol. 80r-81v; 1525, fol. 149r-150r; 1526, fol. 2v-3v; 1527, fol. $67 \mathrm{r}-\mathrm{v} ; 1528$, fol. $134 \mathrm{r}-\mathrm{v}$.

Hoorn: One interest rate on an heritable annuity yielding one yearly mean (1522)

Tracy, J. D. 1985. A Financial Revolution in the Habsburg Netherlands: Renten and Renteniers in the County of Holland, 1515-1565. Berkeley, Los Angeles and London: University of California Press, p. 45.

Huy: 11 interest rates on heritable annuities yielding 10 yearly means (1649-1675)

Morsa, D. 2003. La dette de la ville de Huy au 17e siècle. In Boone, M., Davids, K., and Janssens, P. (eds.) Urban Public Debts: Urban Government and the Market for Annuities 
in Western Europe (14th-18th Centuries). Turnhout: Brepols Publishers, pp. 149-162, here p. 157.

Koblenz: 52 interest rates on heritable annuities yielding 26 yearly means (1610-1797) Stadtarchiv Koblenz [Koblenz Town Archives]:

Bestand 623 Stadt Koblenz: No. 2884 Städtische Schulden (1611-1791), vols/fol. 1, 3, 7, $11,16,18,28,31,38,42,45,49,53,55,62,65,67$; no. 2893 Die Stadtschulden (17941811), vol/fol/pp. 15, 18.

Leeuwarden: 146 interest rates on heritable annuities yielding 49 yearly means (1693-1770) and 54 interest rates on life annuities yielding 28 yearly means (1617-1758)

Trompetter, C. 2007. Gewestelijke financiën ten tijde van de Republiek der Verenigde Nederlanden. Deel 6: Friesland (1587-1795). Rijks Geschiedskundige Publicatiën uitgegeven door het Instituut voor Nerderlandse Geschiedenis. Kleine Serie, Vol. 106. Den Haag: Instituut voor Nederlandse Geschiedenis. Table III.5.44, pp. 185-91.

Leiden: 425 interest rates on heritable annuities yielding 31 yearly means (1439-1530) and 66 interest rates on life annuities yielding 16 yearly means (1361-1530)

Munro, J. H. 2007. The Usury Doctrine and Urban Public Finances in Late-Medieval Flanders (1220-1550): Rentes, Excise Taxes, and Income Transfers from the Poor to the Rich. Paper to be presented to the Washington Area Economic History Seminar at the University of Maryland Baltimore County on Friday, 11 May 2007, p. 34.

Regionaal Archief Leiden [Leiden Provincial Archives]:

SA I (1290-1575): Inv.nrs. 817, 838, 841: Rentebriefe, 1485, 1514, 1527; Inv.nrs. 818835: Register van lijf- en losrenten ten laste van de stad, 1473-1552. Inv.nr. 818, fol. 3v, $8 \mathrm{v}, 17 \mathrm{v}$; inv.nr. 819, 1r, 2v, 4v-8v, 16r, 17v, 18r, 21r-22r, 24r-25r, 28r, 29r-v, 31v, 33v, 
$37 r-v, 42 r-v, 43 r, 44 r-45 r, 46 v, 47 r-v, 48 r-v, 49 v, 54 r, 55 r, 57 v, 58 r, 59 v-60 r, 61 r, 62 v-$ 63v, 68r, 69r, 70v-71r, 73r-v, 76v-77r, 78r, 79v, 80v, 81v, 83r, 83v, 84v, 87r, 88r, 89r90r, 91r, 92r-93v, 94v, 95r, 98r-v, 100r, 101v, 102v, 103v, 104r-105r, 106r, 107v, 109r$\mathrm{v}, 110 \mathrm{r}-\mathrm{v}, 111 \mathrm{v}, 114 \mathrm{v}, 117 \mathrm{v}, 125 \mathrm{r}, 131 \mathrm{r}-\mathrm{v}, 132 \mathrm{r}-\mathrm{v}, 133 \mathrm{v}, 134 \mathrm{r}, 136 \mathrm{r}-\mathrm{v}, 137 \mathrm{r}-\mathrm{v}, 138 \mathrm{r}$, 139r-140v, 141v, 142r-v; inv.nr. 820, fol. 12r, 14r, 18r-v, 20r, 22r, 23r, 24v-25v, 27r-v, 28v; inv.nr. 825, fol. 2r-3r, 4v, 8r, 9r-v, 11v, 14r-v, 15v-16r, 17r, 18r-v, 19v, 20r, 27v, $28 \mathrm{v}, 30 \mathrm{r}-32 \mathrm{r}, 33 \mathrm{r}-\mathrm{v}, 34 \mathrm{r}, 37 \mathrm{r}-\mathrm{v}, 38 \mathrm{r}-\mathrm{v}, 40 \mathrm{r}-42 \mathrm{v}, 47 \mathrm{r}-48 \mathrm{r}, 49 \mathrm{v}-50 \mathrm{r}, 51 \mathrm{r}-52 \mathrm{r}, 53 \mathrm{r}, 54 \mathrm{r}, 55 \mathrm{v}$, 59v, 61r-64r, 65r-v, 66v-67v, 68v, 69r, 70r, 71r-72r, 74v-75r, 76r-v, 77v-78r, 79r-81r, 82r-83r, 84v-85r, 86r-89v, 90r, 92r-93r, 94r-95r, 96r, 97r-v, 99r, 100v-103r, 107v, 112r, 114r, 122r-v, 124r, 125v, 126r, 127v-130r, 131v, 132v, 133r-v; inv.nr. 833a, fol. 43v, 51r-53r, 54v, 55v-56r, 60v-61v, 62v, 63v-64v, 65v-67v, 77r, 78r, 79v, 83r; Inv.nr. 843: Register van de ontvangst uit verkochte lijf- en losrenten, 1528, fol. 5r-6r; Inv.nr. 852: Kwitanties van de koopsom van door de stad verkochte lijfrentebrieven, 1555-1568, nrs. 1-24; Inv.nr. 853: Register van lijfrenten verkocht van 1556 tot $1559.1556-1559$, fol. 1v, 2v-8r; Inv.nr. 856: Stukken betreffende de aankoop van een lijfrente van 24 gulden ten laste van de stad Leiden, voor elk van zijn kinderen gekocht door jonkheer Jacob van der Does, 1565; SA II (1574-1816): Inv.nr. 10161: Los- en lijfrentebrieven ten laste van de stad, uitgegeven in $1600,1604,1672,1674,1681,1684,1780,1789$. Met enkele bijlagen, 1614, 1654, 1796. 1600-1796.

Leipzig: 181 interest rates on heritable annuities yielding 14 yearly means (1475-1625)

\section{Stadtarchiv Leipzig [Leipzig City Archives]:}

JHR 1473-75 (Bd. 2), fol.00175; Titel V 17: Acta des Ratheszu Leipzig Schuld-Wesen betretig de Anno 1625-1642, fol. 168-9, 171-5, 177, 180, 208, 210-1; Title VI 1a: Depostenbuch, fol. 22r; Verzeichnunge der verpferding Jar 1517 (v.2). 
Liège: Three interest rates on heritable annuities yielding three yearly means (1722-1724)

Henry, D. 1975. Les finances de la cité de Liège au XVIIIe siècle. In Finances Publiques d'Ancien Régime. Finances Publiques Contemporaines en Belgique de 1740 à 1860. Processus de Mutation Continuités et Ruptures. Colloque international, Spa, 19-22 December 1972. Bruxelles: Credit Communal de Belgique, pp. 193-218, here pp. 206207.

Lille: 552 interest rates on heritable annuities yielding 128 yearly means (1511-1791) and 666 interest rates on life annuities yielding 86 yearly means (1301-1790)

DuPlessis, R. 1991. Lille and the Dutch Revolt: Urban Stability in an Era of Revolution, 1500- 1582. Cambridge: Cambridge University Press, pp. 76, 260, 264.

Espinas, G. 1902. Les finances de la commune de Douai, des origines au XVe siècle. Paris: Picard, p. 328.

Richebé, A. 1894. Compte de recettes et dépenses de la ville de Lille. 1301-1302. Lille: G. Leleu, p. 24-5.

Sivéry, G. 1970. Histoire économique et sociale. In Trenard, L. (ed.) Histoire de Lille. Tome I: Des Origines à l'avènement de Charles Quint. Lille: Publications de la faculté des lettres et sciences humains de Lille, pp. 111-270, here p. 204.

Archives municipales de Lille [Lille City Archives]:

AG 40; Reg. 2526; Reg. 2527, fol. 2-5, 7-9, 11, 14, 17, 20, 22, 33-4, 37, 40, 42, 52, 56, 63, 66-7, 73, 93, 98, 116, 118-20, 122, 133, 136, 166-7, 169-72, 176-7, 183-5, 190-3, 195, 198, 200-1, 206-8, 210-2, 215-20, 223-4, 232; Reg. 2528, fol. 1-9, 12-3, 15, 17-8, $20,26-8,34-8,40-2,44,47-9,51-3,55-6,58-9,61-4,66-8,70,72-6,78-80,82,87,90-2$, 94, 96-7, 100-3, 105-7, 109-11, 113, 115, 119-22, 125, 128-34, 137-40, 142, 144-5, $147-$ $8,150,153-4,157,159,161-4,167-9,172-3,175,177,179-80,182-3,185-6,189,191$, 
194-201, 203-4, 227-9, 231, 233-9, 241-2, 244-5, 247-8, 250-2, 255, 257-8, 262, 273, 275-6; Reg. 2529; Reg. 2530; Reg. 2531; Reg. 2898, fol. 14, 17, 29, 41; Reg. 2899; Reg. 2900, fol. 9-10; Reg. 2946; Reg. 16012, fol. 11-12; Reg. 16014, fol. 10-1; Reg. 16030, fol. 9; Reg. 16031, fol. 9; Reg. 16032, fol. 9; Reg. 16033, fol. 9; Reg. 16035, fol. 8; Reg. 16036, fol. 9; Reg. 16037, fol. 7-8; Reg. 16039, fol. 7; Reg. 16040, fol. 7; Reg. 16042, fol. 7; Reg. 16043, fol. 6-7; Reg. 16045, fol. 8; Reg. 16046, fol. 8; Reg. 16048, fol. 9; Reg. 16050, fol. 8; Reg. 16051, fol. 8; Reg. 16052, fol. 9; Reg. 16053, fol. 9; Reg. 16054, fol. 8; Reg. 16055, fol. 8-9; Reg. 16063, fol. 6; Reg. 16067, fol. 7; Reg. 16069, fol. 7; Reg. 16070, fol. 7-8; Reg. 16071, fol. 7; Reg. 16072, fol. 7; Reg. 16073, fol. 6; Reg. 16074, fol. 6; Reg. 16075, fol. 6; Reg. 16076, fol. 7-8; Reg. 16077, fol. 7; Reg. 16078, fol. 7; Reg. 16080, fol. 6; Reg. 16084, fol. 7; Reg. 16085, fol. 6; Reg. 16088, fol. 5-6; Reg. 16092, fol. 6; Reg. 16093, fol. 6-7; Reg. 16096, fol. 5; Reg. 16098, fol. 5; Reg. 16265, fol. 47; Reg. 16723; Reg. 16729; Reg. 16730; Reg. 16731; Reg. 16732; Reg. 16733; Reg. 16734; Reg. 16736; Reg. 16737; Reg. 16771; Reg. 16783; Reg. 16785, fol. 177, 181-2; Reg. 16786.

Lübeck: 464 interest rates on heritable annuities yielding 93 yearly means (1439-1530) and six interest rates on life annuities yielding five yearly means (1286-1526)

Archiv der Hansestadt Lübeck [Lübeck City Archives]:

03.04-01.44.1. Kämmerei, Rentebücher: Nos. 1916 (1516-1530), 1917 (1545-1582), 1918 (1582-1612), 1919 (1612-1661); 03.04-02.9.3. Stadt-Cassa: No. 1402, Jährliche Rentebücher Nr. 2 (1667-1669); no. 1403, Jährliche Rentebücher Nr. 3 (1670-1671); no. 1404, Jährliche Rentebücher Nr. 4 (1672-1673); no. 1405, Jährliche Rentebücher Nr. 5 (1674-1675); 1406, Jährliche Rentebücher Nr. 6 (1676-1677); no. 1413, Jährliche Rentebücher Nr. 13 (1689-1690); no. 1423, Jährliche Rentebücher Nr. 23 (1708-1709); no. 1433, Jährliche Rentebücher Nr. 33 (1719); no. 1437, Jährliche Rentebücher Nr. 37 
(1723); no. 1447, Jährliche Rentebücher Nr. 47 (1733); no. 1457, Jährliche Rentebücher Nr. 57 (1743); no. 1464, Jährliche Rentebücher Nr. 64 (1750); 08.01-5.1.02. Wissenschaftliche Handschriften, Brandt, Ahasver von: No. 1054, Auszüge der Renteneinträge aus dem Oberstadtbuch 1320-1350 von A. v. Brandt; 08.01-5.2.1. Bearbeitung der Urkunden und Testamente im AHL: No. 1046, Materialien u. Vorarbeiten zum Lübecker Urkundenbuch, besonders für Band VI-XI. Kämmereibücher: Mappe 2-4.

Lüneburg: 2014 interest rates on heritable annuities yielding 243 yearly means (1363-1718) and 66 interest rates on life annuities yielding 14 yearly means (1386-1563)

\section{Stadtarchiv Lüneburg [Lüneburg City Archives]:}

UA (Urkunden-Abteilung). C: 1363 August 14; c: 1368 Oktober 18 I; b: 1370 November 6; c: 1372 Januar 13; c: 1372 April 5; c: 1374 April 25; a: 1375 Juli 22; b: 1376 Mai 15; c: 1377 Februar 14 II; c: 1386 September 16; c: 1389 August 9; c: 1421 November 10; c: 1422 September 28 II; b: 1423 Juli 28; c:1426 September 28; b: 1428 Marz 14; c: 1428 April 27; c: 1428 Mai 21; c: 1428 Juni 11; b: 1428 Oktober 30; ; c: 1429 April 3 II; c: 1429 April 10; b: 1429 April 26 I; b: 1430 September 20 I; c: 1430 September 20 II; b: 1431 April 9 I; c: 1431 April 9 II; b: 1431 Juni 28; c: 1431 September 29; c: 1432 April 9; c: 1433 Juli 13; c: 1434 April 4; c: 1434 Juni 23; c: 1437 Dezember 27 II; b: 1431 Dezember 31; b: 1439 April 4 II; c: 1439 April 9; c: 1439 September 28 I; c: 1439 Oktober 4; c: 1439 Oktober 18; c: 1439 Oktober 27; c: 1440 Juni 23 I; c: 1440 September 28; c: 1440 Oktober 18; c: 1441 April 10 I; c: 1441 April 10 II; c: 1441 April 10 III; c: 1441 April 18 I; c: 1441 April 18 II; c: 1441 Juni 3; c: 1443 Juni 23 II; AB 51: Darlehensregister (1368-1416), passim; AB 55: Kopie von Rentenbriefen (1441-1492), passim; AB 60: Abschriften von Schuldverschreibungen des Rates zu Lüneburg, passim; AB 65: Schuldurkunden des Rates mit alphabetischem Inhaltsverzeichnis (1492-1516), 
passim; AB 68: Registrum der Renthe bynnen unde buthen Lüneburg, de me hyr bynnen betaleth (15. \& 1. Drittel 16. Jh.), passim; AB 69: Einnahmen und Ausgaben sowie Rentenbriefe (1534/1565, 1566, 1586), passim; AB 71: Kopien von Verschreibungen des Rates aus der Zeit von 1566 bis 1616, passim; AB 80: Schuldbuch mit Ratsrenteverschreibungen, passim.

Lyon: Eight interest rates on heritable annuities yielding five yearly means (1536-1724)

Doucet, R. 1937. Finances municipales et crédit public à Lyon au XVIe siècle. Paris: M. Rivière, pp. 11-12, 49-50, 66.

Gascon, R. 1971. Grand Commerce et Vie Urbaine au XVIe Siècle. Lyon et ses Marchands. Paris: SEVPEN, p. 256.

Paillard, P. 2012. La Cour des Monnaies de Lyon. Lyon: Jacques Andre Editeur, p. 27.

Mainz: Nine interest rates on heritable annuities yielding 2 yearly means (1410-1436) and 25 interest rates on life annuities yielding 2 yearly means (1410-1436)

Bayerisches Staatsarchiv Würzburg [Würzburg State Archives]: Rechnung 50576, 12-16.

Mantua: 38 interest rates on heritable annuities yielding 38 yearly means (1655-1787)

Montanari, D. 2001. Il Credito e la Carità. Volume I: Monti di Pietà delle Città Lombarde in Età Moderna. Milano: Vita e Pensiero, pp. 50-1, 68-9, 78-9, 243.

Meaux: One interest rate on a life annuity yielding one yearly mean (1274)

Desportes, P. 1979. Reims et les Rémois au XIIIe et XIVe siècles. Paris: Éditions A. \& J. Picard, p. 130. 
Memmingen: 674 interest rates on heritable annuities yielding 97 yearly means (1694-1805)

Stadtarchiv Memmingen [Memmingen City Archives]:

Bestand A Reichsstadt. Vol. 429F: Journal Lit. F (Zinseinnahmen, chronologisch), 17701787; Bestand A Reichsstadt. Vol. 430C: Zinsbuch Lit. C (mit Zinseinträgen bis ca. 1747), 1694 - 1720; Bestand A Reichsstadt. Vol. 430D: Zinsbuch Lit. D (mit Zinseinträgen bis ca. 1780), 1720-1747; Bestand A Reichsstadt. Vol. 430E: Zinsbuch Lit. E (mit Zinseinträgen bis ca. 1800), 1747-1765; Bestand A Reichsstadt. Vol. 430F: Zinsbuch Lit. F (mit Zinseinträgen bis 1808), 1766-1791.

Milan: 143 interest rates on heritable annuities yielding 134 yearly means (1535-1796)

Caizzi, B. 1968. Industria, Commercio e Banca nella Lombardia del XVIII secolo. Milano: Banca Commerciale Italiana, pp. 153, 169, 191-2.

Cova, A. 1970. Il Banco di S. Ambrogio e l'impiego mobiliare dei redditi nell'economia milanese del Settecento. In Archivio Storico Lombardo, IX, 7-26, here p. 15.

Cova, A. 1972. Il Banco di S. Ambrogio nell'Economia Milanese dei Secoli XVII e XVIII. Milano: Giuffrè Editore, p. 331.

De Luca, G. 2003. Debito pubblico, sistema fiscale ed economia reale nella Lombardia spagnola: l'aleinazione delle entrate. Prime direzioni di ricreca. In Rizzo, M., Ruiz Ibanez, J. J. and Sabatini, G. (eds.) Le forze del principe. Recursos, instrumentos lymítes en la práctica del poder soberano en los territorios de la Monarquía Hispánica. Murcia: Universidad de Murcia. Vol. I, pp. 179-210, here pp. 185-6.

De Luca, G. 2007. Debito pubblico, mercato finananziario ed economia reale nel Ducato di Milano e nella Repubblica di Venezia tra XVI e XVII secolo. In De Luca, G. and Moioli, A. (eds.) Debito pubblico e mercati finanziari in Italia. Secoli XIII-XX. Roma: Franco Angeli, pp. 119-146, here p. 127. 
De Luca, G. 2008. Government debt and financial markets: exploring pro-cycle effects in northern Italy during the sixteenth and seventeenth centuries. In Piola Caselli, F. (ed.) Government Debts and Financial markets in Europe. London: Pickering and Chatto, pp. 45-66, here p. 49, 51.

Felloni, G. 1971. Gli Investimenti Finanziari Genovesi in Europa tra il Seicento e la Restaurazione. Milano: Dott. A. Giuffè Editore, p. 213.

Treccani. 1959. Storia di Milano, Vol. 12, L'Età delle Riforme (1706-1796). Milan: Treccani, p. 153.

Vietti, A. 1884. Il Debito Pubblico nelle Provincie che hanno formato il Primo Regno d'Italia Secondo i Documenti del R. Archivio di Stato Lombardo. Milano: Emilio Quadrio Editore, pp. 87-88, 91-2, 99, 102, 104-6.

Pugliese, S. 1924. Condizione economiche e finanziarie delle Lombardia nella prima metà del secolo XVIII, In Miscellanea di Storia Italiana, Terza Serie, Tomo XXI, 1-495, pp. $360-3,365,367,374$.

Moncalieri: Six interest rates on heritable annuities yielding five yearly means (1611-1624)

Caligaris, G. 1984. Vita e lavoro in una comunità rurale piemontese: Pancalieri nei secc. XVII-XVIII. Bollettino della Società per gli studi storici, archeologici ed artistici della Provincia di Cuneo, 90-91. Cuneo: Società per gli studi storici, archeologici e artistici della provincia di cuneo, pp. 187-8.

Monferrato: Two interest rates on heritable annuities yielding two yearly means (17301731)

Duboin, C. (ed.) 1818-1868. Raccolta per ordine di materie delle leggi, provvidenze, editti, manifesti ecc. pubblicati (negli Stati di Terraferma) dal principio dell'anno 1681 sino agli 8 Dicembre 1798, sotto il felicissimo dominio della Real Casa di Savoia, per servire 
di continuazione a quella del Senatore Borelli. Torino: Davico e Picco. Tomo 7, Vol. 9, p. 303.

Munich: 108 interest rates on heritable annuities yielding 17 yearly means (1382-1558) and 252 interest rates on life annuities yielding 100 yearly means (1372-1553)

Stadtarchiv München [Munich City Archives]:

Bestand Kämmerei, Gemeindevermögen, Passiven (Schulden): Nr. 63/1-3, Ewiggeldund Leibgedingbücher: Verzeichnisse der Gläubiger von Gnadengeldern, Ewiggelder und Leibgedingen: Vol. 1, 1382-1427; vol. 2, 1385-1397; vol. 4, 1428-1558 (Zimelie 28); Bestand Kämmerei, Gemeindevermögen, Passiven (Schulden): Nr. 65, Ewiggeldbriefasbschriften, 1528-1601; Repertorium der Abgelösten Ewiggeldbriefe: Vol. 26; Repertorium der Passiv-Reichnisse, Aktiv-Kapitalien, Pasiv-Kapitalien, Leibgeding: Vol. 28.

Münster: 615 interest rates on heritable annuities yielding 74 yearly means (1447-1685) and 9 interest rates on life annuities yielding 8 yearly means (1447-1646)

Eberhardt, I. 2002. Die Grutamtsrechnungen der Stadt Münster von 1480 und 1533: Edition und Interpretation. Quellen und Forschungen zur Geschichte der Stadt Münster, 19. Münster: Aschendorff, p. 188.

Stadtarchiv Münster [Munster City Archives]:

A VIII 188a Gruetherrenregister (1536 - 1643). Nos. 5, 9, 13, 14; A VIII 277 Kämmereirechnungen (1447-1809). No. 1 (1447-49), fol. 1v, 16v, 17v, 31v, 32r, 43r; A IX Ratsarchiv Urkunden Stadtschulden. Nos. 27a\&b, 28-37, 39, 41, 43-50, 52-54, 56-84, 86-92, 94-101, 103-7, 109-65, 167-71, 173-75, 177-83, 185-211, 213, 216-25, 227-44, $246-51,253-56,259-64,267-8,270,272-3,275-6,278-83,285-6,288-90,292-3,295-$ $98,301-4,306,308-26,328-35,337-40,342,345-6,348-53,355-8,360,362,364-66$, 
$368,370-7,381-3,387-91,393-4,396-8,401-2,404,407-9,411-2,416,418-25,428-34$, 436-41, 444-70, 472-74, 476-502, 504-35, 537-67, 570-642, 644-51, 653-72, 675-81, 683-6, 688, 691-2, 694, 697, 699-714, 727, 728, 729, 730.

Namur: One interest rate on an heritable annuity yielding one yearly mean (1472) and 4 interest rates on life annuities yielding 2 yearly means (1465-1467)

Borgnet, J. and Bormans, S. (eds.) 1876. Cartulaire de la Commune de Namur, recueilli et annoté par J. Borgnet et S. Bormans, Vol. I. Namur, p. 149.

Brouwers, P. P. (ed.) 1920. Cartulaire de la Commune de Namur, tome quatrieme. Namur: Typographie de ad Wesmael-Charlier, pp. 253-256, 260.

Naples: 200 interest rates on heritable annuities (which include 44 primary market yields computed with price data) yielding 139 yearly means (1498-1796) and seven interest rates on life annuities yielding seven yearly means (1554-1611)

Banco di Napoli (ed.) 1972. L'Archivio Storico del Banco di Napoli. Una Fonte Preziosa per la Storia Economica Sociale e Artistica del Mezzogiorno d'Italia. Napoli: Banco di Napoli, pp. 69, 74, 95.

Bianchini, L. 1971. Storia delle Finanze del Regno delle due Sicilie. Napoli: Edizioni Scientifiche Napoletane, p. 276.

Bulgarelli Lukacs, A. 1993. L'Imposta Diretta nel Regno di Napoli in Età Moderna. Roma: Franco Angeli, pp. 49-50, 53.

Bulgarelli Lukacs, A. 2007. Il debito pubblico in ambito municipale. Stato, comunità e creditori nel Regno di Napoli tra seicento e settecento. In De Luca, G. and Moioli, A. (eds.) Debito Pubblico e Mercati Finanziari in Italia. Secoli XIII-XX. Roma: Franco Angeli, pp. 327-64, here p. 340. 
Calabria, A. 1991. The cost of empire: The finances of the kingdom of Naples in the time of Spanish rule. Cambridge: Cambridge University Press, pp. 143-5.

Caracciolo, F. 1988. Il credito allo stato e la rendita pubblica nel Regno di napoli in età spagnola: costante esigenza del governo di abbassare il saggio di interesse remunerando di meno il credito erogato dai privati. In Società Italiana degli Storici dell'Economia (ed.), Credito e Sviluppo in Italia dal Medio Evo all'Età Contemporanea. Verona: Monduzzi, pp. 217-25, here pp. 217-8, 220, 223.

Capasso, B. (ed.) 1876. Catalogo Ragionato dei Libri Registri e Scritture Esistenti nella Sezione Antica o Prima Serie dell'Archivio Municipale di Napoli (1387-1806). Napoli: Stabilimento Tipografico del Cav. Francesco Giannini, pp. 69, 73, 75-8, 83, 85-6, 88-9, 91.

Coniglio, G. 1955. Il Viceregno di Napoli nel sec. XVII. Notizie sulla Vita Commerciale e Finianziaria secondo Nuove Ricerche negli Archivi Italiani e Spagnoli. Roma: Edizioni di Storia e Letteratura, pp. 65, 151, 199.

Demarco, D. 2000. Il Banco di Napoli. L'Archivio Storico: La Grammatica delle Scritture. Napoli: Edizioni Scientifiche Italiane, pp. 103, 110, 112, 114-6, 125-6.

De Rosa, L. 1958. Studi sugli arrendamenti del Regno di Napoli: aspetti della distribuzione della ricchezza mobiliare nel Mezzogiorno continentale, 1649-1806. Napoli: Arte Tipografica, pp. 11, 17, 24, 30-1, 34, 43, 44-7, 57-61, 64-6, 68-9, 76, 181-2, 188, 213-4, $235-7,240,246$.

Felloni, G. 1971. Gli Investimenti Finanziari Genovesi in Europa tra il Seicento e la Restaurazione. Milano: Dott. A. Giuffrè Editore, p. 303.

Malanima, P. 1977. I Riccardi di Firenze. Una Famiglia e un Patrimonio nella Toscana dei Medici. Firenze: Olschki, p. 101. 
Placanica, A. 1982. Moneta, Prestiti e Usure nel Mezzogiorno Moderno. Napoli: Società Editrice Napoletana, p. 231.

Romano, R. 1976. Napoli: dal Viceregno al Regno. Torino: Einaudi, p. 38.

Sabatini G. 2008. From subordination to autonomy: public debt policies and the formation of a self-ruled financial market in Southern Italy in the long run (1550-1850). In Piola Caselli, F. (ed.) Government Debts and Financial markets in Europe. London: Pickering and Chatto, pp. 97-104, here p. 102.

Tortora, E. 1890. Nuovi Documenti per La Storia del Banco di Napoli. Napoli: Reale Tipografia De Angelis, p. 193.

Zilli, I. 1994. Imposta Diretta e Debito Pubblico nel Regno di Napoli: 1669-1737. Napoli: Edizioni Scientifiche Italiane, p. 94.

Nice: One interest rate on an heritable annuity yielding one yearly mean (1623)

Duboin, C. (ed.) 1818-1868. Raccolta per ordine di materie delle leggi, provvidenze, editti, manifesti ecc. pubblicati (negli Stati di Terraferma) dal principio dell'anno 1681 sino agli 8 Dicembre 1798, sotto il felicissimo dominio della Real Casa di Savoia, per servire di continuazione a quella del Senatore Borelli. Torino: Davico e Picco. Tomo 7, Vol. 9, p. 292.

Nuremberg: 1136 interest rates on heritable annuities yielding 125 yearly means (1388$1551)$ and 11 interest rates on life annuities yielding nine yearly means (1388-1446)

Espinas, G. 1902. Les finances de la commune de Douai, des origines au XVe siècle. Paris: Picard, pp. 321, 329.

Fryde, E. B. and Fryde, M. M. 1963. Public Credit, with Special Reference to North-Western Europe. In Postan, M. Rich, E. E. and Miller, E. (eds.) The Cambridge Economic History 
of Europe: III: Economic Organization in the Middle Ages. Cambridge: Cambridge University Press, pp. 430-553, here p. 548.

Staatsarchiv Nürnberg [Nuremberg State Archives]:

Losungsamt, Ewiggeldbücher: Nos. 69 \& 70, passim.

Osnabrück: 380 interest rates on heritable annuities yielding 135 yearly mean (1437-1767) and 35 interest rates on life annuities yielding 22 yearly means (1403-1499)

Niedersächsisches Landesarchiv - Osnabrück [Provincial Archives of Lower Saxony, Osnabrück]:

Dep. 3 a 1 XI Urkunden, Schulden der Stadt, nos. 3, 5-9a, 10a, 11-20, 22, 24, 36, 39, 435, 48-60, 62-3, 65-70a, 73-84, 86-7a, 88a-96b, 99, 100-107a, 108b, 109-12, 114, 116-8, 125, 138-42, 144-5, 147-51, 153-4, 156-66, 170, 172-7; Dep. 3 a 1 XI Urkunden, Schulden der Neustadt, nos. 3, 15-7; Dep. 3 b II Städtische Rechnungen: Lohnrechnungen, no. 1, fol. 30r, 61r-v, 70v, 139v, 164r-v, 176r, 188r, 202v, 232r, 265r, 290r-v, 306r-v, 326v, 348v, 369v-370v, 391v-392v; no. 2, fol. 6r-v, 25r-v, 48v-49r, 79r, $104 \mathrm{r}, 128 \mathrm{v}, 151 \mathrm{v}, 173 \mathrm{r}, 219 \mathrm{v}, 243 \mathrm{r}, 266 \mathrm{v}, 311 \mathrm{v}, 359 \mathrm{r}, 452 \mathrm{v}, 487 \mathrm{r}-\mathrm{v}, 488 \mathrm{v}, 508 \mathrm{r}$; no. 3 , fol. 7v; no. 5, fol. 148r, 176r, 259r-v; no. 6, fol. 35r, 132v; no. 10, fol. 40v; no. 11, fol. 92v, 270r; Dep. 3 b IV Stadtsachen: No. 372, Renten- und Einkünfteverzeichnis der Neustadt (1579-1621), fol. 17r-20v, 29r-31v; Dep. 3 b IV Stadtsachen: No. 5745, Copiarium der Obligationen der Stadt Osnabrück (1623-1719), fol.1r-6v, 7v-9v, 11v14v, 16r-20v, 22r-v, 24r-25v, 27r-v, 33r-34r, 38r-40r, 41r-43r, 44r-45r, 50r-52v, 57r, 58r59r, 61r-65v, 72r-85v, 92v-94v, 98v-102r, 104r-105r, 106r-110v, 112r-120r, 121r-127r, 128r-v, 130v-131r, 132r, 134r, 135r, 136r, 137r, 138r-139r, 144r-146r, 147r-150r, 151r, 152v-154r, 155r-160r, 161v, 162r-v, 164r-166r, 167r, 170v-173r. 
Palermo: 77 interest rates on heritable annuities yielding 51 yearly mean (1512-1799)

Aymard, M. 1972. Bilancio di una lunga crisi finanziaria. In Rivista Storica Italiana, 84, 9891021, here pp. 997-8, 1002, 1011.

Bianchini, L. 1841. Della Storia Economico-Civile di Sicilia. Volume I. Napoli: Dalla Stamperia Reale, pp. 247, 277, 282-3, 286.

Coniglio, G. 1955. Il Viceregno di Napoli nel sec. XVII. Notizie sulla Vita Commerciale e Finianziaria secondo Nuove Ricerche negli Archivi Italiani e Spagnoli. Roma: Edizioni di Storia e Letteratura, pp. 103-104.

Cusumano, V. 1974. Storia dei Banchi della Sicilia. Edited by R. Giuffrida. Palermo: Flaccovio Editore, pp. 184-5, 318, 338-9, 343, 350, 369, 389, 423.

Favarò, V. 2007. Il debito pubblico nella Sicilia moderna: un bilancio storiografico. In De Luca, G. and Moioli, A. (eds.) Debito Pubblico e Mercati Finanziari in Italia. Secoli XIII-XX. Rome: Franco Angeli, pp. 347-55, here p. 349.

Felloni, G. 1971. Gli Investimenti Finanziari Genovesi in Europa tra il Seicento e la Restaurazione. Milano: Dott. A. Giuffrè Editore, pp. 314-5, 317-8.

Giarizzo, G. and D'Alessandro, V. 1989. La Sicilia dal Vespro all'Unità d'Italia. Turin: UTET, p. 230.

Giuffrida, R. 1976. La politica finanziaria spagnola in Sicilia da Filippo II a Filippo IV (1556-1665). In Rivista Storica Italiana, 88, 311-341, here pp. 321, 323.

Koenigsberger, H. G. 1969. The Practice of Empire. Emende Edition of the Government of Sicily under Philip II of Spain. Ithaca, New York: Cornell University Press, p. 134.

Mack Smith, D. 1968. A History of Sicily. Medieval Sicily 800-1713. London: Chatto \& Windus, p. 174. 
Marrone, G. 1976. L'Economia Siciliana e le Finanze Spagnole nel Seicento. Caltanissetta and Roma: Sciascia, p. 21.

Titone, V. 1974. La Società Siciliana sotto gli Spagnoli e le Origini della Questione Merdionale. Palermo: Flaccovio Editore, p. 104.

Paris: 11 interest rates on heritable annuities yielding 11 yearly mean (1522-1634)

Munro, J. H. 2003. The Medieval origin of the financial revolution: Usury, rentes, and negotiability. In International History Review, 25:3, 505-62, pp. 536-7, 540.

Schnapper, B. 1957. Les Rentes au XVIe Siècle. Histoire d'un instrument de crédit. Paris: S.E.V.P.E.N., pp. 169, 173.

Tracy, J. D. 1985. A Financial Revolution in the Habsburg Netherlands: Renten and Renteniers in the County of Holland, 1515-1565. Berkeley, Los Angeles and London: University of California Press, p. 21.

Pinerolo: Two interest rates on heritable annuities two yearly means (1621-1622)

Abrate, M. 1985. Accumulazione e tassi d'interesse a Torino dalla peste del 1559 a quella del 1630. In Vannini Marx, A. (ed.) Credito, Banche e Investimenti. Secoli XIII-XX. Firenze: Le Monnier, p. 98.

Pisa: 14 interest rates on heritable annuities yielding 14 yearly means (1618-1734)

Bernardini, R. 1974. Il Monte di Credito su Pegno di Pisa. Pisa: Cassa di Risparmio di Pisa, Appendix.

Berti, M. 1988. Note sull'organizzazione e l'amministrazione del Monte di Pietà di Pisa (secoli XVI-XVIII). In Società Italiana degli Storici dell'Economia (ed.), Credito $e$ Sviluppo in Italia dal Medio Evo all'Eta' Contemporanea. Monduzzi: Verona, pp.307323, here pp. 313, 316. 
Reggio Emilia: One interest rate on an heritable annuity yielding one yearly mean (1561)

Fornasari, M. 2001. Il credito come "missione". I monti di pietà tra ducati pagani e legazioni pontificie. In Avallone, P. (ed. ) Il "Povero" Va in Banca: I Monti di Pietà negli Antichi Stati Italiani (Secc. XV-XVIII). Napoli: Edizioni Scientifiche Italiane, pp. 55-76, here p. 67.

Rome: 141 interest rates on heritable annuities yielding 85 yearly means (1526-1793) and 39 interest rates on life annuities yielding 27 yearly means (1550-1786)

Colzi, F. 1999. Il Debito Pubblico del Campidoglio: Finanza Comunale e Circolazione dei Titoli a Roma fra Cinque e Seicento. Napoli, Roma e Milano: Edizioni Scientifiche Italiane, p. 60.

Comune di Roma (ed.) 1920-1958. Regesti di Bandi, Editti, Notificazioni e Provvedimenti Diversi Relativi alla città di Roma ed allo Stato Pontificio. Vols. 1-7. Roma: Comune di Roma. Vol. I, 1920, pp. 14, 24, 48, 51-2, 57, 68, 72, 74, 77, 84, 86-7, 92, 98-9, 104, 110 , 120, 124, 132-4, 144-5, 148; Vol. II, 1925, pp. 14, 25, 31, 34, 40, 43, 51, 66, 72, 92, 100 , $129,142-3,148-9,154,157,172,178,184,189,201-2,213,221-2,225,235,248-9$, 258, 261-2; Vol. III, 1930, pp. 11, 16, 20, 29, 42, 69-70, 84, 150, 217, 220, 223, 232; Vol. IV, 1932, p. 35, 66, 89-90, 120, 169, 189-90; Vol. V, 1934, pp. 53, 67, 70; Vol. VI, 1956, pp. 8, 35, 39, 235, 247, 303; Vol. VII, 1958, pp. 66, 104, 113, 181.

Felloni, G. 1971. Gli Investimenti Finanziari Genovesi in Europa tra il Seicento e la Restaurazione. Milano: Dottor A. Giuffrè Editore, pp. 164-5, 168.

Gross, H. 1990. Roma nel Settecento. Bari: Laterza, p. 154.

La Marca, N. 1988. Il controllo dei mutui agli enti locali nel settecento romano. In Società Italiana degli Storici dell'Economia (ed.) Credito e Sviluppo in Italia dal Medio Evo all'Età Contemporanea. Monduzzi: Verona, pp. 387-98, here p. 389. 
Piola Caselli, F. 1988. La diffusione dei luoghi di monte della camera apostolica alla fine del XVI secolo. In Società Italiana degli Storici dell'Economia (ed.) Credito e Sviluppo in Italia dal Medio Evo all'Età Contemporanea. Monduzzi: Verona, pp. 191-216, here p. 199.

Piola Caselli, F. 1993. Una montagna di debiti. I monti baronali dell'aristocrazia romana nel seicento. In Roma Moderna e Contemporanea, 2, 21-55, here pp. 35, 51.

Piola Caselli, F. 1997. Il Buon Governo: Storia della Finanza Pubblica nell'Europa Preindustriale. Torino: Giapichelli Editore, p. 242.

Piola Caselli, F. 2003. Public debt, state revenue and town consumption in Rome (16th-18th centuries). In Boone, M., Davids, K., and Janssens, P. (eds.) Urban Public Debts: Urban Government and the Market for Annuities in Western Europe (14th-18th Centuries). Turnhout: Brepols Publishers, pp. 93-105, here pp. 93-4.

Strangio, D. 1994. Debito Pubblico e riorganizzazione del mercato finanziario nello stato ecclesiastico del '700. In Roma Moderna e Contemporanea, 1, 179-202, here pp. 175, 177-9, 193-4.

Strangio, D. 1999. Crisi Alimentari e Politica Annonaria a Roma nel Settecento. Roma: Istituto Nazionale di Studi Romani, pp. 175-7, 179-80.

Rotterdam: Four interest rates on heritable annuities yielding two yearly means (1426-1556) and 30 interest rates on life annuities yielding three yearly means (1522-1556)

Tracy, J. D. 1985. A Financial Revolution in the Habsburg Netherlands: Renten and Renteniers in the County of Holland, 1515-1565. Berkeley, Los Angeles and London: University of California Press, p. 45. 
Unger, J.H.W. and Bezemer, W. (eds.) 1899. Bronnen voor de geschiedenis van Rotterdam III: De oudste stadsrekeningen van Rotterdam. Rotterdam: van Hengel, pp. 35, 94-5, $169-71$.

Savona: Two interest rates on heritable annuities yielding two yearly means (1749-1766)

Felloni, G. 1971. Gli Investimenti Finanziari Genovesi in Europa tra il Seicento e la Restaurazione. Milano: Dott. A. Giuffrè Editore, pp. 110.

Felloni, G. 2007. Le attività finanziarie. In Assereto, G. and Doria, M. (eds.) Storia della Liguria. Bari: Laterza, p. 137.

Schaffhausen: 45 interest rates on heritable annuities yielding 15 yearly means (1396-1446) and 43 interest rates on life annuities yielding 15 yearly means (1428-1446)

Stadtarchiv Schaffhausen [Schaffhausen City Archives]:

A II.05.01. Stadtrechnungen: No. 001 Einnahmen/Ausgaben 1396-1397, p. 2; no. 010 Einnahmen/Ausgaben 1410-1411, p. 23; no. 011 Einnahmen/Ausgaben 1411-1412, p. 28; no. 016 Einnahmen/Ausgaben 1416, pp. 4-5, 17, 19; no. 039 Einnahmen 1428-1429, p. 1; no. 041 Ausgaben 1429, p. 1; no. 044 Ausgaben 1429, p. 1; no. 048 Einnahmen 1431-1432, p. 1; no. 049 Ausgaben 1431-1432, pp. 1, 6; no. 051 Einnahmen 1433, p. 1; no. 052 Ausgaben 1432-1433, p. 2; no. 053 Ausgaben 1432, pp. 3, 6, 12; no. 054 Einnahmen 1434, p. 2; no. 055 Ausgaben 1434, p. 2-3; no. 059 Einnahmen 1434-1435, p. 2; no. 060 Einnahmen 1435, p. 2; no. 061 Einnahmen 1435-1436, p. 2; no. 062 Einnahmen 1436, p. 1; no. 063 Einnahmen 1436-1437, p. 3; no. 065 Einnahmen 14381439, p. 2; no. 067 Ausgaben 1438, p. 2; no. 068 Einnahmen 1439-1440, p. 2; no. 069 Ausgaben 1439-1440, p. 4; no. 070 Einnahmen 1440, p. 1; no. 071 Einnahmen 14411442, p. 2; no. 072 Einnahmen 1442, p. 2; no. 073 Einnahmen 1441, p. 3; no. 074 Ausgaben 1441, p. 3; no. 075 Ausgaben 1441-1442, p. 2; no. 076 Einnahmen 1442-1443, 
p. 2; no. 078 Einnahmen 1443-1444, p. 2; no. 079 Ausgaben 1443, p. 3; no. 081 Einnahmen 1444-1445, p. 2; no. 082 Einnahmen 1444, p. 2; no. 085 Einnahmen 1446, pp. 2-3.

Siena: 177 interest rates on heritable annuities yielding 177 yearly means (1624-1800)

Mengozzi, N. 1913. Il Monte dei Paschi e le sue Aziende. Compendio di Notizie Storiche e Statistiche. Siena: Stabilimento Arti Grafiche Lazzeri, p. 280.

Soest: 143 interest rates on heritable annuities yielding 68 yearly means (1429-1716) and 26 interest rates on life annuities yielding 14 yearly means (1499-1524)

Stadtarchiv Soest [Soest Town Archives]:

A 5135: Kopienbuch der der von der Stadt Soest aufgenommenen Kapitalien (14991530), fol. 2r-3v, 4r, 5v, 6r, 7r-13v, 15r-v; A 5137: Kopiar der Leibrentenbriefe der Stadt Soest (1502-1524), fol. 2r-13r, 14r-16v, 17v; A 5141: Designation der Gelder, die im Jahre 1616 zu Behuf der Stadt aufgenommen wurden (1616), 2r; A 5142: Protokoll der von der Stadt Soest herausgegebenen Obligationen (1622-1635), pp. 3, 16-23, 25, 27, 29 32, 34-6, 38, 40, 42; A 5143: Verzeichnis der von der Stadt Soest aufgenommenen Geldsummen (1628), fol. 2v, 4r-v, 6r; A 5144: Abschriftliche Sammlung der von der Stadt Soest herausgegebenen Obligationen (1629-1719), fol. 1r-v, 5r-6r, 10r-11v, 46r-v, 86r-87r, 88r-89r, 116r-117r, 158r-159r, 176r-177r, 186r-187r, 196r-v, 199r-v, 202r-203r, 209r-210r, 214r-v, 216r-v; A 5145: Akten betr. Die Kapitalschulden der Stadt Soest (1636-1719), fol. 12r; A 5154: Aufstellungen über die Obligationen zu Lasten der Stadt Soest (1716), fol. 4v, 6r-8r, 10v-11r; A 5155: Kredittabelle sowie Kredit- und Zinsetat der Stadt Soest (1717), fol. 8v-9r, 10v-11r; A 5161-5383: Kredit- und Schuldenwesen, Specialia, nos. 5175, 5178, 5181, 5191, 5196-5203, 5207-9, 5212-5, 5217, 5219, 5220, 
5222-3, 5225, 5228, 5231-4, 5236-7, 5239-40, 5243, 5245, 5265, 5271, 5288, 5332, $5339,5343$.

St. Omer: Seven interest rates on life annuities yielding seven yearly means (1306-1312)

Derville, A. 1981. Le premiere repli (1350-1550). In Derville, A. (ed.) Histoire de SaintOmer. Histoire des villes du Nord/Pas-de-Calais, 1. Lille: Presses Universitaires de Lille, pp. 73-106, here p. 79.

St. Quentin: Two interest rates on heritable annuities yielding two yearly means (1296-1360) and 4 interest rates on life annuities yielding 4 yearly means (1321-1360)

Desportes, P. 1979. Reims et les Rémois au XIIIe et XIVe siècles. Paris: Éditions A. \& J. Picard, p. 450.

Lemaire, E. (ed.) 1888-1910. Archives Anciennes de la Ville de St. Quentin. 2 vols. Saint Quentin: Au Siege de la Societe Academique, Tome I (1076-1328), p. 130; Tome II (1328-1400), pp. 243-244.

Strasbourg: 893 interest rates on heritable annuities yielding 118 yearly means (1525-1791) and one interest rate on a life annuity yielding 1 yearly mean (1776)

Archives de la Ville et de la Communauté Urbaine de Strasbourg [Strasbourg City Archives]:

Série IV 69-74 Rentes dues par la ville (16ème et 17ème siècle): No. 69, p. 146 ; no. 70, pp. 37, 41, 44, 45, 63, 145; no. 71, pp. 27, 148, 154-9, 177-9; Série VII 1 Emprunts contractés par la ville de Strasbourg pour financer la construction des fortifications ; Remboursements des sommes avancées au magistrat par divers particuliers, pp. 2, 6; Série VII 2A: Remboursements, pp. 1-76; Série VII 7: Rachat de rente, pp. 1, 3, 36-40, 69; Série VII 21, 1: Emprunts faits par la ville (1706/07), p. 1; Série VII 150: Etats des recettes et dépenses de la tour aux Pfennigs (1783-1791); Mémoire de l'avocat de la ville, concernant les revenus et dépenses annuels, état comparatif, état des rentes à la 
charge de la ville. No. 1, fol. 9r, 15r, 21r ; no. 2, fol. 9r, 74r, 80r, 86r, 92r, 104r, 122r, 128r, 134r, 140r, 144r, 151r; no. 3, fol. 3r, 9r, 15r, 27r, 33r, 45r, 56r, 57r, 80r, 86r, 92r, 98r, 104r, 128r, 156r, 162r, 168r, 174r, 192r, 198r, 210r, 216r, 222r, 228r, 234r, 240r, 250r, 268r, 280r; no. 5A, fol. 9r, 15r, 20r, 26r, 32r, 44r, 50r, 68r, 86r, 92r, 98r; Série VII 1284-1285: Pièces concernant les finances de la ville de Strasbourg, comptes de la ville (1681-1802), no. 1284, fol. 34r ; no. 1285, fol. 67r; Série VII 1496-99: Hauptgutbücher I-V, 4 vols. (1592-18. Jh.). No. 1496, Hauptgutbuch I, pp. 1-24, 27-41, 43-50, 53-61, 6372, 74-76, 79-102, 105-14, 116-26, 131, 134-53, 158-65, 168-80, 183-97, 199, 201-4, 206-7, 209-17, 219-22, 224-31, 235-41, 246-55, 257-8, 260, 262, 267-8, 275, 281-2, 287, 289, 290-2, 294, 296-7, 300-5, 308-9, 313-8, 327, 335, 341-2, 345, 348-9, 353-6, 359-60, $366,369,371-80,382,385-7,393,396,413,417,419,422,425,428,439,444,450$, $462,471,475,477,480,486,489-90,500,508,512,517,519,523,525-33,535-8,540-$ 55, 557-69, 572-601, 603-38, 641-79, 681, 684-721; no. 1497, Hauptgutbuch II, pp. 7267, 747, 753, 755, 764, 765-9, 774, 777, 784-5, 788-90, 793, 795-9, 801-4, 806-15, 817-9, 822, 824, 826-7, 831-2, 835-7, 839, 842-3, 845-77, 922-41, 1002-13, 1040-1; Série VII 1518: Registre des rentes viagères à Paris (Zinsbuch G). 1 vol. 1736-1751, pp. 1-6 ; Série VII 1553: Emprunts contractés par la ville (1708-1749), fol. 1-9, 13-29, 34-8, 41-52, 57r58r, 59r-61r, 62r, 63r, 64r, 66r, 67r, 68r, 69r, 70r, 71r, 72r, 74r, 75r, 79r, 81r, 83r.

s'Hertogenbosch: 19 interest rates on heritable annuities yielding 15 yearly means (15111546) and 28 interest rates on life annuities yielding 24 yearly means (1501-1566)

van Zuijlen, R.A. (ed.) 1863. Inventaris der Archieven van de Stad s'Hertogenbosch: chronologisch opgemaakt en de vornaamste gebeurtenissen bevattende. Stads Rekeningen van 1399 - 1800. 1ste Deel van 1399-1568. s'Hertogenbosch: W.C. van Heusden, pp. 57, 203, 223, 313, 333, 344, 351-2, 360, 382, 406, 428-9, 455, 459, 525, 539, 549, 558, 569, 575-6, 590, 621, 639, 676, 726, 746, 753. 
The Hague: 42 interest rates on heritable annuities yielding 41 yearly means (1569-1671) and 89 interest rates on life annuities yielding 85 yearly means (1576-1745)

Liesker, R. \& Fritschy, W. 2004. Gewestelijke financiën ten tijde van de Republiek der Verenigde Nederlanden. Deel 4: Holland (1572-1795). Rijks Geschiedskundige Publicatiën uitgegeven door het Instituut voor Nerderlandse Geschiedenis. Kleine Serie, Vol. 100. Den Haag: Instituut voor Nederlandse Geschiedenis. Table III.5.g.1, pp. 381-2.

Tournai: Five interest rates on life annuities yielding five yearly means (1269-1325)

Bigwood, G. 1925. Les Financiers d'Arras (suite). In Revue belge de philologie et d'histoire. Tome 4 fasc. 3, 379-421, here p. 400.

Desportes, P. 1979. Reims et les Rémois au XIIIe et XIVe siècles. Paris: Éditions A. \& J. Picard, p. 450.

Kopf, E. W. 1927. The early history of the annuity. In Proceedings of the Casualty Actuarial Society, XIII(28), 225-266, here p. 237.

Turin: 110 interest rates on heritable annuities yielding 56 yearly means (1627-1797) and 13 interest rates on life annuities yielding 8 yearly means (1681-1747)

Duboin, C. (ed.) 1818-1868. Raccolta per ordine di materie delle leggi, provvidenze, editti, manifesti ecc. pubblicati (negli Stati di Terraferma) dal principio dell'anno 1681 sino agli 8 Dicembre 1798, sotto il felicissimo dominio della Real Casa di Savoia, per servire di continuazione a quella del Senatore Borelli. Torino: Davico e Picco, Tomo 7, Vol. 9, p. 293; Tomo 20, Vol. 22, pp. 1266, 1289-95, 1300, 1318-19, 1324, 1327-29, 1332-33, 1337, 1345, 1349, 1351-2, 1357; Tomo 23, Vol. 25, pp. 333-6, 347-8, 350-1, 354-5, 370, 372-4, 376-8, 386-8, 396, 402-3, 423-7, 433, 438, 445-9, 454-5, 457, 460, 464, 481, 483, $489-90,492,495,498,511-2,516,524,526,528,530,534-5,537,539,542,545,550$, $552,557,565,582,584,611$. 
De Luca, G. 2008. Government debt and financial markets: exploring pro-cycle effects in northern Italy during the sixteenth and seventeenth centuries. In Piola Caselli, F. (ed.) Government Debts and Financial markets in Europe. London: Pickering and Chatto, pp. 45-66, here p. 46.

Einaudi, L. 1908. La Finanza Sabauda all'Aprirsi del Secolo XVIII e Durante la Guerra di Successione Spagnola. Torino: Società Tipografico-Editrice Nazionale, pp. 67, 180, 195, 198, 200-1, 208-10, 236, 443, 445, 447-8.

Felloni, G. 1971. Gli Investimenti Finanziari Genovesi in Europa tra il Seicento e la Restaurazione. Milan: Giuffrè Editore, pp. 332, 334.

Prato, G. 1908. La Vita Economica in Piemonte a Mezzo il Secolo XVIII. Torino: Società Tipografico-Editrice Nazionale, p. 402.

Prato, G. 1916. Problemi Monetari e Bancari nei Secoli XVII e XVIII. Torino: Società Tipografico-Editrice Nazionale, p. 84.

Storrs, C. 1999. War, Diplomacy and the Rise of Savoy 1690-1720. Cambridge: Cambridge University Press, p. 95.

Stumpo, E. 2007. Città, stato e mercato finanziario: il diverso ruolo del debito pubblico in Piemonte e in Toscana. In De Luca, G. and Moioli, A. (eds.) Debito Pubblico e Mercati Finanziari in Italia. Secoli XIII-XX. Roma: Franco Angeli, pp. 147-65, here p. 164.

Symcox, G. 1983. Victor Amedeus II: Absolutism in the Savoyard State 1675-1730. London: Thames and Hudson, p. 201.

Udine: Four interest rates on heritable annuities yielding four yearly means (1556-1578)

Tagliaferri, A. 1969. Struttura e Politica Sociale in una Comunità Veneta del '500 (Udine). Milano: Giuffrè Editore, pp. 169, 180-1. 
Utrecht: One interest rate on an heritable annuity yielding 1 yearly mean (1668)

Verstegen, S.W. 2006. Gewestelijke financiën ten tijde van de Republiek der Verenigde Nederlanden. Deel 5: Utrecht (1579-1798). Rijks Geschiedskundige Publicatiën uitgegeven door het Instituut voor Nerderlandse Geschiedenis. Kleine Serie, Vol. 105. Den Haag: Instituut voor Nederlandse Geschiedenis. Table III.5.44, p. 142.

Venice: 484 interest rates on heritable annuities (which include 307 secondary market yields computed with price data) yielding 201 yearly means (1285-1789) and 24 interest rates on life annuities yielding 12 yearly means (1538-1715)

Reale Commissione per la Pubblicazione dei Documenti Finanziari della Repubblica di Venezia (ed.) 1912. Bilanci generali della Repubblica di Venezia, Vol. I (976/1641). Venice: Premiato Stabilimento Grafico Visentini Cav. Federico, pp. 210-2, 550, 555-7.

Reale Commissione per la Pubblicazione dei Documenti Finanziari della Repubblica di Venezia (ed.) 1903. Bilanci generali della Repubblica di Venezia, Vol. II. (1736/55). Venice: Premiato Stabilimento Grafico Visentini Cav. Federico, pp. 90-108, 191, 256, $433,435,456,478,482,485-6,495-6,501,532,555-68,575$.

Einaudi, L. 1907. L'Economia Pubblica Venziana dal 1735 al 1755. In Einaudi, L. (ed.) Studi di Economia e Finanza. Roma e Torino: Società Tipografico-Editrice Nazionale, pp. 115-207, here pp. 173-5.

Felloni, G. 1971. Gli Investimenti Finanziari Genovesi in Europa tra il Seicento e la Restaurazione. Milano: Dott. A. Giuffrè Editore, pp. 138-40, 146, 148, 154.

Gallicciolli, G. 1795. Delle Memorie Venete Antiche. Libro I, Tomo II. Venice: Appresso Domenico Fracasso, p. 91. 
Homer, S. and Sylla, R. E. 2005. A History of Interest Rates. $4^{\text {th }}$ ed. Hoboken, N. J.: Wiley, p. 107.

Luzzatto, G. 1961. Il Debito Pubblico della Repubblica di Venezia dagli Ultimi Decenni del XII Secolo alla Fine del XV. Milan: Istituto Editoriale Cisalpino, pp. 129-131, 271-272.

Mueller, R. C. 1997. The Venetian Money Market. Banks, Panics, and the Public Debt, 12001500. Baltimore and London: John Hopkins University Press, 474-475.

Pezzolo, L. 2003a. Il Fisco dei Veneziani. Finanza Pubblica ed Economia tra il XV e XVII Secolo. Verona: Cierre Edizioni, p. 84.

Pezzolo, L. 2003b. La Finanza Pubblica Veneziana in Età Moderna. Venezia: Università Cà Foscari di Venzia, pp. 47, 49, appendix.

Pezzolo, L. 2006. Una Finanza d'Ancien Régime la Repubblica Veneta tra XV e XVIII Secolo. Naples and Rome: Edizioni Scientifiche Italiane, pp. 90-1.

Pullan, B. S. 1971. Rich and Poor in Renaissance Venice: The Social Institutions of a Catholic State, to 1620. Cambridge, MA: Harvard University Press, p. 140.

Vietti, A. 1884. Il Debito Pubblico nelle Provincie che hanno formato il Primo Regno d'Italia Secondo i Documenti del R. Archivio di Stato Lombardo. Milano: Emilio Quadrio Editore, pp. 129, 131-2.

Archivio di Stato di Venezia [State Archives of Venice]:

Consiglio dei Dieci, Comune: r. 12, pp. 152, 158-9, 190, 201; Consiglio dei Dieci, Zecca: r. 1 , pp. $6-8,10,12,14-6,18-9,23-4,27,29,31,33,36-7,39,43,45-7,49-50,52-3,79-80$, $85,87,90,114,131$; r. 2 , pp. $51-53$; r. 3, pp. $90,93,95-6,100,107-11,113,115-8,121-$ 4, 126-7, 129-31, 133-48, 151, 153-4, 157-9, 161-6, 171-2, 174, 181-2, 187, 189, 200; 
Savio Cassier, busta 587: decreto 7 Maggio 1787; proclama 23 Maggio 1789; Senato, Zecca, 1608-1626: pp. 101-8, 110, 115-7, 122, 126, 132-4, 145, 194.

Verona: 466 interest rates on heritable annuities yielding 281 yearly means (1490-1797)

Ferlito, C. 2009. Il Monte di Pietà di Verona e il Contesto Economico-sociale della città nel Secondo Settecento. Venezia: IVSLA, p. 154-7.

Pulin, F. 1985. Il Monte di Pietà di Bassano (1492-1797). Vicenza: Edizioni L.I.E., p. 116.

Verviers: 13 interest rates on heritable annuities yielding five yearly means (1708-1795)

Bovy-Lenaux, F. 1975. Les depenses de la ville de Verviers au XVIIIe siècle. In In Finances Publiques d'Ancien Régime. Finances Publiques Contemporaines en Belgique de 1740 à 1860. Processus de Mutation Continuités et Ruptures. Colloque international, Spa, 19-22 December 1972. Bruxelles: Credit Communal de Belgique, pp. 175-188, here pp. 181, 188.

Nautet, G. J. 1859. Notices Historiques sur le Pays de Liege. Verviers: Typographie G. Nautet Hans, pp. 180-1.

Vicenza: One interest rate on an heritable annuity yielding one yearly mean (1493)

Pulin, F. 1985. Il Monte di Pietà di Bassano (1492-1797). Vicenza: Edizioni L.I.E., p. 113.

Vienna: 575 interest rates on heritable annuities yielding 59 yearly means (1443-1612) and 4 interest rates on life annuities yielding 4 yearly means (1439-1461)

Brunner, O. 1929. Die Finanzen der Stadt Wien von den Anfängen bis ins 16. Jahrhundert, Wien.

Urkunden zur Geschichte der Stadt Wien: Vol. I/3, no. 2378; vol. II/2, nos. 3450, 3560, 3715; vol. II/3, nos. 3793, 3856, 4097, Anhang XXXIX, Anhang XL; vol. II/4, no. 5539.

Stadt- und Landesarchiv Wien [Vienna - City and Provincial Archives]: 
Reihe - Rechnungen: Jahresrechnungsabschluss: Reinschriften (1424-1768): Vol. 8, fol. 7r; vol. 9, fol. 8r; vol. 13, fol. 14r; vol. 15, fol. 14r; vol. 16, fol. 7r; vol. 17, fol. 7v; vol. 18, fol. 10r; vol. 19, fol. 8r; vol. 25, fol. 7r; vol. 35, fol. 3v; vol. 69, fol. 18r; vol. 89, fol. 129r, 130r-v; vol. 90, fol. 107r; vol. 94, fol. 126v-127r; vol. 95, fol. 105r-106r, 112r-v; vol. 96, fol. 103r, 104r; vol. 97, fol. 132v-133r, 134r, 139r-v; vol. 98, fol. 136r139v, 142r-143r,145r-v,151v-152v, 157v-158v; vol. 99, fol. 60v-66r; vol. 100, fol. 84v101v; vol. 101, fol. 78v-87r; vol. 102, fol. 70r-80v; vol. 103, fol. 103v-112r; vol. 104, fol. 128r-137r; vol. 105, fol. 116r-128r; vol. 106, fol. 188r-205r; vol. 107, fol. 53r-61r; vol. 108, fol. 41v-56r; vol. 109, fol. 44r-55r; vol. 110, 102r-113v; vol. 111, 68v-78r; vol. 112, fol. 143r-147v; vol. 113, fol. 85v, 87r, 89v-91v; vol. 114, fol. 50v-52r, 55r, 57v-58r; vol. 115 , fol. $36 \mathrm{r}-41 \mathrm{v}, 48 \mathrm{v}, 49 \mathrm{v}$; vol. 116 , fol. 58v, 59v, 62r-64r; vol. 117, fol. 73v-75v, 78v-81v; vol. 118, fol. 71v-75r, 76r, 78r; vol. 119, fol. 64r, 65r, 76r-v; vol. 120, fol. 64v65r, 67v-70v, 72v-76r; vol. 121, fol. 62r-v, 64r-79v; vol. 122, fol. 113r; vol. 123, fol. 86r, 99v, 100v; vol. 124, fol. 135v-136r, 139v, 142r; vol. 126, fol. 103v; vol. 127, 77v; vol. 128, fol. 94r; vol. 129, fol. 63r-64v; vol. 130, fol. 77r; vol. 135, fol. 15v-16v, 18r; vol. 138, fol. 12 r.

Vigevano: Three interest rates on heritable annuities yielding three yearly means (16181669)

Caizzi, B. 1955. Economia e finanza a Vigevano nel cinque e nel seicento. In Nuova Rivista Storica, 3, 355-374, here pp. 371-3.

Wesel: Five interest rates on heritable annuities yielding five yearly means (1350-1450) and 153 interest rates on life annuities yielding 33 yearly means (1349-1450)

Espinas, G. 1902. Les finances de la commune de Douai, des origines au XVe siècle. Paris: Picard, pp. 321, 329. 
Gorissen, F. (ed.) 1963-1968. Stadtrechnungen von Wesel 1349-1450. Regesten zur politischen Geschichte des Niederrheins. 5 vols. Bonn: Hanstein. Vol. 1 (1349-1375), pp. 55-6; vol. 2 (1376-1400), pp. 80-2; vol. 3 (1401-1425), p. 41; vol. 4 (1426-1450), p. 39.

Wetzlar: One interest rate on a life annuity yielding one yearly mean (1361)

Historisches Archiv Wetzar [Wetzlar Archives]:

Urkunden 1361 Marz 30 (2).

Wismar: 261 interest rates on heritable annuities yielding 94 yearly means (1694-1729) and two interest rates on life annuities yielding 2 yearly means (1418-1561)

Stadtarchiv Wismar [Wismar City Archives]:

Ratsakten Nr. 2727 Schuldverschreibungen der Stadt (1634-1757). Enthält: Schuldverschreibungen der Nummern 1-10, 13, 17, 19, 27-29, 33-42, 44-50, 54-58, 6072, 86, 88, 90, 92-103, 105-111, 113-127, 129-135, 139-142, 148, 151-179, 181-190, 193-196, 198-213, 218-254, passim; Ratsakten Nr. 2727/1-6 Schuldverschreibungen der Stadt. No. 1 (1418-1600), passim; no. 2 (1606, 1617, 1622, 1623), passim; no. 3 (1625, 1646, 1647, 1651, 1656), passim; no. 4, für die Gebäude der Nikolaikirche (1658, 1661), passim; no. 5, für den Kirchenziegelhof zu St. Marien (1618-1659); Ratsakten Nr. 2897 Kämmereisachen: 1583/84; Ratsakten Nr. 2898 Kämmereisachen: 1662, 1663, 1664; Urkunden I: Weltliche Urkunden. Nos. 66, 115.

Worms: 85 interest rates on heritable annuities yielding 33 yearly means (1482-1758)

Stadtarchiv Worms [Worms City Archives]:

Abt. 1B: No. 1252a, Manuale der grossen Rechnung, 1614, fol. 21r; Abt. 1B: No. 1424/1-3, Sammlung der Verzeichnisse der Stadt Worms bei kaiserl. Kommision ausgezeigten Schulden (1690 - 1790); Abt. 1B: No. 1428/1-2, Sammlung aller bei den 
Moratorienakten gefundenen Verzeichnisse hiesiger Stadtschulden; Verzeichnis der mit Gläubigern der Stadt Worms getroffenen Vergleiche (1690 - 1790).

Würzburg: 129 interest rates on heritable annuities yielding 46 yearly means (1551-1709) and 51 interest rates on life annuities yielding 17 yearly means (1415-1465)

Stadtarchiv Würzburg [Würzburg City Archives]:

Bestand Ratsbücher. Ratsbuch 44, fol. 3, 10, 30, 54-63, 65, 67-9, 72-3, 75-7, 80-3; Ratsbuch 46, fol. 5-6, 11, 15, 17, 19-21, 27, 30, 32-3, 35, 41, 44, 51, 54, 56, 60, 64, 67, 99, 102, 104, 108, 129, 132, 140, 143, 147, 163, 170, 172; Ratsbuch 47, fol. 1-9, 13-7, $20-9,31-3,36-44,48-9,52-4,56-7,59,61,63-4,66,76,82,86-7,90,92,94-5,98,103-$ 4, 113; Ratsbuch 50, fol. 376, 381; Ratsbuch 51, fol. 375.

Zürich: One interest rate on a heritable annuities yielding one yearly mean (1404)

Fryde, E. B. and Fryde, M. M. 1963. Public Credit, with Special Reference to North-Western Europe. In Postan, M., Rich, E. E. and Miller, E. (eds.) The Cambridge Economic History of Europe: III: Economic Organization in the Middle Ages. Cambridge: Cambridge University Press, pp. 430-553, here p. 551.

Zutphen: One interest rate on an heritable annuities yielding one yearly mean (1446) and one interest rate on a life annuity yielding one yearly mean (1451)

Van Schaïk, R. 2003. The sale of annuities and financial politics in a town in the Eastern Netherlands Zutphen, 1400-1600. In Boone, M., Davids, K., and Janssens, P. (eds.) Urban Public Debts: Urban Government and the Market for Annuities in Western Europe (14th-18th Centuries). Turnhout: Brepols Publishers, pp. 109-126, here pp. 112, 118.

Zwolle: 96 interest rates on heritable annuities yielding 94 yearly means (1616-1795) and 64 interest rates on life annuities yielding 64 yearly means (1629-1794) 
Fritschy, W. 1996. Gewestelijke financiën ten tijde van de Republiek der Verenigde Nederlanden. Deel 1: Overijssel (1604-1795). Rijks Geschiedskundige Publicatiën uitgegeven door het Instituut voor Nerderlandse Geschiedenis. Kleine Serie, Vol. 86. Den Haag: Instituut voor Nederlandse Geschiedenis. Table III.5.40, pp. 213-224.

\section{Online Appendix B: Clustering Technique}

Model-based clustering with an ultrametric space is a technique to identify groups of nodes in a network (groups of cities and their hinterlands ${ }^{1}$ in our case) that are linked by a tie (in our case capital flows) (Schweinberger and Snijders 2003). It assumes that observed links are the product of a stochastic process. It is particularly suited to our context since this method identifies clusters across various levels of network intensity and thus it makes it possible to fully exploit the information provided by capital flows.

The likelihood that we recorded all the links between cities in the sample increases with the number of observations on imports per city. This implies that it is desirable to include in the analysis only relatively well-covered cities, or else we are bound to miss a non-trivial number of existing links. Yet, the fewer cities are included, the smaller is the area covered by the analysis. With this trade-off in mind, we focus on the 28 cities for each of which we have at least 10 observations on investments made from other cities and their hinterlands.

For robustness, we re-run the analysis with the following two other samples: one with the 12 cities with at least 80 observations on imports and one with all the 210 places named in the

\footnotetext{
A place is considered to belong to the hinterland of the closest other place that had at least 5000 inhabitants at some point in time during the period covered here (1228 to 1802). Using links between places instead worsens the results as the adjacency matrix becomes too sparse. In most cases, the distance between the hinterland-place and its 'central' town is small: less than $20 \mathrm{~km}$ in 85 per cent of the cases, and $70 \mathrm{~km}$ at most.
} 
sources. As an example, Figure B.1 below shows the geographical origins of foreign investors for the sample of the 12 cities with the best data coverage. Although this sample is biased towards North Germany, it includes important centres from other areas and mitigates the negative bias on the connectivity implied by failure to record existing links. In addition, to investigate possible changes in the clusters over time, we also run the analysis including only observations from before 1520 and from 1520 onwards, for cities with at least 10 observations on imports.

$<$ Figure B.1 about here >

Recorded capital flows between linked cities are bound to increase with their numbers of observations. This sample bias is econometrically addressed by regressing capital flows between city-pairs against the log of the sum of their numbers of observations on imports, using a negative-binomial specification. We use this technique because count regressions have desirable properties for estimating the determinants of bilateral flows (they do not suffer from the bias created by the logarithmic transformation and from the failure of the homoscedasticity assumption) and over-dispersion turns out to be a problem, thus cautioning against the use of a Poisson specification (Burger, Van Oort and Linders 2009). The capital flows that would have taken place if all linked cities were evenly covered are then estimated with the residuals. These are subsequently normalised to take values between 0 and 1 . Hence, our measure of network intensity is capital flows compared to that of the pair with the highest value: This is Lübeck-Lüneburg, where we find that capital flows (18,799 consumption baskets) were 17,514 consumption baskets greater than expected on the basis of their combined coverage (698 observations).

The model assumes that links within a cluster are symmetric and that clusters are not overlapping at any given level of capital flows. These assumptions are bound to be violated to some extent. However, they are shared by other clustering procedures and imply that groups 
are identified where the assumption of direct arbitrage between cities is closely approximated. Clusters can be identified either with a maximum likelihood or a Bayesian estimator. While the Bayesian estimator provides a more elegant model selection procedure, it yields in the present case unstable and occasionally implausible settings that suggest a poor fit with the data. We therefore use the maximum likelihood estimator. As our measure of strength is continuous, we assume a Gaussian distribution. To investigate possible nonconvergence, we run ten sequences. Given that there are 28 cities in the main sample we allow up to seven different levels of clustering. The results are reported in Table B.1, where the second to the seventh columns report the expected network intensity at each clustering level for each total number of levels.

<Table B.1 about here>

The log-likelihood function is maximised when we assume seven different levels, but the difference is big only when compared to a total of two or three levels. Inspection of the output reveals that non-convergence may be an issue, as evidenced by unstable maxima of the log-likelihood function, when we assume that there were five levels or more. Moreover, the results are qualitatively very similar for four to six levels: All detect very close values at levels 1 to 3 and sharp drops in network intensity subsequently. Hence, no important information is lost by only considering four levels, and we therefore present this model in the paper. The only new result emerging from the robustness checks is that enlarging the sample reveals a wide cluster around Nuremberg, which developed strong links with Salzburg and Maribor.

\title{
Online Appendix C: Supplementary Figures
}

\author{
$<$ Figure C. 1 here >
}


$<$ Figure C.2 here >

\section{References}

\section{Archival sources}

ASF (Archivio di Stato di Firenze), Monte Comune o delle Graticole, parte I, pezzo 3.

Staatsarchiv Nürnberg, Bestand: Losungsamt Vol. 69.

Stadtarchiv Braunschweig, B I 11 Leibgedingebücher, vol. 4.

Regionaal Archief Dordrecht (formerly, Gemeente Archiev Dordrecht‘), GAD 1, no. 434.

Stadtarchiv Erfurt, 1-1/21 10 Libri ordinationum, vol. 1; Obligationen; 2 Hauptrechnungen.

Stadtarchiv Hannover, NAB 7228; NAB 8242, Stadtobligationsbuch 1387-1533; NAB 7228, Urkunden Abteilung 3 - Schuldurkunden des Rates.

Stadtarchiv Lüneburg, AB 55 Kopie von Rentenbriefen (1441-1492).

Landeshauptarchiv Magdeburg, Copiar der Obligationen der Stadt Halle, Cop. 395a; Cop.

Stadtarchiv Münster, Ratsarchiv A IX, Findbuch zu den Rentenverschreibungen aus Abt. A IX des ,Alten Archivs', no. 43.396.

Archives de la ville Strasbourg, Série IV, No. 71.

Published primary and secondary sources

Allen, Robert C. "The Great Divergence in European Prices and Wages from the Middle Ages to the First World War." Explorations in Economic History 38, no. 4 (2001): 411447.

Albers, Hermann. "Die Anleihen der Stadt Bremen vom 14. bis zum 18. Jahrhundert." Veröffentlichungen aus dem Staatsarchiv der freien Hansestadt Bremen 3 (1930): 1163. 
Alter, George and Riley, James C. "How to Bet on Lives: A Guide to Life Contingent Contracts in Early Modern Europe." Research in Economic History 10 (1986): 1-53. Álvarez Nogal, Carlos. Oferta y demanda de deuda pública en Castilla: Juros de Alcabalas (1540-1740). Madrid: El Banco de España, 2009.

Angermeier, Heinz. Die Reichsreform 1410-1555: die Staatsproblematik in Deutschland zwischen Mittelalter und Gegenwart. Munich: Beck, 1984.

Bateman, Victoria N. "The Evolution of Markets in Early Modern Europe, 1350-1800: A Study of Wheat Prices". Economic History Review 64, no. 2 (2011): 447-471.

Bateman, Victoria N. Markets and Growth in Early Modern Europe. London: Pickering \& Chatto, 2012.

Baum, Hans-Peter. “Annuities in Late Medieval Hanse Towns.” Business History Review 59, no. 1 (1985): 24-48.

Behringer, Wolfgang. "Core and Periphery: The Holy Roman Empire as a Communication(s) Universe.” In The Holy Roman Empire 1495-1806, ed. by Evans, R. J. W., Schaich, M. and Wilson, P. H., 347-358. Oxford: Oxford University Press, 2011.

Braudel, Fernand. Civilization and Capitalism, $15^{\text {th }}-18^{\text {th }}$ Centuries, Vol. III: The Perspective of the World. Oakland, CA: University of California Press, 1982.

Boerner, Lars and Ritschl, Albrecht. "Individual Enforcement and Collective Liability in Premodern Europe: A Comment," Journal of Institutional and Theoretical Economics 158, no. 1 (2002): 205-213.

Brown, Edward. An Account of Several Travels Through a Great Part of Germany: In Four Journeys. I. From Norwich to Colen. II. From Colen to Vienna, with a Particular Description of that Imperial City. III. From Vienna to Hamburg. IV. From Colen to London. Wherein The Mines, Baths, and Other Curiosities of those Parts are Treated of. Illustrated with Sculptures. London: Benj. Tooke, 1677. 
Brown, Jeffrey A. et al. The Role of Annuity Markets in Financing Retirement. Cambridge/MA: MIT Press, 2001.

Calabria, Antonio. The Cost of Empire: The Finances of the Kingdom of Naples in the Time of Spanish Rule. Cambridge: Cambridge University Press, 1991.

Chilosi, David. "Risky Institutions: Political Regimes and the Cost of Public Borrowing in Early Modern Italy”. Journal of Economic History 74, No. 3 (2014): 887-915.

Day, John. "Money and Credit in Medieval and Renaissance Italy", The Medieval Market Economy, ed. by ibid., 141-161. Oxford: Basil Blackwell, 1987.

Denzel, Markus A. Das System des bargeldlosen Zahlungsverkehrs europäischer Prägung vom Mittelalter bis 1914. Stuttgart: Steiner, 2008.

De Luca, Giuseppe. "Debito pubblico, mercato finanziario ed economia reale nel Ducato di Milano e nella Repubblica di Venezia tra XVI e XVII secolo", Debito Pubblico e Mercati Finanziari in Italia. Secoli XIII-XX, edited by G. De Luca, and A. Moioli, 118146. Rome: Franco Angeli, 2007.

De Vries, Jan. The Economy of Europe in an Age of Crisis, 1600-1750. Cambridge: Cambridge University Press, 1976.

Distler, Eva-Maria. Städtebünde im deutschen Spätmittelalter: Eine rechtshistorische Untersuchung zu Begriff, Verfassung und Funktion. Frankfurt: Vittorio Klostermann, 2006.

Dollinger, Philippe. Die Hanse. 3 ed. Stuttgart: Kröner, 1981.

Epstein, Stephan R. Freedom and Growth: The Rise of States and Markets in Europe, 13001750. London and New York: Routledge, 2000.

Federico, Giovanni. "How Much do we Know about Market Integration in Europe?”. Economic History Review 65, No. 2 (2012), 470-497. 
Federico, Giovanni, Schulze Max-Stephan and Volckart, Oliver. "European Goods Market Integration Over the Very Long-Run: From the Black Death to the First World War". Mimeo, 2018.

Feenstra, Alberto. "Keeping the Ship of State Afloat: Zeeland's Sovereign Debt Management, 1600-1800”. Paper presented at the Leiden International Conference in Political History, 2014.

Felloni, Giuseppe. Gli Investimenti Finanziari Genovesi in Europa tra il Seicento e la Restaurazione. Milan: Giuffrè Editore, 1971.

Felloni, Giuseppe. “Dall’Italia all'Europa: il primato della finanza italiana dal medioevo alla prima età moderna", Storia d'Italia, Annali 23, La Banca, edited by Alberto Cova, Salvatore La Francesca, Angelo Moioli et al., 91-149. Torino: Einaudi, 2008.

Flandreau, Marc and Flores, Juan H. "Bonds and Brands: Foundations of Sovereign Debt Markets”. Journal of Economic History 69, no. 3 (2009): 646-684.

Flandreau, Marc, Galimard, Christopher, Jobst, Clemens and Nogués-Marco, Pilar. "Monetary Geography before the Industrial Revolution". Cambridge Journal of Regions, Economy and Society 2, no. 2 (2009): 149-171.

Fratianni, Michele. “Government Debt, Reputation and Creditors' Protection: The Tale of S. Giorgio". Review of Finance 10, no. 4 (2006): 487-506.

Fryde, Edmund Boleslaw and Fryde, Matthew M. "Public Credit, with Special Reference to North-Western Europe.” The Cambridge Economic History of Europe, III: Economic Organization in the Middle Ages, edited by M. Postan, E. E. Rich and E. Miller, 430553 Cambridge: Cambridge University Press, 1963.

Fuhrmann, Bernd. ““Öffentliches` Kreditwesen in deutschen Städten des 15. und 16. Jahrhunderts.” Scripta Mercaturae 37 (2003): 1-17. 
Fuhrmann, Bernd. "Taxation and Debt in Early Modern German Cities." Taxation and Debt in the Early Modern City, edited by José Ignacio Andrés Ucendo and Michael Limberger, 181-196. London: Pickering \& Chatto, 2014.

Gabrielsson, Peter. Struktur und Funktion der Hamburger Rentengeschäfte in der Zeit von 1471 bis 1490: Ein Beitrag zur Wirtschafts- und Sozialgeschichte der nordwestdeutschen Stadt. Hamburg: Christians, 1971.

Gelderblom, Oscar and Jonker, Joost. "Completing a Financial Revolution: The Finance of the Dutch East India Trade and the Rise of Amsterdam Capital Market”. Journal of Economic History 64, no. 3 (2004), 641-672.

Gelderblom, Oscar and Jonker, Joost. "Public Finance and Economic Growth: The Case of Holland in the Seventeenth Century". Journal of Economic History 71, no. 1 (2011), 139.

Gilomen, Hans-Jörg. "Die städtische Schuld Berns und der Basler Rentenmarkt im 15. Jahrhundert”. Basler Zeitschrift für Geschichte und Altertumskunde 82 (1982), 5-64.

Gilomen, Hans-Jörg. Der Rentenkauf im Mittelalter. Habilitationsschrift, Universität Basel, 1984. Available at: http://www.hist.uzh.ch/fachbereiche/mittelalter/emeriti/gilomen/publikationen/Rentenk auf.pdf (accessed 5 November 2014).

Homer, Sidney and Sylla, Robert. E. A History of Interest Rates. $4^{\text {th }}$ ed. Hoboken, N. J.: Wiley, 2005.

Israel, Jonathan I. Dutch Primacy in World Trade, 1585-1740. Oxford: Clarendon Press, 1989.

Keller, Wolfgang, Shiue, Carol H. and Wang, Xin. "Capital Markets in China and Britain, 18th and 19th Century: Evidence from Grain Prices". Revised version (March 2016) of NBER Working Paper No. 21349, 2016. 
Kern, Bernd-Rüdiger, "Die landesherrliche Kontrolle über die Gemeindeverschuldung in frühneuzeitlichen Rechtsquellen.” Staatsfinanzen - Staatsverschuldung Staatsbankrotte in der europäischen Staaten- und Rechtsgeschichte, edited by G. Lingelbach. Cologne, 191-202. Weimar, Vienna: Böhlau, 2000.

Kleinehagenbrock, Frank. "Der Umgang mit Finanzkrisen im Heiligen Römischen Reich Modell für moderne föderale staatliche Ordnungen?" Staatsbankrott als Rechtsfrage, edited by K. von Lewinski, 59-76. Baden-Baden: Nomos, 2011.

Klinger, Jens (ed.). Das Dresdener Stadtbuch 1477-1495. Edition und Forschung (InauguralDissertation zur Erlangung der Doktorwürde der Philosophie, Kunst- und Gesellschaftswissenschaften der Universität Regensburg). Regensburg, 2011.

Kroeschell, Karl. "Stadtrecht, -sfamilien.” Lexikon des Mittelalters, vol. VIII: Stadt (Byzantinisches Reich) bis Werl, cols. 24 ff. Munich: dtv, 2003.

Malanima, Paolo. L'Economia Italiana: Dalla Crescita Medievale alla Crescita Contemporanea. Bologna: Il Mulino, 2002.

Malanima, Paolo. “The Long Decline of a Leading Economy: GDP in Central and Northern Italy, 1300-1913”. European Review of Economic History 15, no. 2 (2011): 169-219.

Masini, Roberta. "Gli investitori nei titoli di debito pubblico pontificio: categorie sociali, distribuzione delle quote, motivazioni di una scelta (XVII secolo).” Debito Pubblico e Mercati Finanziari in Italia. Secoli XIII-XX, edited by G. De Luca, and A. Moioli, 197214. Rome: Franco Angeli, 2007.

Michie, Ranald C. "The Invisible Stabiliser: Asset Arbitrage and the International Monetary System Since 1700”. Financial History Review 5, No. 1 (1998): 5-26.

Milhaud, Cyril. Fragmentation of Capital Markets in Early Modern Spain? Composite Monarchies and their Jurisdictions <hal-01365882>. 2016. Available at: https://hal.archives-ouvertes.fr/hal-01365882 
Mokyr, Joel. A Culture of Growth: The Origins of the Modern Economy. Princeton, Oxford: Princeton University Press, 2017.

Molho, Anthony. "The State and Public Finance: A Hypothesis Based on the History of Late Medieval Florence.” Journal of Modern History 67, Supplement (1995): 97- 135.

Moraw, Peter. Von offener Verfassung zu gestalteter Verdichtung: Das Reich im Späten Mittelalter 1250 bis 1490. Frankfurt, Berlin: Propyläen, 1989.

Munro, John H. "The Medieval Origin of the Financial Revolution: Usury, Rentes, and Negotiability." International History Review 25, no. 3 (2003): 505-62.

Munro, John H. "The Usury Doctrine and Urban Public Finances in Late-Medieval Flanders (1220-1550): Rentes, Excise Taxes, and Income Transfers from the Poor to the Rich", Paper presented to the Washington Area Economic History Seminar at the University of Maryland Baltimore County, 2007.

Neal, Larry. "Integration of International Capital Markets: Quantitative Evidence from the Eighteenth to the Twentieth Centuries". Journal of Economic History 45, no. 2 (1985): 219-226.

Neal, Larry. "The Integration and Efficiency of the London and Amsterdam Stock Markets in the Eighteenth Century". Journal of Economic History 47, no. 1 (1987): 97-115.

Neal, Larry. The Rise of Financial Capitalism. Cambridge: Cambridge University Press, 1994.

Neal, Larry. A Concise History of International Finance: From Babylon to Bernanke. Cambridge: Cambridge University Press, 2015.

Obstfeld, Maurice and Taylor, Alan M. Global Capital Markets: Integration, Crisis, and Growth. Cambridge: Cambridge University Press, 2004.

Ogilvie, Sheilagh C. "Germany and the Seventeenth-Century Crisis." Historical Journal 35, no. 2 (1992): 417-441. 
Pezzolo, Luciano. "Elogio della rendita : Sul debito pubblico degli stati italiani nel cinque e seicento." Rivista di Storia Economica 12, no. 3 (1995): 283-330.

Pezzolo, Luciano. "Bonds and Government Debt in Italian City-States, 1250-1650”, The Origins of Value: The Financial Innovations that Created Modern Capital Markets edited by William N. Goetzmann, N. and K. Geert Rouwenhorst, 145-64. Oxford and New York: Oxford University Press, 2005.

Pezzolo, Luciano and Tattara, Giuseppe. “'Una fiera senza luogo’: was Bisenzone an international capital market in sixteenth-century Italy?” Journal of Economic History 68, no. 4 (2008): 1098-1122.

Poitras, Geoffrey. "Life Annuity Valuation: From de Witt and Halley to de Moivre and Simpson." Pioneers of Financial Economics: Contributions prior to Irving Fisher, edited by ibid., 79-99. Cheltenham, Northampton/MA: Elgar, 2006.

Press, Volker. "Die Niederlande und das Reich in der Frühen Neuzeit”, Etat et Religion aux XVe et XVIe Siècles: Actes du Colloque à Bruxelles du 9 au 12 Octobre 1984, edited by Wim P. Blockmans and Herman van Nüffel, 321-338. Bruxelles: Archives générales du Royaume de Belgique, 1986.

Press, Volker. Kriege und Krisen: Deutschland 1600-1715. Munich: Beck, 1991.

Pugliese, Salvatore. "Condizioni economiche e finanziarie della Lombardia nella prima metà del secolo XVIII." Miscellanea di Storia Italiana, Terza Serie, Tomo XXI, 1-495. Turin: Fratelli Bocca Librai di S. M., 1924.

Quarthal, Franz. "Verfassung und Verwaltung in südwestdeutschen Städten der Frühen Neuzeit." Recht, Verfassung und Verwaltung in der frühneuzeitlichen Stadt, edited by Michael Stolleis, 217-239. Cologne: Böhlau, 1991.

Roeck, Bernd. Als die wollt die Welt schier brechen: Eine Stadt im Zeitalter des Dreißigjährigen Krieges. Munich: Beck, 1991. 
Rosen, Josef. “Zins und Zinsaufwand in Basel 1360-1535.” Wirtschaftskräfte und Wirtschaftswege: Festschrift für Hermann Kellenbenz, vol. 1: Mittelmeer und Kontinent, edited by Jürgen Schneider, 179-202. Stuttgart: Klett-Cotta, 1978.

Schiavo, Stefano, Reyes, Javier and Fagiolo, Giorgio. "International Trade and Financial Integration: A Weighted Network Analysis." Quantitative Finance 10, no. 4 (2010): 389-399.

Schmidt, Georg. "The State and the Nation of the Germans." The Holy Roman Empire: 14951806, edited by R.J.W. Evans, M. Schaich and Peter H. Wilson, 43-62. Oxford: Oxford University Press, 2011.

Schubert, Eric S. “Arbitrage in the Foreign Exchange Markets of London and Amsterdam during the 18th Century." Explorations in Economic History 26 (1989): 1-20.

Schultze, Alfred. "Über Gästerecht und Gastgerichte in den deutschen Städten des Mittelalters." Historische Zeitschrift 101 (1908): 473-528.

Schweinberger, Michael and Snijders, Tom A.B. "Settings in Social Networks: A Measurement Model.” Sociological Methodology 33, no. 1 (2003): 307-41.

Sieveking, Heinrich. "Studio sulle finanze genovesi nel Medioevo e in particolare sulla Casa di S. Giorgio". Translated by Onoro Soardi. Atti della Società Ligure di Storia Patria 35, No. 1. 1905.

Sprandel, Rolf. "Der städtische Rentenmarkt in Nordwestdeutschland im Spätmittelalter." Öffentliche Finanzen im späten Mittelalter und in der ersten Hälfte des 19. Jahrhunderts, edited by Hermann Kellenbenz, 14-23. Stuttgart: Fischer, 1971.

Spruyt, Hendrik. The Sovereign State and its Competitors. Princeton, New Jersey: Princeton University Press, 1994.

Stasavage, David. States of Credit: Size, Power, and the Development of European Polities. Princeton: Princeton University Press, 2011. 
Stumpo, Enrico "Città, stato e mercato finanziario: il diverso ruolo del debito pubblico in Piemonte e in Toscana.” Debito Pubblico e Mercati Finanziari in Italia. Secoli XIII-Ü, edited by G. De Luca and A. Moioli, 147-165. Rome: Franco Angeli, 2007.

Sylla, Richard. "Financial Systems and Economic Modernization". Journal of Economic History 62, no. 2 (2002): 277-292.

Tracy, James D. "On the Dual Origins of Long-Term Urban Debt in Medieval Europe.” Urban Public Debts: Urban Government and the Market for Annuities in Western Europe (14th - 18th centuries), edited by Marc Boone, Karel Davids and Paul Janssens, 13-24. Tournhout: Brepols, 2003.

Van der Heijden, Manon. "State Formation and Urban Finances in Sixteenth- and Seventeenth-Century Holland.” Journal of Urban History 33, no. 3 (2006): 429-450.

Volckart, Oliver. "Politische Zersplitterung und Wirtschaftswachstum im Alten Reich, ca. 1650-1800." Vierteljahrschrift für Sozial- und Wirtschaftsgeschichte 86, no. 1 (1999): $1-38$.

Volckart, Oliver. Wettbewerb und Wettbewerbsbeschränkung im vormodernen Deutschland 1000-1800. Tübingen: Mohr-Siebeck, 2002.

Westphal, Siegrid. Kaiserliche Rechtsprechung und herrschaftliche Stabilisierung: Reichsgerichtsbarkeit in den thüringischen Territorialstaaten 1648-1806. Cologne and Weimar: Böhlau, 2002.

Wüst, Wolfgang. Die „gute“ Policey im Fränkischen Reichskreis. Berlin: Akademie-Verlag, 2003.

Zuijderduijn, C. Jaco. Medieval Capital Markets: Markets for Renten, State Formation and Private Investment in Holland (1300-1550). Leiden and Boston: Brill, 2009. 
Table 1: Observations by source type and annuity type

\begin{tabular}{lcccccc}
\hline Annuity Type & \multicolumn{3}{c}{ Heritable Annuity } & \multicolumn{4}{c}{ Life Annuity } & Total \\
\hline Source Type & Empire & $\begin{array}{c}\text { Italy } \\
\text { (primary market) }\end{array}$ & $\begin{array}{c}\text { Italy } \\
\text { (forced loans) }\end{array}$ & Empire & Italy \\
\hline Letters & 1 & 3 & 4 & 5 & 6 & 7 \\
Ledgers & 9,179 & 0 & 0 & 1,422 & 0 & 10,601 \\
Urban Accounts & 6,344 & 518 & 0 & 717 & 2 & 7,581 \\
Edicts & 5,001 & 0 & 0 & 2,820 & 0 & 7,821 \\
Secondary sources & 49 & 466 & 0 & 11 & 67 & 593 \\
\hline Total & 724 & 1,393 & 349 & 288 & 26 & 2,780 \\
\hline
\end{tabular}

Sources: Online Appendix A.

Table 2: Long term trends in capital market integration

\begin{tabular}{llcccccc}
\hline Sample & Asset & Years & $\begin{array}{c}\text { Sample } \\
\text { size }\end{array}$ & $\begin{array}{c}\text { Initial } \\
\text { spread }\end{array}$ & $\begin{array}{c}\text { Final } \\
\text { spread }\end{array}$ & $\begin{array}{c}\text { Yearly rate of } \\
\text { change*100 }\end{array}$ & $\begin{array}{c}\text { Cumulated } \\
\text { change*100 }\end{array}$ \\
\hline & & 1 & 2 & 3 & 4 & 5 & 6 \\
\hline All & Heritable annuity & $1315-1805$ & 5004 & 1.253 & 1.169 & $-0.014^{* * * *}$ & -6.63 \\
All & Life annuity & $1320-1794$ & 1412 & 1.142 & 1.081 & $-0.011^{* * * *}$ & -5.29 \\
Empire & Heritable annuity & $1344-1802$ & 3428 & 1.170 & 1.100 & $-0.014^{* * * *}$ & -6.00 \\
Empire & Heritable annuity & $1493-1802$ & 2637 & 1.137 & 1.104 & $-0.010^{* * *}$ & -2.93 \\
Empire & Life annuity & $1320-1794$ & 1330 & 1.144 & 1.065 & $-0.015^{* * *}$ & -6.97 \\
Italy & Heritable annuity & $1362-1800$ & 1439 & 1.329 & 1.255 & $-0.013^{* * *}$ & -5.52 \\
Italy & $\begin{array}{c}\text { Heritable annuity } \\
\text { (excl. forced loans) }\end{array}$ & $1493-1800$ & 1367 & 1.250 & 1.285 & $0.009^{*}$ & 2.79 \\
\hline
\end{tabular}

$*=$ Significant at 10 percent level; $* *=$ Significant at 5 percent level; $* * *=$ Significant at 1 percent level.

City fixed effects.

Sources: Online Appendix A. 
Table 3: Inter-city investment in the Empire: trends in average distance (in $\mathrm{km}$ ) and average capital invested (in consumption baskets)

\begin{tabular}{lcccccc}
\hline Variable & Years & $\begin{array}{c}\text { Sample } \\
\text { Size }\end{array}$ & $\begin{array}{c}\text { Yearly rate of } \\
\text { change*100 }\end{array}$ & $\begin{array}{c}\text { Cumulated } \\
\text { change*100 }\end{array}$ & Initial value & Final value \\
\hline Distance & 1 & 2 & 3 & 4 & 5 & 6 \\
Capital & $1228-1802$ & 1434 & $0.159 * * *$ & 148 & 47 & 116 \\
\hline
\end{tabular}

$*=$ Significant at 10 percent level; $* *=$ Significant at 5 percent level; $* * *=$ Significant at 1 percent level. Importer city fixed effects.

Sources: Online Appendix A.

Table 4: Integration of capital markets in the Empire: the role of distance (in km)

\begin{tabular}{ccccccc}
\hline Distance & $\begin{array}{c}\text { Sample } \\
\text { size }\end{array}$ & Years & $\begin{array}{l}\text { Yearly rate of } \\
\text { change*100 }\end{array}$ & $\begin{array}{l}\text { fitted pairwise } \\
\text { differentials at } \\
\text { start }\end{array}$ & $\begin{array}{l}\text { fitted pairwise } \\
\text { differentials at } \\
\text { end }\end{array}$ & $\begin{array}{l}\text { Cumulated } \\
\text { change*100 }\end{array}$ \\
\hline & 1 & 2 & 3 & 4 & 5 & 6 \\
\hline$<200$ & 6258 & $1333-1795$ & $-0.023^{* * *}$ & 1.225 & 1.100 & -10.181 \\
$>200$ & 15183 & $1320-1804$ & $-0.042^{* * *}$ & 1.360 & 1.109 & -18.435 \\
\hline
\end{tabular}

*=Significant at 10 percent level; $* *=$ Significant at 5 percent level; $* * *=$ Significant at 1 percent level. City-pair fixed effects.

Sources: Online Appendix A. 
Table 5: Integration of capital markets in the Empire: within and between clusters

Within integration

\begin{tabular}{|c|c|c|c|c|c|c|}
\hline & $\begin{array}{r}\text { sample } \\
\text { size }\end{array}$ & Years & $\begin{array}{l}\text { Yearly rate of } \\
\text { change* } * 100\end{array}$ & $\begin{array}{c}\text { Fitted } \\
\text { differential } \\
\text { at start }\end{array}$ & $\begin{array}{c}\text { Fitted } \\
\text { differential } \\
\text { at end }\end{array}$ & $\begin{array}{l}\text { Cumulated } \\
\text { change*100 }\end{array}$ \\
\hline & 1 & 2 & 3 & 4 & 5 & 6 \\
\hline Breisgau & 241 & $1396-1741$ & $-0.016^{*}$ & 1.093 & 1.035 & -5.318 \\
\hline Lower Saxony & 1591 & $1351-1750$ & $-0.022 * * *$ & 1.152 & 1.056 & -8.283 \\
\hline Upper Germany & 210 & $1388-1551$ & 0.023 & 1.092 & 1.133 & 3.764 \\
\hline Hessen & 108 & $1550-1760$ & -0.004 & 1.038 & 1.028 & -0.922 \\
\hline Upper Saxony & 61 & $1497-1621$ & 0.002 & 1.052 & 1.055 & 0.259 \\
\hline Westphalia & 236 & $1350-1760$ & -0.002 & 1.078 & 1.068 & -0.992 \\
\hline Northern Netherlands & 364 & $1520-1795$ & 0.002 & 1.082 & 1.087 & 0.499 \\
\hline Southern Netherlands & 167 & $1392-1775$ & $0.028 * * *$ & 1.027 & 1.143 & 11.218 \\
\hline \multicolumn{7}{|l|}{ Between integration } \\
\hline & $\begin{array}{r}\text { sample } \\
\text { size }\end{array}$ & Years & $\begin{array}{l}\text { Yearly rate of } \\
\text { change* } 100\end{array}$ & $\begin{array}{c}\text { Fitted } \\
\text { differential } \\
\text { at start } \\
\end{array}$ & $\begin{array}{c}\text { Fitted } \\
\text { differential } \\
\text { at end } \\
\end{array}$ & $\begin{array}{l}\text { Cumulated } \\
\text { change*100 }\end{array}$ \\
\hline Breisgau & 447 & $1383-1791$ & -0.008 & 1.136 & 1.101 & -3.081 \\
\hline Lower Saxony & 1653 & $1320-1804$ & $-0.004 *$ & 1.138 & 1.114 & -2.112 \\
\hline Upper Germany & 402 & $1382-1804$ & $-0.037 * * *$ & 1.255 & 1.071 & -14.611 \\
\hline Hessen & 232 & $1410-1797$ & -0.009 & 1.116 & 1.077 & -3.516 \\
\hline Upper Saxony & 196 & $1320-1698$ & -0.011 & 1.119 & 1.073 & -4.04 \\
\hline Westphalia & 415 & $1350-1780$ & -0.001 & 1.108 & 1.106 & -0.225 \\
\hline Northern Netherlands & 501 & $1422-1795$ & $-0.062 * * *$ & 1.389 & 1.100 & -20.771 \\
\hline Southern Netherlands & 346 & $1360-1795$ & $-0.060 * * *$ & 1.381 & 1.063 & -23.056 \\
\hline
\end{tabular}

$*=$ Significant at the 10 percent level; $* *=$ Significant at the 5 percent level; $* * *=$ Significant at the 1 percent level. City fixed effects.

Sources: Online Appendix A.

Table B.1: Network clustering: expected network intensity by level and number of levels

\begin{tabular}{cccc|c|cc}
\hline $\begin{array}{c}\text { Level } \\
\text { N. of levels }\end{array}$ & 7 & 6 & 5 & 4 & 3 & 2 \\
\hline 1 & 1.000 & 1.000 & 1.000 & 1.000 & 1.000 & 0.275 \\
2 & 0.476 & 0.364 & 0.364 & 0.364 & 0.206 & 0.013 \\
3 & 0.297 & 0.163 & 0.163 & 0.150 & 0.010 & \\
4 & 0.148 & 0.025 & 0.039 & 0.009 & & \\
5 & 0.009 & 0.005 & 0.008 & & & \\
6 & 0.009 & 0.000 & & & & \\
7 & 0.009 & & & & & \\
Log likelihood & -0.491 & -0.516 & -0.520 & -0.531 & -0.734 & -1.3191 \\
\hline Sources: Onlin Appen
\end{tabular}

Sources: Online Appendix A. 
Figure 1: Interest rate observations (yearly means), 1240-1809: geographical distribution a) Life annuities

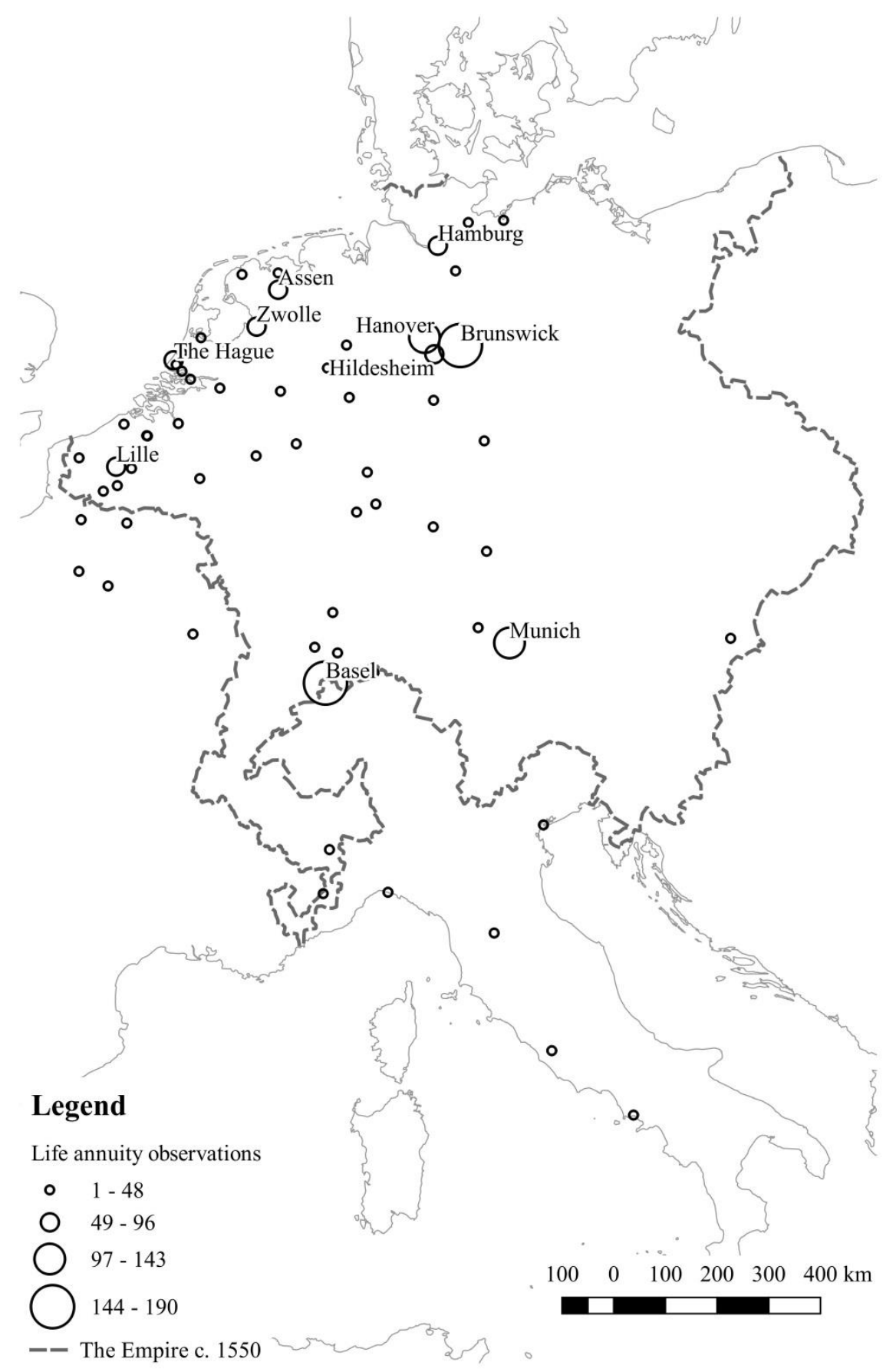


b) Heritable annuities

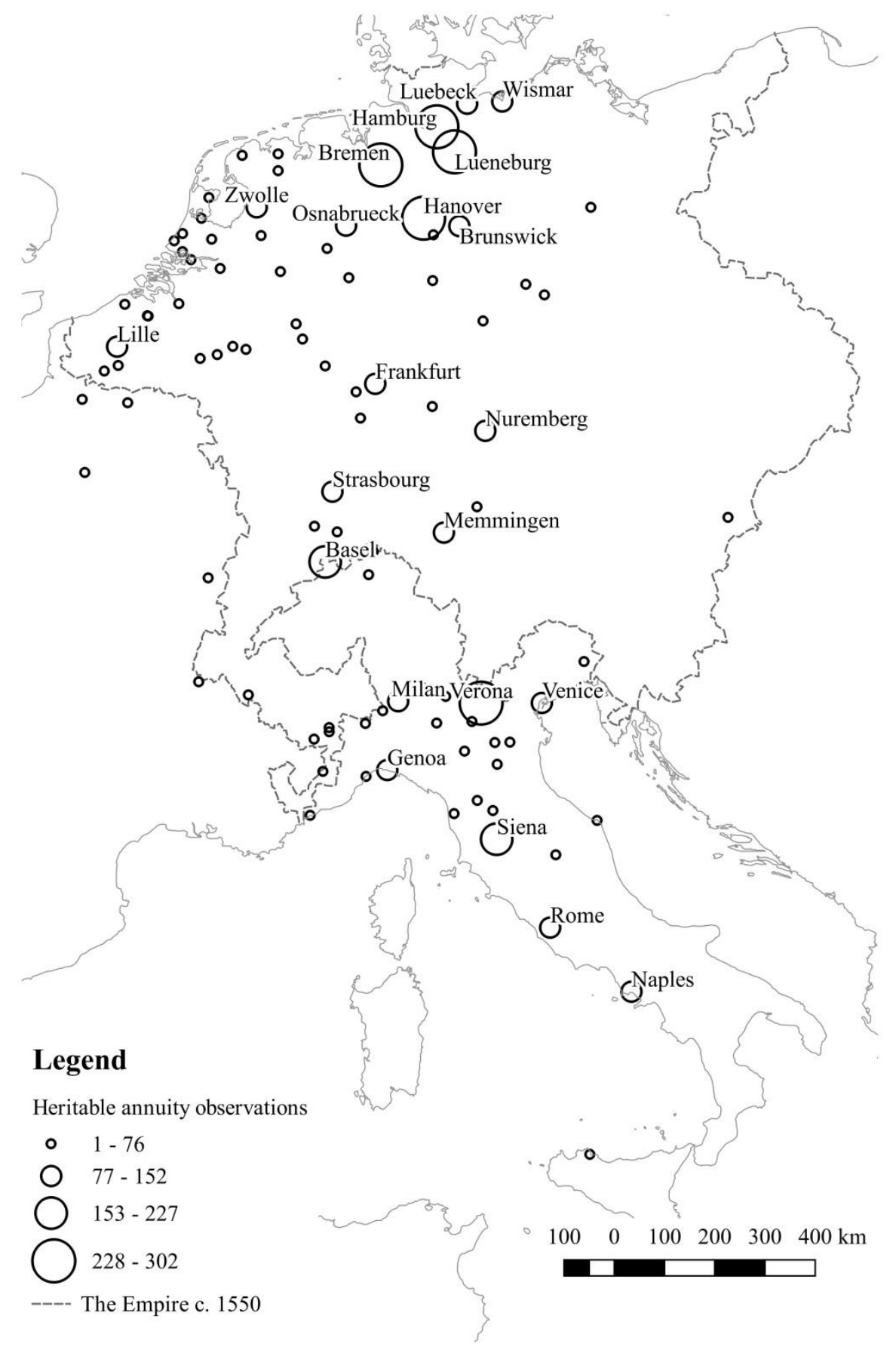

Sources: Online Appendix A. 
Figure 2: Nominal interest rates on heritable annuities in the Holy Roman Empire and Italy, 1263-1809 (yearly means, in per cent)

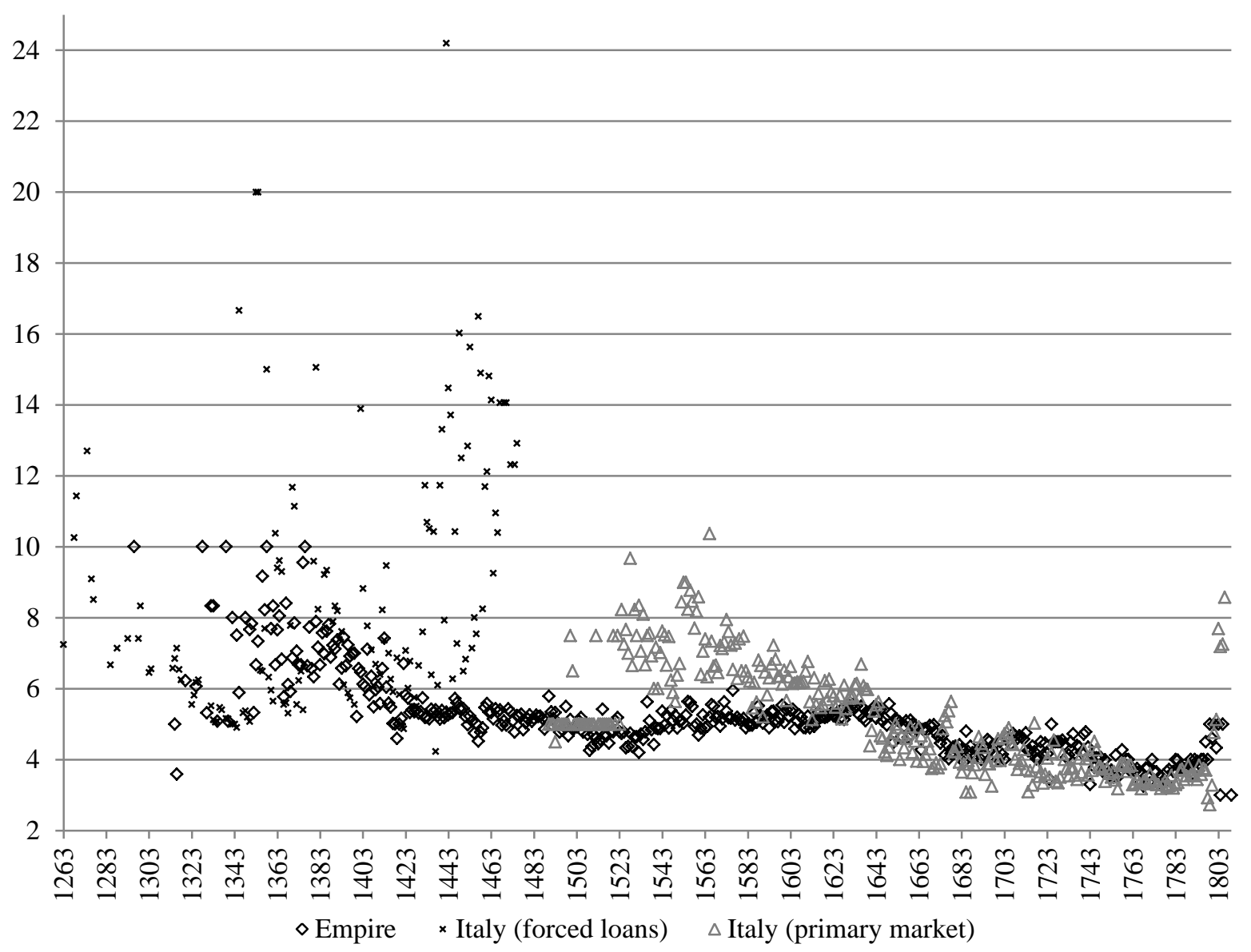

Sources: Online Appendix A. 
Figure 3: Capital market integration in Italy and the Empire: panel trends (logs of differentials around the mean)

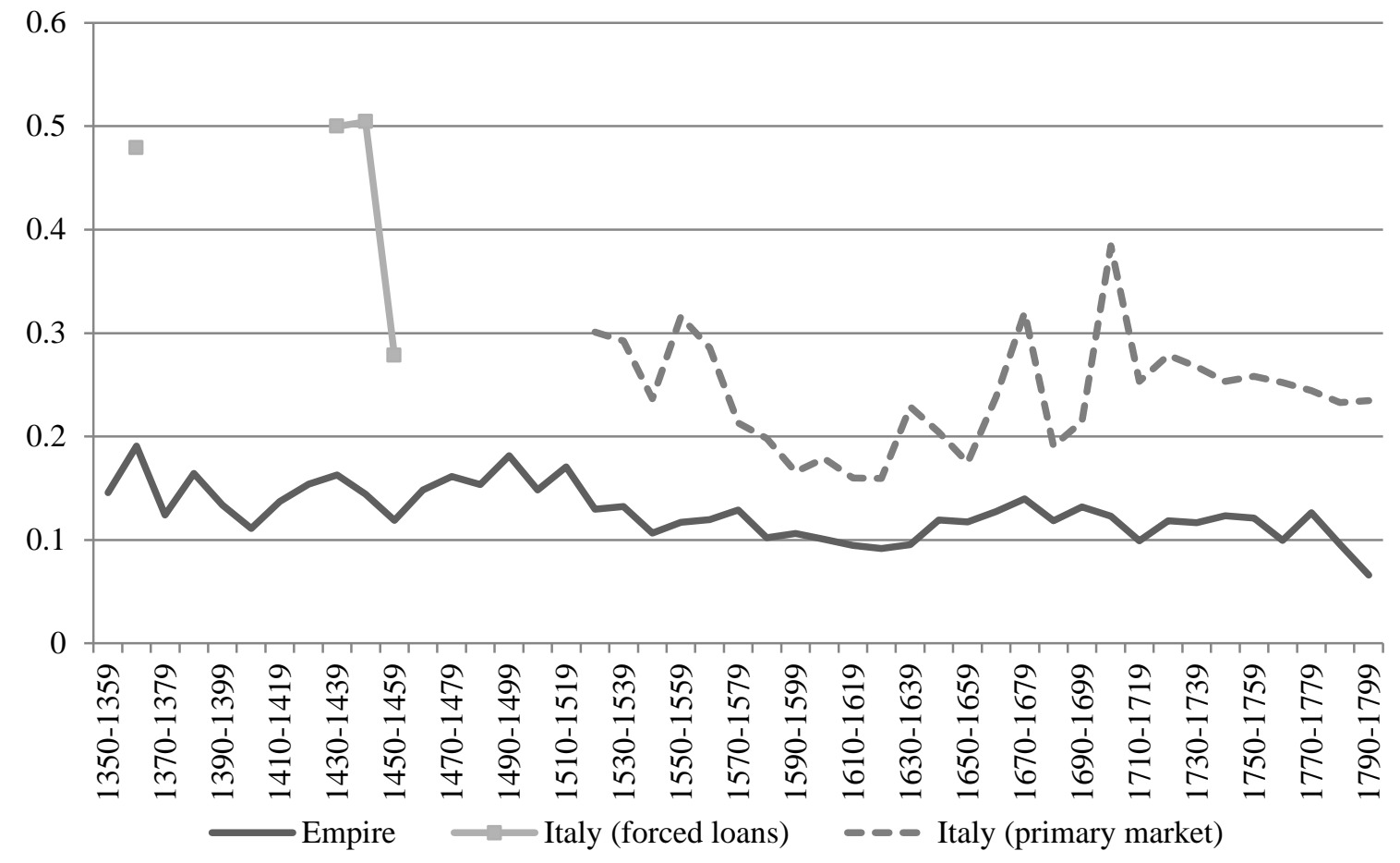

Sources: Online Appendix A.

Figure 4: Inter-city investment in the Empire: trends in distance (in kilometres) and capital (in consumption baskets) compared to interest differentials (inverted log ratio)

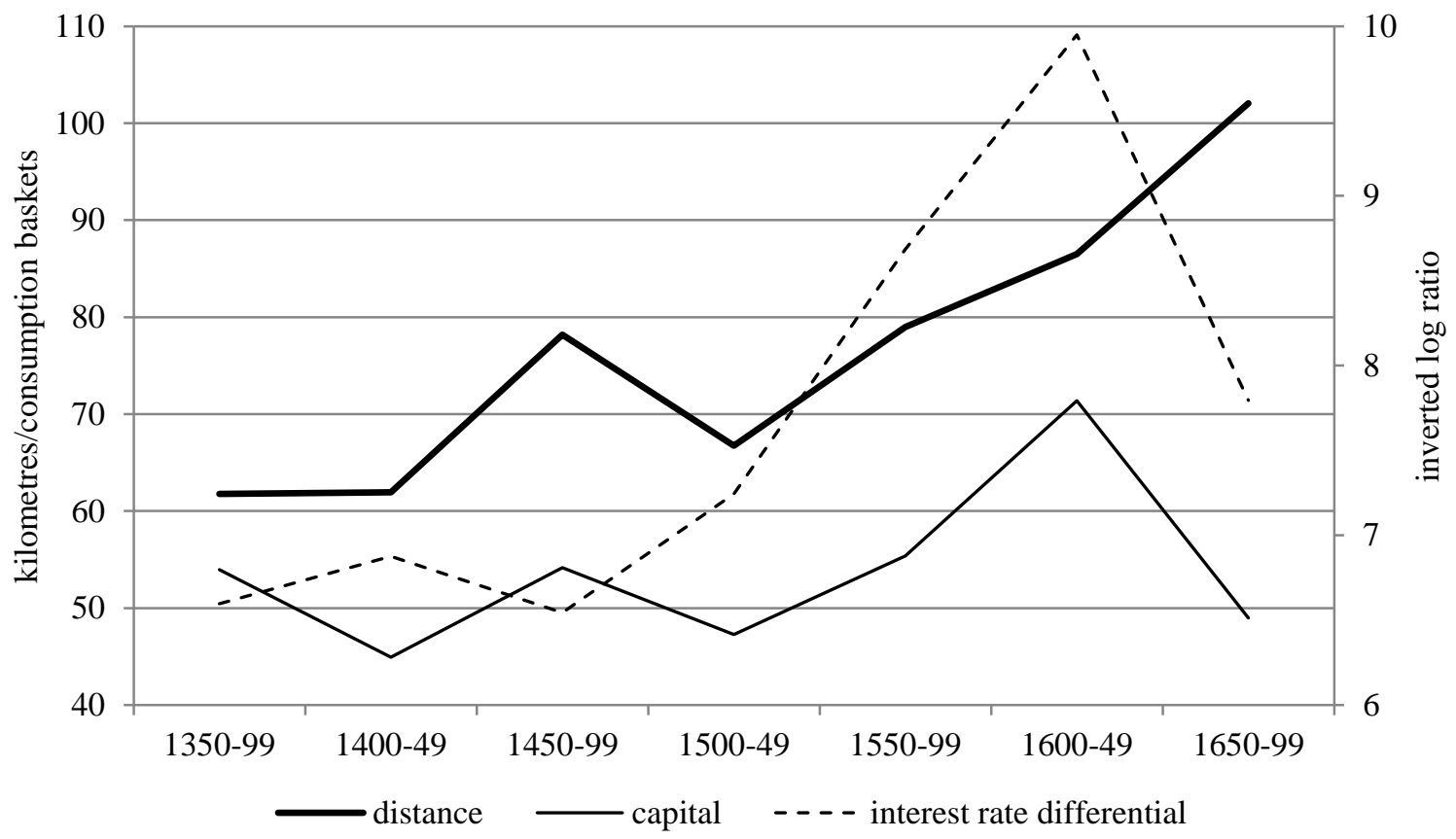

Sources: Online Appendix A. 
Figure 5: Pairwise differentials by distance in the Empire: panel trends (logs)

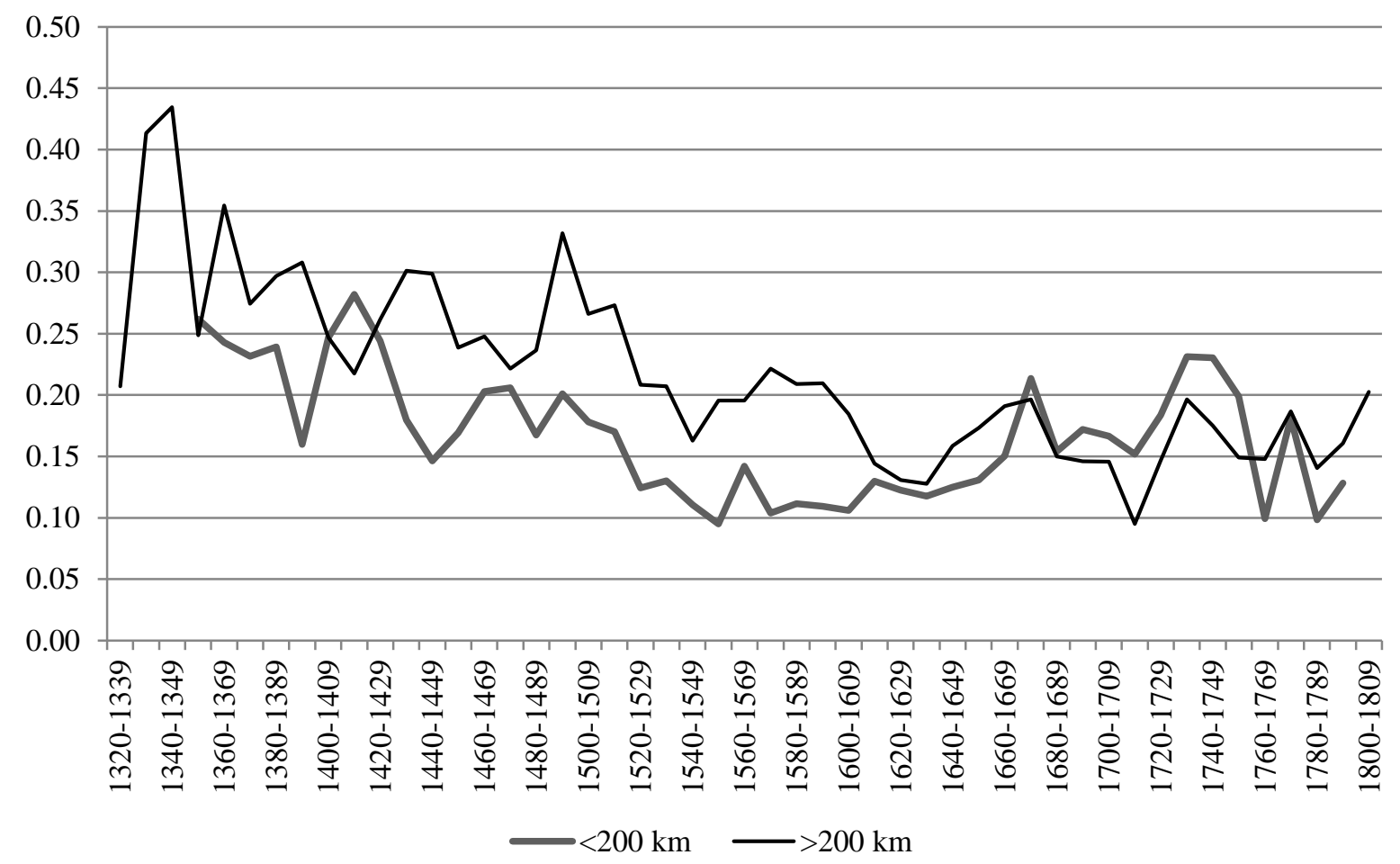

Sources: Online Appendix A. 
Figure 6: Capital market networks: clusters of cities
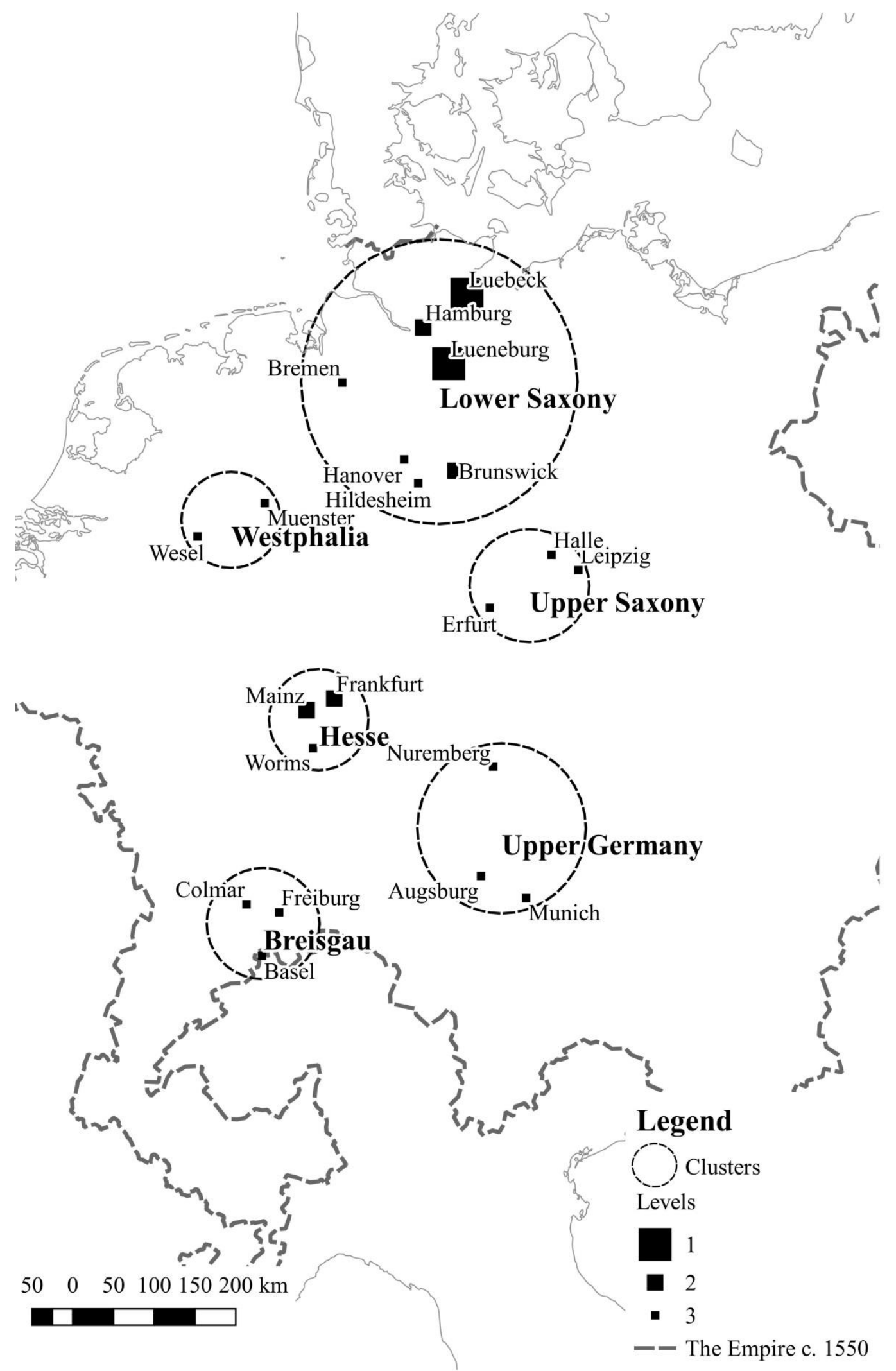

Sources: Online Appendix A. 
Figure B.1: Origins of foreign investors (12 cities sample)
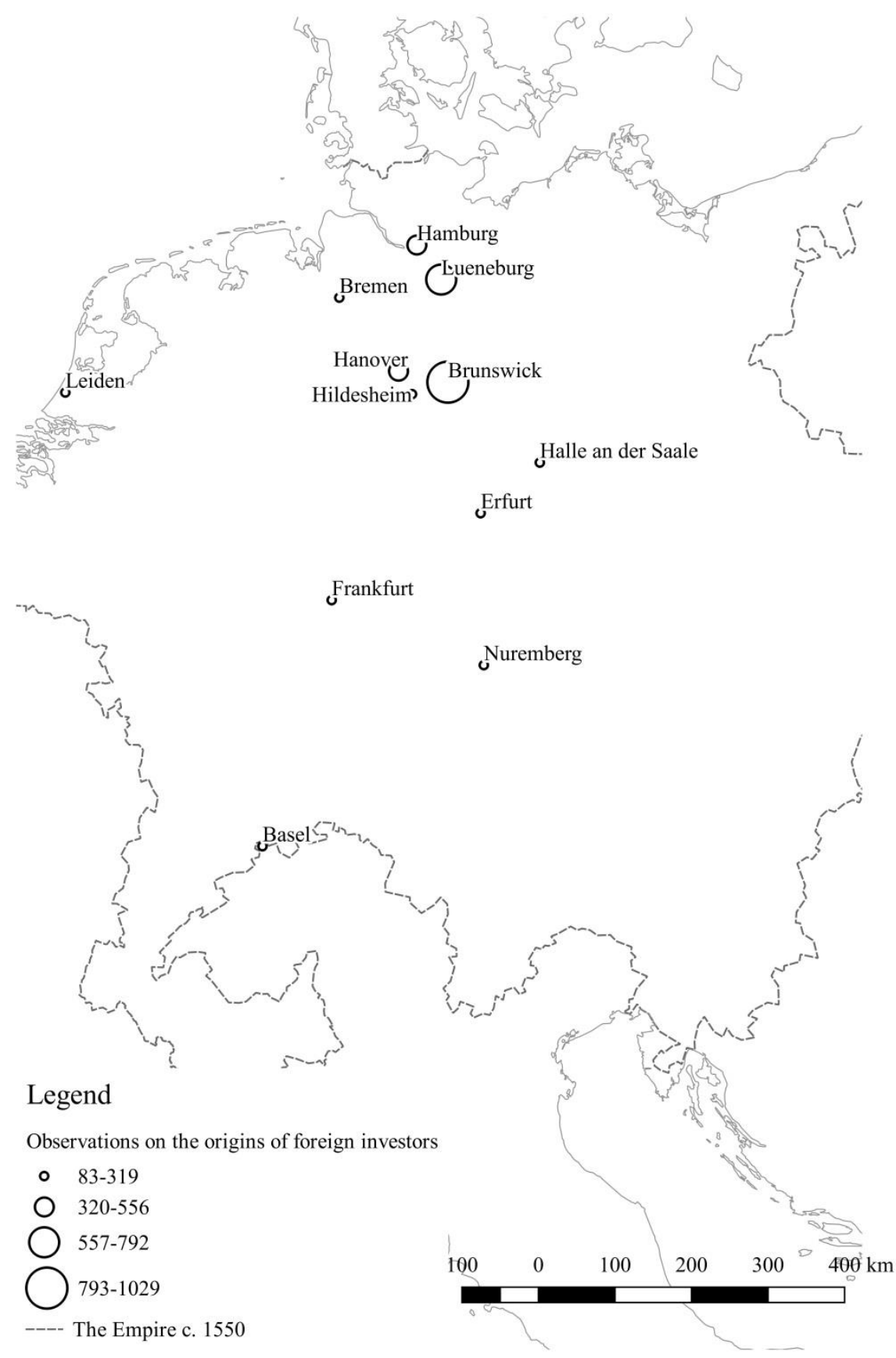

Sources: Online Appendix A. 
Figure C.1: Inter-city investment in the Empire: the distribution of distance and capital before and after 1520

a) Distance

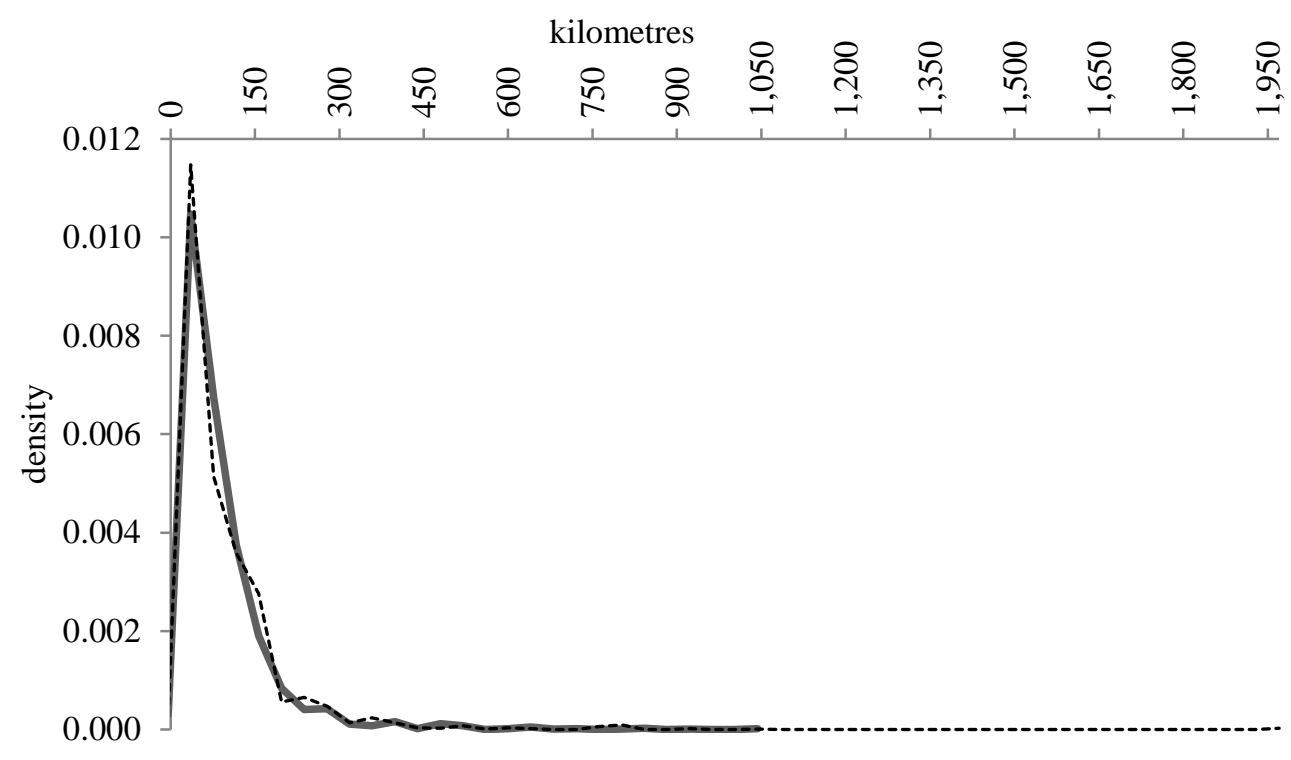

before $1520 \quad-------$ from 1520

b) Capital

consumption baskets

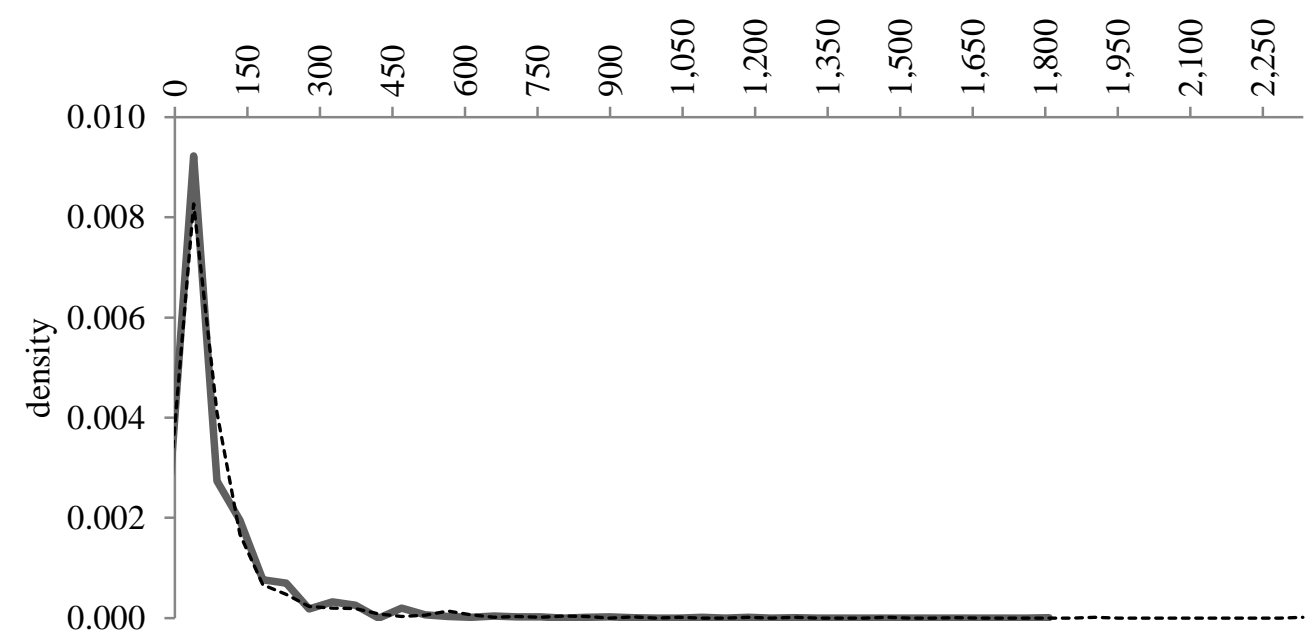

— before $1520 \quad-\cdots---\cdot-$ from 1520

Sources: Online Appendix A. 
Figure C.2: Integration between regions and the Empire as a whole: panel trends in dispersion around the mean $(\log s)$

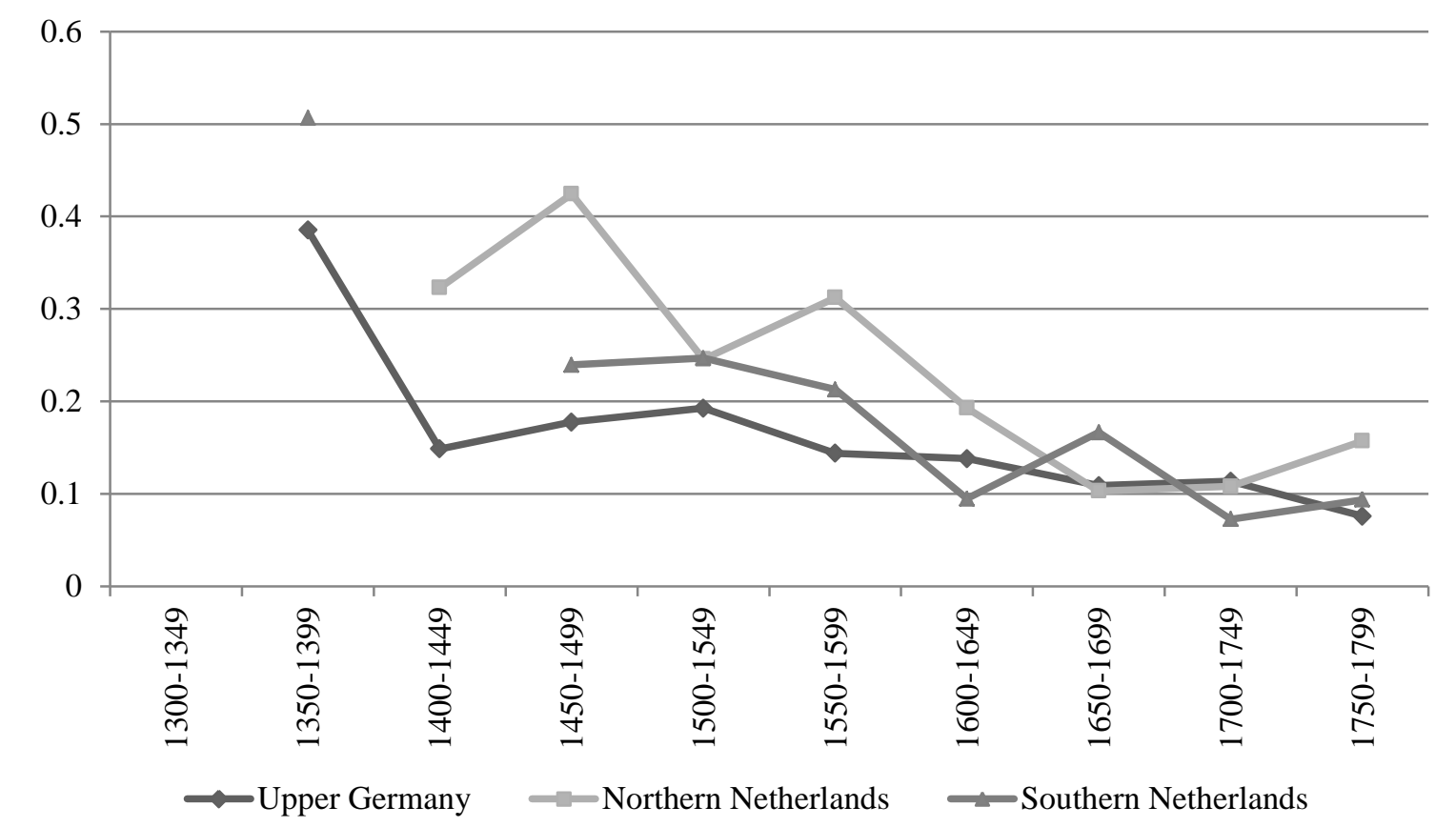

Sources: Online Appendix A.

1 Related studies that, however, draw on a small number of interest rate observations and/or markets are Victoria Bateman (2012, p. 120) and Cyril Milhaud (2016). Bateman looks at a few scattered differentials in the cost of capital across Genoa, the Low Countries, England and Germany that suggest capital markets had been fairly well integrated already by the fifteenth century. Milhaud examines 88 private annuity contracts drawn up in 1725 and 1735 in the kingdoms of Castile and Aragon. He finds little capital movement between these territories and argues that this was an outcome of legal fragmentation. Michele Fratianni (2006, pp. 498-504) argues that early modern Genoa was well-integrated with other Italian and European markets, but finds large yield differentials with Naples and Antwerp. Larry Neal's $(1985,1987,1994)$ analyses of capital 
market integration in the eighteenth and nineteenth centuries focus on stock market prices and the major financial centres of the period.

2 The term 'Empire' is used with reference to the Holy Roman Empire north of the Alps and, unless stated otherwise, includes also a few markets in eastern France close to the Empire's border (see Figures 1 and 2 below).

3 Differences were on average 0.28 percentage points at a time when average interest rate were about 5 per cent (see Figure 2). This result is based on the comparison of 23 yields from the same place and year on the primary and the secondary markets. Data from Nuremberg, Hanover and Münster (1412-1680). Hanover City Archives, NAB 8242, p. 127/3 \& 202/2, 441/1; Münster City Archives A IX 139 \& 392, 393 \& 395; State Archives Nuremberg, Bestand Losungsamt, vol. 69, fol. 66v, 80v, 81v, 91r, 133v, 217r, 219r, 220r, 222r; vol. 70, fol. 9r-v, 11r, 93v, 106r, 109r, 115v, 117r, 121r. On the development of secondary markets in late medieval Germany see Hans-Jörg Gilomen (1984, pp. 193-201).

4 This tallies with Alberto Feenstra (2014, pp. 15-16), who finds that for bonds issued by the Dutch province of Zeeland in the second half of the eighteenth century, the secondary market yields were very close to the official rates.

5 Focusing on official rates and the primary market implies not controlling for mark-ups for mostly local primary buyers, but this produces a similar bias against our results. Within early modern Italy there is fairly strong evidence of mark-ups in Venice and especially Genoa (cf. Chilosi 2014, pp. 909-10). However, in Genoa, not only were secondary prices unusually high, but also nominal rates were exceptionally low. Thus if we used secondary market yields, which do not include rents enjoyed by primary buyers, the differentials between Genoa and the other Italian cities would be even higher than those we observe.

6 To be clear, the data do not include commercial loans that may have been tied to commodity trade. We discuss a potential link between commodity trade and capital market integration below (p. 21).

7 Available at https://www.nuffield.ox.ac.uk/People/sites/Allen/SitePages/Biography.aspx (accessed $16 / 11 / 16)$. 
${ }^{8}$ When we could not precisely measure the difference, we excluded the relevant observations. In Nuremberg, the ratio of taxed over untaxed rates was stable at around 1:1.21 only between 1490 and 1500. In Brunswick, some life annuities were exempt from taxation and other civic burdens, but this had a negligible impact on interest rates.

9 The analysis is based on 12 cities with at least 80 observations on the origin of foreign investors; see map in Figure B.1, Online Appendix B. The network distance (the average number of links one needed to pass to reach another node) for the same sample is 1.6, after excluding Leiden which had only indirect links (through Amsterdam) with the main network. This number also signals a dense network: Most cities were connected either directly or through a third place.

10 While Chambery is beyond the Alps, it belonged to Savoy. Thus, the data for Chambery are used to investigate patterns of capital integration both in Italy and north of the Alps.

11 The results are robust to controlling for potential bias due to composition effects by including fixed effects. The rates paid on life annuitities show a similar pattern.

${ }^{12}$ Figure 3 draws on at least ten observations per decade as minimum threshold for inclusion. On average, 63 observations per decade are available.

13 A place is considered to belong to the hinterland of the closest other place that had at least 5000 inhabitants at some point in time during the period covered here (1228 to 1802). There are 670 observations referring to villages within the hinterlands of our cities; the average distance from the city is $20 \mathrm{~km}$; the maximum is 56 $\mathrm{km}$.

14 The consumption basket is based on price data from Strasbourg which are the most comprehensive of all price series available for the Empire (1326-1875). We used a smoothed trend obtained with an Epanechnikov kernel for the conversions. To avoid boundary problems, London price data have been used for extrapolating the series backwards to 1264 , the first year London prices are available for. Both the Strasbourg and the London price indices are from the Robert Allen (2001) database. 
As distances and volumes of inter-city investments are much more volatile than interest rate differentials, more observations are needed to produce reliable estimates, which is why 50 -years rather than 10 -years dummies are used here. For distance, there are only 18 means in 1700-1749 and 8 means in 1750-1799 as compared to 68 in 1650-1699 and 297 in 1550-1599.

16 The case of Augsburg illustrates the effects of the war on both the local supply of and demand for capital; see Bernd Roeck (1991, pp. 270-283).

17 There are 2,545 observations from before 1520 and 1,998 from the years thereafter.

18 For a graphical exposition, see Figure C.1, Online Appendix C.

19 To make good use of the available interest rates data, here and in the subsequent analysis we extrapolate missing years from the heritable annuities' series on the basis of the rates paid on life annuities in the same place at around the same time. Normalising yields on securities with different terms to maturity is standard practice in financial history (e.g. Flandreau and Flores 2009; Chilosi 2014). This is a a safe procedure for the data from around the mid-fifteenth century when pricing became systematic and less subject to idiosyncracy .In addition, we linearly interpolate missing observations when both the adjacent years are covered. Such interpolations are expected to be very precise, given that the series exhibit very little volatility. In these ways we augment the overall sample of yearly means by about 12 per cent. Reassuringly, the overall trends detected by the heritable annuity and the augmented samples are identical.

20 The cities not shown in the figure are Osnabrück, Soest, Schaffhausen, Memmingen, Vienna, Wismar and Würzburg.

${ }^{21}$ On the relationship between commodity trade and capital market integration see p. 23 below.

22 Node degree analysis also finds that capital markets were particularly developed in Lübeck (before 1520) and Hamburg (from 1520), even after econometrically controlling for sample bias.

23 The few available data on capital movements suggest only weak links between these regions as well as between them and the rest of the Empire. We therefore treat the cities in the Northern Netherlands as a cluster in its own right. Considering that clusters typically formed around important financial centres and 
that Antwerp and Bruges were such centres (e.g. Munro 2003, pp. 541-42), we define the Southern Netherlands, including the other cities in Brabant, Flanders and Northern France, as another cluster. 'Northern France' consists of Amiens, Arras, Douai, Lille, St. Quentin and Paris. All these cities except Paris were at some point ruled by Burgundy.

24 See Figure C.2, Online Appendix C, on the three clusters driving convergence.

25 Wheat markets, for example, were much better integrated in Italy than in Central Europe (Federico, Schulze and Volckart, mimeo 2018).

26 For example, on 14 March 1599 the Florentine Senate stated that 'buyers ... can be ... subjects as well as foreigners ... of whatever fate, grade or condition' (Archivio di Stato di Firenze, Monte Comune o delle Graticole, parte I, pezzo 3, p. 261).

27 Contemporaries noted the advantages of the Empire's constitutional arrangements. Thus, Edward Brown (1677, p. 65), an English physician travelling through Germany in 1668, argued that through the Imperial Diet 'the great Concerns of Germany are much secured, and their peace and quiet Established. Wherein Germany seems to have a better advantage than Italy; For Italy being likewise divided into many Dominions and Principalities, hath no common Diet or Great Council, whereby to proceed for their Publick safety: Which makes them often divided in their common Concerns...'

28 Staatsarchiv Nürnberg, Bestand Losungsamt Vol. 69, fol. 21 r (no.117), 26 v (no. 136), 28r (no. 137), Stadtarchiv Hannover, NAB 7228, fol. 19 v; Zuijderduijn (2009, pp. 113-15).

29 Regionaal Archief Dordrecht (formerly ,Gemeente Archiev Dordrecht'), GAD 1, no. 434, fol. 50v-53r, Stadtarchiv Braunschweig, B I 11 Leibgedingebücher, vol. 4, fol. 36v-39r), Stadtarchiv Hannover, NAB 8242, Stadtobligationsbuch 1387-1533, 108/2, 110/1, 118/12, 130/1, 137/3, 140/2, 141/4,156/1, 163/2, $164 / 2,177 / 1,184 / 1,192 / 1,197 / 1,227 / 3,267 / 2,268 / 1,275 / 1,284 / 1,287 / 2,364 / 2,434 / 1,437 / 2,542 / 2$, 554/2, 571/2, 755/1; NAB Nr. 7228 p.2; Urkunden Abteilung 3 - Schuldurkunden des Rates, nos. 43, 46, 51, $55,56,57,60,132,172,248,269,275,293,298,307,309,310,314,315,317,318,321,323,334,340$, 
342, 346, 347, 350, 354, 357, 358, 361, 363, 366, 367, 373, 537, Albers (1930, pp. 49-50), Zuijderduijn (2009, p. 115).

30 Stadtarchiv Hannover, NAB 8242, Stadtobligationsbuch (1387-1533), 118/12; Abteilung 3 -

Schuldurkunden des Rates nos. 43, 46, 51, 57; Staatsarchiv Nürnberg, Bestand: Losungsamt, vol. 69, fol. 97r-v (no. 444), 98r (no. 447), 99r (no. 450), 103r (no. 468), 112r (nos. 499-500), 126r (no. 567); vol. 70, fol. 125r (no. 386); Stadtarchiv Erfurt, 1-1/21 10 Libri ordinationum, vol. 1, fol. 1v, 8v; 1-1/21-12/1 Obligationen, 70ff, 75ff, 147ff; 1-1/22, 2 Hauptrechnungen no. 1, 0-1/ 4- 121 (1); Stadtarchiv Lüneburg, AB 55 Kopie von Rentenbriefen (1441-1492), fol. 20r, 76r f., 90r, 93r-94r, 98v f; Landeshauptarchiv Magdeburg, Copiar der Obligationen der Stadt Halle, Cop. 395a,fol. 27v, 29v, 38v, 315r; Cop. 396, fol. 30r, 131r, 134v, 159r; Klinger (2011, pp. 336-38); Archives de la ville Strasbourg, Série IV No. 71, p. 148; Stadtarchiv Münster, Ratsarchiv A IX, Findbuch zu den Rentenverschreibungen aus Abt. A IX des, Alten Archivs', no. 43. 